\title{
Electronic clinic journaling: The use of weblogs to support evidence -based practice in doctor of audiology students
}

\author{
Gayle B. Neldon \\ West Virginia University
}

Follow this and additional works at: https://researchrepository.wvu.edu/etd

\section{Recommended Citation}

Neldon, Gayle B., "Electronic clinic journaling: The use of weblogs to support evidence -based practice in doctor of audiology students" (2009). Graduate Theses, Dissertations, and Problem Reports. 3489.

https://researchrepository.wvu.edu/etd/3489

This Dissertation is protected by copyright and/or related rights. It has been brought to you by the The Research Repository @ WVU with permission from the rights-holder(s). You are free to use this Dissertation in any way that is permitted by the copyright and related rights legislation that applies to your use. For other uses you must obtain permission from the rights-holder(s) directly, unless additional rights are indicated by a Creative Commons license in the record and/ or on the work itself. This Dissertation has been accepted for inclusion in WVU Graduate Theses, Dissertations, and Problem Reports collection by an authorized administrator of The Research Repository @ WVU.

For more information, please contact researchrepository@mail.wvu.edu. 
Electronic Clinic Journaling: The Use of Weblogs to Support Evidence-Based Practice in Doctor of Audiology Students

Gayle B. Neldon, MS

Dissertation submitted to the
College of Human Resources and Education
at West Virginia University
in partial fulfillment of the requirements
for the degree of
Doctor of Education
in
Technology Education

Neal Shambaugh, Ph.D., Chair

David McCrory, Ph.D.

Dennis Ruscello, Ph.D.

Sebastian Diaz, Ph.D.

Gary Harris, Ph.D.

Department of Technology, Learning, and Culture

Morgantown, West Virginia

2009

Keywords: Evidence-based practice, Weblogs, Audiology, Clinical Practicum

Copyright 2009 Gayle B. Neldon 


\section{ABSTRACT \\ Electronic Clinic Journaling: The Use of Weblogs to Support Evidence-Based Practice in Doctor of Audiology Students}

Gayle B. Neldon

Evidence-based practice (EBP) is a strategy for the provision of high quality health care. The use of journals to document clinical experiences and reflection has been used in speech-language pathology as well as nursing and psychology. This study uses qualitative analysis to study what AuD students learn about evidence-based practice from writing and reading clinic Weblogs, as well as to investigate AuD students' reactions to writing and reading these Weblogs and evidence-based practice as they have experienced it. The value of sharing evidence supporting clinical practice via electronic clinic journals in the form of Weblogs among peers was explored. Analysis of Weblog content during the study period suggested that students learned very little about evidence based practice. However, interview data from students who had participated in the Weblog assignment indicated that students believed that they learned to find evidence to support clinical practices, could discuss evidence, and improved their abilities to consume research literature. Recommendations for modeling evidence-based practice and teaching students to read and understand research literature were made. 


\section{DEDICATION}

The author wishes to dedicate this work to the following people:

Gary, Kristin, and Andrew, for your love and support.

Mom and Dad, for giving me the heritage and value of an education. 


\section{ACKNOWLEDGEMENTS}

The author wishes to acknowledge the following people for their help making this goal a reality:

Neal Shambaugh, PhD, my advisor, for all his guidance, advice, and timely prompts. Thank you for helping me finish what I started.

Dennis Ruscello, $\mathrm{PhD}$, my friend, colleague, and committee member. I appreciate your confidence in me.

David McCrory, PhD, Sebastian Diaz, PhD, and Gary Harris, PhD, my committee members.

Thank you for your commitment over the long haul and for working so well around your schedules to meet with me.

John Oughton, EdD, for helping me wrestle Excel into submission.

Dick Walls, PhD, for being my number one cheerleader.

Cheryl Prichard, EdD, for your friendship and wise advice.

Lynn Cartwright, EdD, for your support and for letting me cry on your shoulder.

My friends, who faithfully asked after my progress and excused my disappearances.

My students, for your enthusiasm and support. 


\section{TABLE OF CONTENTS}

Abstract............................................................................

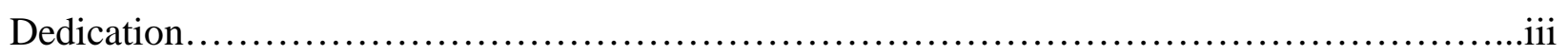

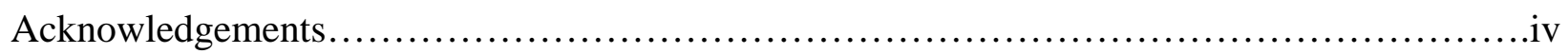

Table of contents..................................................................

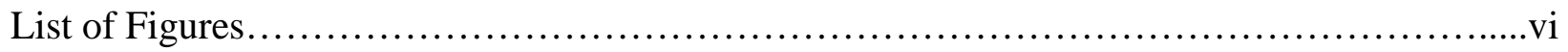

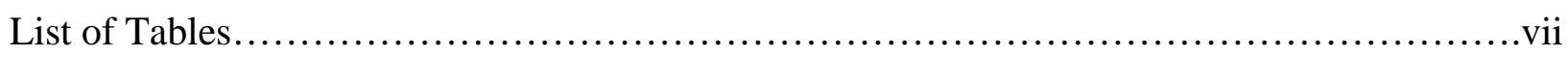

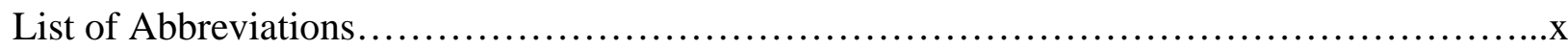

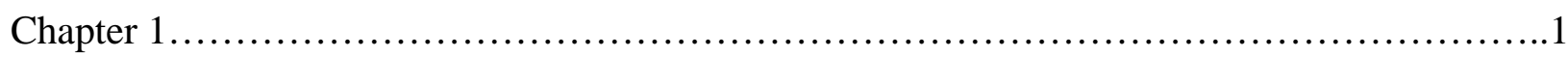

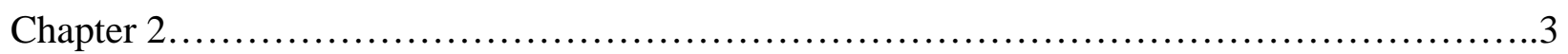

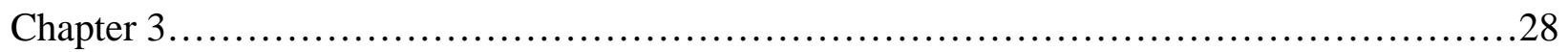

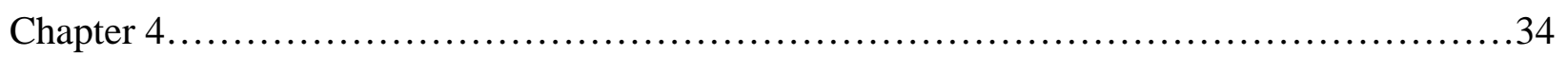

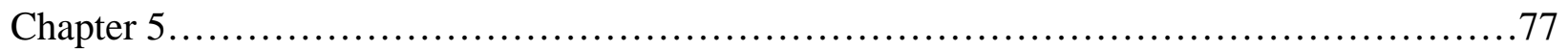

References...................................................................94

Appendix A.................................................................... 100

Appendix B................................................................ 109

Appendix C.......................................................................

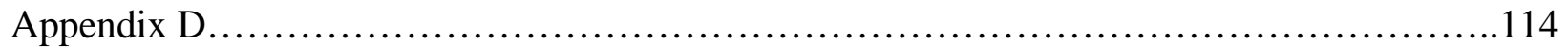

Appendix E.......................................................................

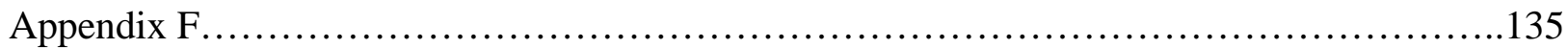




\section{LIST OF FIGURES}

Figure 1. Levels of Evidence......................................................9

Figure 2. Knowledge management pyramid.........................................15

Figure 3. RQ2 survey means results...............................................53

Figure 4. I learned from the Weblog assignment.........................................54

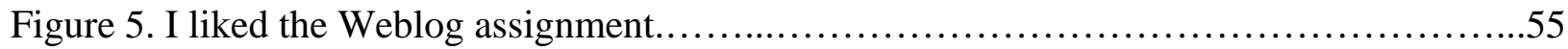

Figure 6. RQ3 survey means results. ..........................................67

Figure 7. Needed more clinical practicum exposure to EBP.............................68

Figure 8. Needed more graduate course EBP exposure ..................................69

Figure 9. I learned very little EBP in clinical practicum ................................. 70

Figure 10. Substantial time devoted to EBP in clinical practicum.........................71

Figure 11. I learned quite a lot about EBP in my AuD courses ............................72

Figure 12. Substantial time devoted to EBP in AuD courses..............................73

Figure 13. I frequently read other AuD evidence posted...................................74

Figure 14. Clinical knowledge management pyramid...................................84 


\section{LIST OF TABLES}

Table 1. Study Participants in Relation to All Current AuD Students.........................29

Table 2. RQ1: All Blog Data EBP Predominant Categories and Frequency Counts.............34

Table 3. RQ1. Select Quotes From Blog Content EBP Predominant Categories................ 36

Table 4. RQ1: Predominant KASA Skills Standards Categories and Corresponding

Frequency Counts................................................... 37

Table 5. RQ1A: Defining “Evidence-Based Practice” Categories, Frequency Counts, \&

Select Quotes......................................................38

Table 6. RQ1B. Purpose of EBP Categories, Frequency Counts, \& Select Quotes...............39

Table 7. RQ1C: Benefits from Weblogs Categories, Frequency Counts, \& Select Quotes.......40

Table 8. RQ1D: Benefits from EBP in Weblogs Categories, Frequency Counts, \& Select

Quotes...........................................................4 41

Table 9. RQ1E: Barriers to Writing Weblogs Categories, Frequency Counts, \& Select

Quotes

Table 10. RQ1F: Barriers to Reading Weblogs Categories, Frequency Counts, \& Select

Quotes

Table 11. RQ1G: Practices Learned Writing Weblogs Categories, Frequency Counts \&

Select Quotes..........................................................44

Table 12. RQ1H: Practices Learned Reading Weblogs Categories, Frequency Counts, \&

Select Quotes.....................................................45

Table 13. RQ2A: Initial Reactions to Weblog Assignment Categories, Frequency Counts, \&

Select Quotes.....................................................47 
Table 14. RQ2B: Change of Opinion Over Time Categories, Frequency Counts, \& Select

Quotes....

Table 15. RQ2C: Favorite Aspect of the Blog Assignment Categories, Frequency Counts, \&

Select Quotes.

Table 16. RQ2D: Least Favorite Aspect of the Assignment Categories, Frequency Counts, \&

Select Quotes.

Table 17. RQ2E: Recommendations For Blog Assignment Categories, Frequency Counts, \&

Select Quotes.

Table 18. RQ2F: Other Blog Assignment Comments Categories, Frequency Counts, \&

Select Quotes.

Table 19. RQ3A: EBP Learning From Courses Categories, Frequency Counts \& Select

Quotes. .56

Table 20. RQ3B: Learned EBP From Blog Assignment Categories, Frequency Counts \&

Select Quotes.

Table 21. RQ3C: Evidence-Based Practice Readings Categories, Frequency Counts \&

Select Quotes.

Table 22. RQ3D: Specific Evidence Saved Categories, Frequency Counts \& Select Quotes.....59

Table 23. RQ3E: Thoughts of Implementing EBP Categories, Frequency Counts \&

Select Quotes.

Table 24. RQ3F: Teaching EBP in AuD Programs Categories, Frequency Counts \& Select

Quotes.....

Table 25. RQ3G: Teaching EBP in WVU's AuD Program Categories, Frequency Counts \&

Select Quotes 
Table 26. RQ3H: Recommendations for EBP in Weblogs Categories, Frequency Counts \&

Select Quotes.

Table 27. RQ3I: More Course Exposure to EBP Categories, Frequency Counts \&

Select Quotes.

.64

Table 28. RQ3J: More Clinic Practicum Exposure to EBP Categories, Frequency Counts \&

Select Quotes.......................................................65

Table 29. RQ3K: Other EBP Comments Categories, Frequency Counts \& Select Quotes.......66

Table 30. RQ1: All Blog Data EBP Categories and Frequency Counts.......................114

Table 31. RQ1: Quotes from Blog Content EBP Categories.................................114

Table 32. RQ1: General KASA Skills Standards Categories and Corresponding Frequency

Counts................................................................

Table 33. RQ1: Standard KASA Skills and Frequency..................................118

Table 34. RQ1: Learned About EBP Categories, and Frequency Counts......................121

Table 35. RQ1: Select Quotes From Learned about EBP Categories........................122

Table 36. RQ2: Reactions to Weblogs Interview Categories and Frequency Counts............128

Table 37. RQ2: Select Quotes From Weblog reactions Categories.........................129

Table 38. RQ3: Reactions to Evidence-Based Practice Interview Categories and Frequency

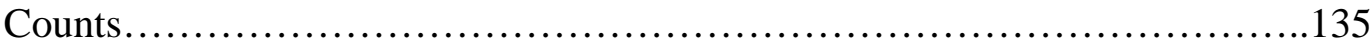

Table 39. RQ3: Select Quotes From Reactions to Evidence-Based Practice Interview

Categories......................................................... 138 


\section{LIST OF ABBREVIATIONS}

\begin{tabular}{ll} 
ASHA & American Speech-Language-Hearing Association \\
AuD & Doctor of Audiology \\
CPGs & Compact disc \\
CSD & Clinical Practice Guidelines \\
EBM & Communication sciences and disorders \\
EBP & Evidence-based medicine \\
EMRs & Evidence-based practice \\
KASA & Electronic medical records \\
MAC OS X & Knowledge And Skills Acquisition form \\
PICO & Macintosh Operating System Ten \\
& Patient population or problem; Intervention or area of interest; \\
TAMS Analyzer@ & Text Analysis Markup System Analyzer@ \\
URL & Uniform resource locator \\
TAMS & Comparison intervention (if the study compared group differences) or \\
RQ1 & Research Question 1 \\
RQ2 & Research Question 2 \\
RQ3 & Research Question 3 \\
Rtf & Rich text format \\
\hline
\end{tabular}


CHAPTER 1

Introduction

Evidence-based practice and informatics are complementary fields in healthcare that have been developed and facilitated by the introduction and growth of Internet technologies in the workplace. By finding and applying the best available evidence, or research, to support clinical decision-making in medicine, nursing, and other allied health profession, clinicians can provide their patients with high quality healthcare. While patient values and clinical expertise were originally omitted from working definitions of evidence-based practice, they have recently been included to consider the patients’ preferences. Informatics, specifically healthcare informatics, makes evidence-based practice a feasible reality by providing data and information management to create and support knowledge.

The use of clinic journals to document practicum experiences is not new to speechlanguage pathology and audiology. As the hearing clinic coordinator for the West Virginia University Department of Speech Pathology and Audiology, I assigned weekly clinic Weblog (or blog) activities to Doctor of Audiology (AuD) graduate students in August, 2005 and have continued to make such assignments for clinic every semester since, including summer clinic session. The original Weblog assignment did not include an evidence-based practice component, but it has been added to the assignment beginning Fall, 2006. I have heard positive and negative comments from AuD students about the blogging activity. Some have said that they like to read the blogs written by other students. Others have said that they forget to write their blogs, or that they don't have time to do it.

As a clinic supervisor and the hearing clinic coordinator, I have gained insight into what kinds of clinical experiences the students are getting at outside placements and the clinical 
competencies that students meet at specific placements by reading their blogs. AuD students have commented to me regarding specific other students' blogs that they enjoy reading. They have also said that they are interested in being placed in specific practicum sites based on what they have read in clinic blogs.

The purpose of this study was to investigate what AuD students learn about evidencebased practice from writing and reading clinic Weblogs, as well as to investigate AuD students' reactions to writing and reading these Weblogs and evidence-based practice as they have experienced it. 


\section{CHAPTER 2}

Literature Review

\section{Background}

Evidence-based practice. Evidence-based practice (EBP) is a strategy for the provision of high quality health care, based on the roots of the strategy in medicine. Evidence-based medicine (EBM) has been defined as "the integration of best research evidence with our clinical expertise and our patient's unique patient’s values and circumstances” (Sackett, Straus, Richardson, Glaziou \& Haynes, 2000, p. 1). This practice has been adopted in several allied health professions including nursing, physical therapy, occupational therapy, speech-language pathology, and audiology. Sackett, Rosenberg, Gray, Haynes, and Richardson (1996) state that philosophically, the practice dates back to the mid $19^{\text {th }}$ century in Paris and earlier elsewhere. In 2004, the American Speech-Language-Hearing Association (ASHA) published a technical report aimed at informing its members of the principles of EBP and recommending an increase in quantity of evidence to support the professions (American Speech-Language-Hearing Association, 2004). This document presents an overview of EBP along with a discussion of the rating of research for quality and credibility. The document also includes a statement that the research mission of the association supports EBP. The following year, ASHA published a position statement indicating, “audiologists and speech-language pathologists incorporate the principles of evidence-based practice in clinical decision making to provide high quality clinical care” (American Speech-Language-Hearing Association, 2005, p. 1). This position statement provides further direction in evaluating the quality of evidence and reaffirmed the role of EBP in the research mission of the association. Johnson (2006) advocates that communication disorders professionals develop a "show me the data” approach to clinical problems. 
The American Academy of Audiology is another audiology professional organization that has begun to recognize the role of EBP in clinical practice. The July 2005 issue of The Journal of the American Academy of Audiology is devoted to the topic of EBP, including a tutorial as well as systematic reviews and well-designed random controlled empirical studies yielding evidence for designated clinical populations related to hearing habilitation. This issue provides a foundation of evidence-based practice for the audiologist. More recently, the Academy has published Clinical Practice Guidelines (CPGs) that include strategies for adoption into EBP (Loavenbruck, Ricketts, Solodar, \& Sweetow, 2006 and Chisolm, Johnson, Danhauer, Portz, Abrams, Lesner, McCarthy, \& Newman, 2007).

Purpose of EBP. The fundamental goal of evidence-based practice is excellent clinical decision-making based on the best evidence available. Such decisions are expected to result in high quality health care. Cope (2003) states, "rising costs in healthcare and limited healthcare resources have created a demand for cost-effective, beneficial patient care ” (p. 97). She indicates that EBP can lead to such an end in nursing. A look back over the history of medicine reveals numerous early practices that were later discontinued after scientific study indicated that those practices were ineffective, or worse, dangerous. One such practice was the belief that premature newborns should be placed in oxygenated isolates to prevent retrolental fibroplasias. Research later revealed that this practice actually contributed to vision disorders and blindness. Other historical medical practices that have since been proven to be ineffective include bloodletting and leaches. As knowledge continues to increase, it can be speculated that some current medical and healthcare practices may be shown to be ineffective or insufficient.

EBP principles. Johnson (2006) suggests that relevant evidence comes from "valid results of clinically oriented, primary studies published in peer-reviewed journals, or when available, 
from systematic reviews that provide comprehensive, rigorous syntheses of the results of primary studies on a particular issue " (p. 21). However, a methodical approach to the literature must be taken in order to address specific clinical concerns. Therefore, several steps have been described which lead the clinician through the evidence-based practice process.

Generally, EBP/EBM consists of five steps described by Straus, Richardson, Glasziou, and Haynes (2005) as follows:

Step 1: converting the need for information (about prevention, diagnosis, prognosis, therapy, causation, etc.) into an answerable question.

Step 2: tracking down the best evidence with which to answer that question.

Step 3: critically appraising that evidence for its validity (closeness to the truth), impact (size of the effect), and applicability (usefulness in our clinical practice).

Step 4: integrating the critical appraisal with our clinical expertise and with our patient's unique biology, values, and circumstances.

Step 5: evaluating our effectiveness and efficiency in executing steps 1-4 and seeking ways to improve them both for next time (p. 3).

Cope (2003, p. 97) has designated additional steps including "identifying information necessary to solve the problem" and "developing and implementing clinical guidelines or protocols." According to Timio and Antiseri, as cited in Dale (2006), the purpose of EBP is to "shift medical decision-making away from the intuitive, authoritative, and subjective towards the scientific and objective” (p. 41). After reviewing the application of EBP in the realm of healthcare in general, Dale asserts that defined principles for EBP must be broad enough for application for any healthcare profession. She further states that all members of a multidisciplinary team must be committed to EBP if it is to be applied successfully. Georgio (2001) comments, "advances in 
information technology have spurred the development of EBM, as well as providing the very basis for its realization” (p. 127). A study by Johnson, Leung, Fielding, Tin, and Ho (2003) in Hong Kong found that undergraduate students were familiar with, and used, EBP regularly. Further, students indicated that they felt they needed new evidence weekly.

The discussion on the steps of EBP that follows is meant to provide the reader with an overview of the principles involved in the process. Numerous resources are available to provide "how to" information for the reader who is interested in learning how to implement EBP into clinical practice (see Bennet and Bennet, 2000, Cope, 2003, Johnson, 2006, and Straus, et al., 2000). Additionally, the Journal of the American Medical Association presented a series of regular articles under the heading "Users' Guides to the Medical Literature” which addressed specific steps and strategies for implementing EBM. Finally, EBM can trace its roots to the early 1980’s at McMaster University in Hamilton, Ontario and Oxford University in the United Kingdom. The British Medical Journal has published extensive articles from faculty and researchers at these two institutions, which will guide the reader through the development of EBM/EBP principles since that time.

Formulation of the question. Procedurally, EBP involves developing a question based on a client/case seen, typically at the time of the appointment, and evaluating research that supports or suggests a proven method or strategy for treatment of the case. Formulating a question that can be answered by the evidence is considered by many to be the first step. This is often the most difficult step of the process because the evidence available depends heavily on the search parameters. Straus, et al. (2000) indicate that the question posed must be answerable. Otherwise, the study findings may not apply to the specific case in question. Melnyk and Fineout-Overhold 
(2002) and Johnson (2006) use the mnemonic device, PICO, to format the questions. Following are the PICO guidelines:

- P - Patient Population or Problem

- I - Intervention or Area of Interest

- C - Comparison intervention (if the study compared group differences) or comparison status

- O - Outcomes

Once the question is formed, the clinician searches relevant databases for research studies that provide conclusions, implications, and recommendations for intervention. Ideally, the clinician would search for evidence in the time between assessment of the client/patient and making a decision on intervention/treatment. In medicine and audiology, that may mean excusing ones self from the exam room and accessing databases for evidence. This can be timely - one of the primary barriers to EBP, according to Thompson, McCaughan, Cullum, Sheldon, and Raynor (2005).

Access to evidence. Audiology professionals maintain membership in at least one of a number of professional organizations. Most of these associations regularly publish peer-reviewed research findings from among their membership. Access to this research is readily available to the clinician in print and electronic format as long as they maintain membership. However, membership in multiple organizations quickly becomes expensive and professionals often must decide among organization based on where their professional needs are best served. In such cases, the professional may then turn elsewhere. Georgiou (2002) points out that significant advances in information technology have facilitated the growth and development of evidence- 
based practice through access to electronic resources. With the advent of the Internet, access to research literature through electronic databases has become more convenient.

A number of databases exist which allows the clinician to search for peer-reviewed articles of empirical research by focusing on key words. Access to some databases can be limited, especially outside of university environments. Two popular databases for audiology include PubMed and ComDisDome. Unless the facility subscribes to the databases, retrieval of the actual study may require purchase. In many cases, the study abstract can be accessed. Questions remain about the amount of evidence that can be pulled from an abstract vs. the full document. Obviously, the full document is desirable. Other databases that may yield evidence for the audiologist include Medline, PsycINFO, and Education Resource Information Center (ERIC).

Critical appraisal of the evidence. Evaluation of the research findings based on rigor and study design is a critical component to EBP. This appraisal of the evidence must include attention to validity of the findings and relevance to the question posed, i.e., the specific client for whom evidence is sought. The focus of the appraisal is on design of the study design and the subject population. The World Wide Web offers more than quality research findings - a plethora of opinions and first-person stories are readily available by entering the same key words into any Internet search engine. Therefore, EBP experts have developed a criterion for evaluating the credibility of information. This criterion is referred to as "levels of evidence." A higher level of evidence is assigned to findings arising from meta-analyses and randomized controlled studies. Originally, EBM was based solely on empirical research findings. More recently, EBP proponents have included expert opinion and patient values among the applicable sources of evidence. However, the lowest level of evidence is assigned to these opinions. 
Levels of evidence defined. ASHA's Technical Report on EBP (2004) addresses the levels of evidence accessed and is similar to the levels of evidence held by other health care professions. The categorization of levels helps practitioners and researchers recognize the type(s) of research being cited as evidence. For example, a well-designed random-controlled study design is held as a more valid, and therefore more appropriate for generalization, than an expert's opinion. However, expert opinion should not be completely discounted, particularly in the absence of other empirical findings. The table below illustrates ASHA's levels of evidence: Figure 1. Levels of evidence.

\begin{tabular}{|l|l|}
\hline $\begin{array}{l}\text { Levels of evidence for studies of treatment efficacy, ranked according to quality and } \\
\text { credibility from highest/most credible (1a) to lowest/least credible (IV), adopted from the } \\
\text { Scottish Intercollegiate Guideline Network (www.sign.ac.uk). }\end{array}$ \\
\hline Level & Description \\
\hline Ia & Well-designed meta-analysis of >1 randomized controlled trial \\
\hline Ib & Well-designed randomized controlled study \\
\hline IIa & Well-designed controlled study without randomization \\
\hline IIb & Well-designed quasi-experimental study \\
\hline III & Well-designed correlational studies, i.e., correlational and case studies \\
\hline IV & $\begin{array}{l}\text { Expert committee report, consensus conference, clinical experience of } \\
\text { respected authorities }\end{array}$ \\
\hline $\begin{array}{l}\text { Reprinted with permission from Evidence-Based Practice in Communication Disorders: An } \\
\text { Introduction [Technical Report]. Available from www.asha.org/policy. C) Copyright } 2004\end{array}$ \\
American Speech-Language-Hearing Association.
\end{tabular}

Integrate evidence with clinical expertise and client values. When applying the evidence to an individual client, the clinician is cautioned to include the client into the decision-making process. Careful attention to the client's emotional, social, and financial status is encouraged by Guyatt, Haynes, Jaeschke, Cook, Green, Naylor, Wilson, and Richardson (2000). In fact, the authors state that the clinician may need to "trade off the benefits and risks” (p. 1291) of management strategies when considering the patient's values. For the audiologist, the evidence 
may recommend advanced amplification features to address the client's listening demands, however financial concerns may prohibit such technology. The audiologist may find it necessary to select a different model that will provide benefit in many, if not all, of the client's listening environments and remain affordable.

Evaluate the effects of acting on the evidence. Outcome measures are an important feature in the field of audiology, often associated with reimbursement issues. Clinicians are generally experienced at documenting benefits or the lack thereof for treatment options, such as fitting amplification devices or conducting auditory habilitation for a child with a cochlear implant. When implementing EBP, it is imperative to assess the outcomes of the clinical decisions that have been made based on best available evidence. Should application of the evidence be deemed effective, the clinician is prepared to consider the same application for the next client who fits the subject profile. On the other hand, a negative outcome should cause the clinician to reassess the homogeneity of the client and the subject profile, or perhaps refine the original question and begin the search for evidence again. Johnson (2006) suggests that clinicians determine what outcome measures are appropriate for the individual client and revisit the clinical decision-making process if the anticipated outcomes are not observed.

With the move to the Doctor of Audiology (AuD) degree as the entry-level degree, much comment has been made about the appropriateness of a research component in the training of audiologists as well as a discussion of clinic-based research. EBP factors into this latter discussion as implementation of EBP has the potential to spur clinic-based research and ultimately, increased contributions to the pool of evidence available.

Barriers to EBP. EBP is not without its critics. While many agree with the theoretical concept of finding and applying current evidence to improve healthcare quality, barriers have 
been identified which cause them to question the practicality of adopting the practice. Zeitz and McCutcheon (2003) suggest that "EBP is not the immediate solution to achieving best practice" (p. 272) in the profession of nursing. Their rationale is based on their reflection of day-to-day nursing practices of gathering patient vital signs in postoperative care. They further discuss the parameters that seem to define nursing best practice such as tradition, educational texts, hospital policy, and interpersonal qualities of clinicians and patients.

A recent digest of evidence-based practice research (Melnyk, 2005) includes a study of more than 1000 registered nurses conducted by Pravikoff, Pierce, \& Tanner (2005). Results revealed that approximately one-third of the participants felt that they seldom or occasionally needed information and that half were not familiar with the term “evidence-based practice”. Melnyk makes several recommendations for improving the practice of using the best available evidence to support clinical practice as well as increasing awareness and familiarity with the practice during the education of future clinicians. She suggests that forcing students to participate in research has created a negative perception and that the evidence-based practice model should be introduced and applied consistently beginning earlier in the education of health care professionals. With earlier exposure to reading and consuming research findings, perhaps students are less likely to react negatively when called upon to participate in research requirements.

Several authors have investigated barriers to evidence-based practice that interfere with adoption of the practice. Fell and Burnham (2004) found that teaching physical therapy students to access evidence was a critical factor in students’ application of EBP principles. They determined that students must learn how to access and evaluate evidence in order to apply the concepts of EBP into clinical decision-making. Thompson, et al. (2005) found three primary 
barriers to evidence-based practice in nursing. They first identified gaps between knowledge and skills of locating and consuming research. Assorted concerns from limited computer skills and difficulty understanding statistical results to the lack of focused education in research methods are included in these gaps. Second, the need for consistent formats for making sense of empirical results interferes with adoption of EBP. And third, limited access to information in an environment of limited time is reported. An underlying theme of the three predominant barriers is the lack of time in the workplace to apply EBP principles. Another barrier included in their findings is limited physical location of Internet-connected computers in exam/treatment areas.

Mullen (2005) studied adoption of EBP principles among speech-language pathologists and audiologists. He found that $81 \%$ of speech-language pathologists and $70 \%$ of audiologists in his study group cited insufficient time as the primary barrier to the practice. Sackett, et al. (1996) address the criticisms of some who argue that evidence-based practice may be feasible in training programs in higher education but are not practical for the daily stress of busy clinical practice. Studies cited have demonstrated that EBP can be successfully adopted in clinical practice when readings are devoted to "selective, efficient, patient driven searching and appraisal” (p. 72). Cartwright, Korsen, and Urbach (2002) reported a study designed to teach medical school faculty to implement EBP strategies so that they could more effectively help residents become efficient in the practice. Their study included training for faculty in computer basics, faculty workshops and projects that required implementation of EBP principles, and improvement in technology infrastructure. Participants reported that following the training, they had improved several basic computer skills and had learned skills in accessing Web-based evidence and medical information. These authors indicate that although faculty was skilled at reading medical literature and using the information, they still needed training in computer skills and Internet search 
strategies. These skills are part of the emerging science of medical informatics, or healthcare informatics.

Healthcare informatics and knowledge management. Closely related to evidence-based practice is the field of healthcare informatics. Defined as "the scientific field that deals with biomedical information, data, and knowledge, and their storage, retrieval, and optimal use for problem-solving and decision-making” (Brock \& Smith, 2007, p. 1), healthcare informatics is an emerging profession with roots in medicine, computer science, and library science. Due to the increasing reliance upon information technology in medical settings, physicians, nurses, and other healthcare providers must have the skills to access and use electronic information. Paper patient files are becoming obsolete as electronic medical records (EMRs) store patient demographics, diagnoses, and treatments including electronic prescriptions. This data is amassed in databases and healthcare systems that have the potential to allow healthcare providers to track patient progress and to search for treatment strategies that have been successful for other patients.

One can see the same goal in healthcare informatics as in evidence-based practice - the desire to provide quality healthcare. Cartwright, Korsen, and Urbach (2002) report that "medical informatics is intricately linked to the evolving clinical emphasis on practicing evidence-based medicine (EBM), which relies heavily on access to the most up-to-date information in a quick and efficient manner, allowing application of that information during the patient encounter” (p. 386). Yet while EBP focuses on the search, application, and evaluation of empirical evidence, healthcare informatics addresses the larger picture of all healthcare data and its use.

A study by Westbrook, Coiera, and Gosling (2005) demonstrated that physicians and nurses who used an online information retrieval system to locate answers to clinical questions 
improved their accuracy in answering the questions than without access to information by $21 \%$. Although they looked at the time spent online, it did not appear to be a variable in the study and was only reported as not exceeding the time permitted participants during the initial non-access phase. The online information retrieval system used in this study was a set of computers with Internet access to six previously selected medical bases, a healthcare informatics system. The authors' conclusions indicate that their online retrieval system is appropriate for inclusion in a limited database of tools available in a medical environment.

Management of intellectual assets is a concern of many including researchers, physicians, other health care providers, and business managers and executives, as well as institutions of higher education. Rosenberg (2001) defines knowledge management as “creation, archiving and sharing of valued information, expertise and insight within and across communities of people and organizations with similar interests and needs” (p. 66). Peel, as cited in Georgiou (2002) defines knowledge management as "the discipline that integrates biomedical sciences, computer sciences and health care policy, management and organization” (p. 128). Knowledge management, therefore, can be viewed as a larger framework in which evidence-based practice resides.

Knowledge management may be visualized as a pyramid, with its foundation comprised of data. Individual pieces of data are essentially meaningless in and of themselves. However, the combination of data produces information, the middle tier of the pyramid. Information attempts to make sense of the data fragments and is useful for application in problem-solving, strategies, and procedures. Yet the information remains static unless it is applied in some manner. That application forms the upper tier of the pyramid - knowledge. Knowledge is the tool with which 
clinicians evaluate, diagnose, and treat their clients. It, combined with skill, is the underlying goal of graduate education in audiology, or any other health care field.

Figure 2. Knowledge management pyramid.

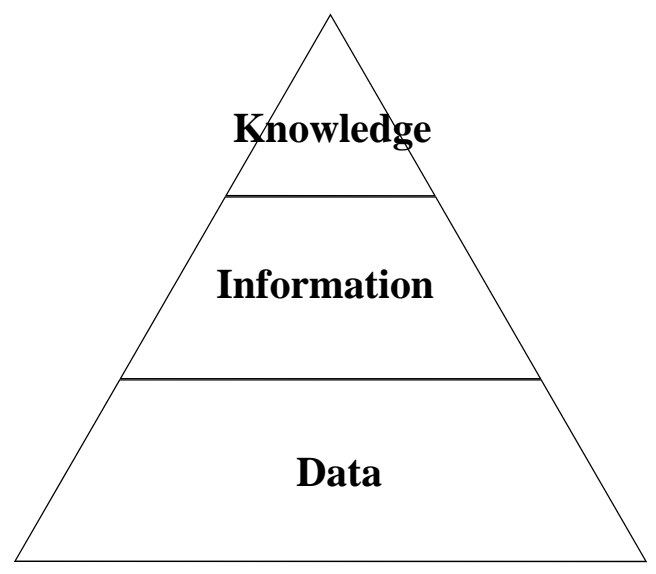

It should be stated that the presence of data does not guarantee ultimate creation of information and knowledge. Further, knowledge may arise from data, however its application may not be realized. Georgiou (202) argues that medical knowledge comes only from “open scientific discourse” (p. 129) or in expertise. He raises an important question about knowledge in healthcare professions - will future technological developments continue to support and stimulate knowledge in medicine?

Strategies for Clinical Learning

Reflective practice. Reflective practice is frequently used in the training of clinicians, including pre-service teachers. Examination of methods either observed or practiced in retrospect allows developing clinicians to self-evaluate and expand or re-visit their methods. Reflective practice as a goal of teacher education was highlighted during the 1980's in the United States and has enjoyed new attention in recent years. According to Kremenitzer (2005), reflective practice in education can be traced to Dewey in the 1930’s. Schön, as cited in Russell, 2005, 
differentiated between reflection-on-practice (essentially thinking over recent past events) and reflection-in-practice (a sudden new perspective). Russell studied his own pre-service teachers' development of reflection-in-practice as he guided them through self-assessment of their observational and field experiences in the schools. He concluded that reflective practice can indeed be taught, with attention to careful formulation of strategies on the part of the educator.

Kremenitzer (2005) presents a study of her instructional method of requiring early childhood teacher preparation students to maintain a journal of their own emotional intelligence as an outcome of reflection throughout their experiences in the classroom. She concluded that when early childhood teachers are aware of their own emotional status, they are better able to help young children begin to examine their own emotions. The reflective journaling that her students maintained were guided with codes as well as allowing commentary, to facilitate ease of maintenance, although this feature was not the focus of her paper.

Riley-Doucet and Wilson (1997) studied reflective practice to facilitate critical and analytical thinking in nursing students. Their nursing students were required to maintain a journal including reflections of daily clinical practice. The authors designed three areas of content to be addressed by students: critical appraisal of their experiences, reflections to be shared in peer group discussions, and self-evaluation. Students had the freedom to explore any aspect of clinical practice and were not required to share their journals with the instructors, although they could choose to do so. The authors conclude that students reported "an ability to recognize their strengths and their own growth more readily when they follow a self-directed approach to evaluating their own learning” (p. 967).

Reflective journaling is not confined to preparation of teachers and nurses. Journal writing with a focus on self-reflection appears in many educational contexts, including 
geography, sociology, and athletic training education. Leaver-Dunn, Harrelson, Martin, and Wyatt, as cited in Walker (2006), promote reflective practice, indicating that expert practitioners are distinguished among their peers by their ability to reflect upon their experiences in addition to their knowledge in order to make appropriate decisions. Walker describes options for design of journal-writing assignments for athletic training students focusing on reflective practice. By clearly defining instructor expectations, such as purpose of the journal, frequency of entries, appropriate topics, and feedback, students are free to focus on writing. She makes several recommendations for further research in reflective journaling with attention to how learning is affected, how students learn to reflect on their experiences, and others.

McIntyre and Tlusty (1995) recommended email as a preferred method for generating and sharing dialogue journals in teacher education. These journal entries were shared with instructors and peers electronically. Students then received electronic comments in response. They addressed potential pitfalls including rapid changes in technology, which in retrospect was insightful. Current course management systems provide a means of creating and sharing journal entries and reduce the load on instructor email in-boxes, the authors concluded.

In a study conducted by Chabon and Lee-Wilkerson (2006), students in a communication sciences and disorders (CSD) course were required to complete journal entries based on course content and clinical experiences. Based on the journal entries, the authors identified strengths and weaknesses of the journal writing assignments in relation to course learning outcomes. Critical thinking skills and identification of target characteristics and desirable skills were evident in the journal entries. The authors conclude that the journals enabled students to reflect on specific questions and “directed them to consider what they had heard, read, or experienced 
and relate this to their clinical practice.” They further conclude that the use of journal writing to assess student learning offers "significant potential.”

Clinic journals. The use of journals to document clinical experiences and reflection has been used in speech-language pathology as well as nursing and psychology. While traditional journals are generally considered private expressions of the writer's thoughts and feelings, clinic journals tend to be assigned and read by a clinical supervisor. The content is usually guided by designated topics or questions to be addressed by the student clinician as a reflection of clinical practicum and may be graded or evaluated in some manner. Boud (2001) describes journals as a “device for working with events and experiences in order to extract meaning from them.” A study by Ruthman, Jackson, Clusky, Flannigan, Folse and Bunten (2004) described a clinic journaling assignment in a nursing program. Nursing students typed daily journal reflections which were reviewed by faculty during several clinical rotations. The authors describe the clinic journals as follows:

The purpose of clinical journaling is to serve as a mode of communication for students and faculty that records student accomplishments and challenges throughout all clinical courses. It establishes the interactive learning process, captures course objectives, and by stimulating reflective thinking, offers opportunities to demonstrate analytic and written communication skills (p. 121).

Their study was a collaborative effort between nursing and English faculty and addressed general curriculum goals for development of writing skills, as well as nursing-specific skills. They demonstrated that students learned self-reflection, cognitive effort, self-evaluation, and goalsetting. Additionally, advanced nursing program students found the assignments redundant and time-consuming. Sophomore students appeared to report more benefit than seniors. Nursing 
faculty indicated that they found the clinic journal assignment as beneficial. They reported that they could identify student progress, engagement in learning, critical thinking skills, and a means for students to communicate their thoughts, concerns and developing skills.

Cisero (2006) reported the findings of a study comparing college student examination grades between students enrolled in three semesters prior to the implementation of assigned journal reflections on assigned readings and those enrolled in the same course over two semesters with the journal activity. She found small differences in numeric point values between groups, however significantly fewer students earned "C" \& "D" grades and slightly more "A" \& "B" grades in the intervention group compared with the control group.

Weblogs. Weblogs are no longer a new phenomenon. They have been a regular fixture on the World Wide Web since the late 1990’s. According to Descy (2004), the term “weblog” was coined in December, 1997 by John Barger, and was later shortened to "blog”. Weblogs began as a way to publish individual commentary and opinions on current issues on the Internet, primarily by linking or "logging" other web pages the author found interesting. During the 2002 Presidential Elections, blogging became popular as Democratic primary candidate, Howard Dean maintained communication with his supporters via his blog. His blog enabled his supporters to remain current on campaign issues as well as raise significant funds. Du and Wagner (2006) presented the findings of their study that evaluated successful characteristics of Weblogs. They categorized characteristics of the top 100 blogs, based on number of readers and concluded that the single most important characteristic of successful Weblogs is content, in spite of available features that may be desirable to bloggers (weblog authors).

Blogs are essentially websites that are pre-formatted by the weblog publisher or software. Therefore, users do not need to know html editing nor web page design and creation. The most 
recent addition to a blog appears at the top of the Web page and previous posts appear in reverse chronological order. Most Weblog services offer archiving of posts, to aid in organization. Posts can be archived weekly or monthly, at the user's preference.

Blogs have become so popular that many public entities, including cable news channels, sports outlets, and celebrities have regularly updated blogs on their websites. Trammel, Williams, Postelnicu, and Landreville (2006) studied the Website and blog content of ten candidates for the Democratic nomination for the Presidency of the United States during the 2004 primary election cycle. They concluded that political campaigns "attempted to engage voters...through fostering a spirit of interactivity through the content on campaign sites and blogs” (p. 42).

Perhaps the most extensive study of Weblogs in terms of demographics, and most cited, is that presented by Kaye (2005) in which she attempted to determine who is reading Weblogs and why. She surveyed nearly 4,000 weblog readers over a one-month period and identified "six primary motivations for accessing Weblogs” (p. 73) - from a quest for information to an outlet of expression. Her profile of the 2005 blog-reader is interesting and perhaps somewhat predictable. The overwhelming majority of blog-readers was male Caucasian, with a college degree and median income who had spent over seven years accessing the Internet. He was highly interested in politics. She indicates that as Weblogs increase in popularity and readers become more diverse, the motivation for reading blogs could be expected to change.

Bloggers can create a single blog and invite multiple authors to participate. They also can allow, or disallow, public and/or private comment on their blogs. Blogging has been adopted in higher education in both of these manners. A faculty member can create a course blog and include all students in the course as co-authors or users. This type of blog has been used to post 
class announcements, assignments, and further discussion of in-class topics. It has also been used to facilitate online learning environments. Course instructors post focused questions or relevant topics and assign students the responsibility of posting thoughtful responses and discussions.

Glogoff (2005) calls blogging in education a “knowledge-centered instructional tool” (ף 3). He envisions course instructors using blogs to facilitate research, online interaction with professionals, and the development of the knowledge domain of an area of study. Following the implementation of blogging in an information resource and library science course he teaches, he concluded that "by the end of the course, students had analyzed the deeper structures necessary to make sound decision when evaluating information systems for use or purchase.” He also reported several learning models that support the use of Weblogs in education, including learnercentered, social learning, and community-centered instruction. He identified an area of concern in which students who did not seem to be interested in the assigned topic refused to participate in the blog, in spite of it being a course requirement. On the other hand, students who demonstrated interest in the topic, regularly participated. One may wonder if other factors were involved in some students not participating, such as limited technology skills or hesitance to expose thoughts and feelings in a community environment.

Studies have demonstrated that such application of blogs is most beneficial when (a) students have been instructed in how to access and post to the blogs (Bryant, 2006), (b) clear expectations are given, (c) blog posts are assessed in some manner, and (d) instructors are active participants in the blog (Windham, 2007). Windham further suggests that if students believe that the blog assignments are 'busy work' with little or no academic value, they are less likely to participate, or may post the obligatory assignments without careful attention to the task. 
Martindale and Wiley (2005) found that students who actively participated in carefully planned and managed blogging assignments became engaged in the content, as well as the process.

Several sites, such as Blogger and LiveJournal, offer free blog accounts to users. The creation of a user name and password are required, as well as a valid email address, to set up an account. Creating a blog account at one of these services takes no more than 15 minutes, and users can post and view their blogs within minutes. For individuals or institutions with their own servers, commercially available software can be downloaded to the server and set up to host the users’ blogs.

Downes (2004) discusses five applications of Weblogs in the classroom that he has observed: using blogs to replace a classroom Website; managing a selection of Internet links related to class content; facilitating class discussion; providing reading summaries and seminars; and creating student-generated posts. He states that because Weblogs are so easy to use, they are attractive additions to the classroom. In addition to previously discussed learning models, Hernández-Ramos views blogs in education as facilitative to constructivist learning. By assigning an open-ended question to his teacher education students, he believes he helps them to create their own knowledge. This view can be supported by the practices of evidence-based practice as well as knowledge management.

A study by Bouldin, Holmes, and Fortenberry (2006) investigated the use of Weblogs in a pharmacy course. Instead of using a web-based blog service, they used a commercially available system installed on their departmental server. Students were required to post two entries to their blogs weekly. At the end of the semester, student feedback was elicited and was analyzed as well as blog grades. While the majority of students indicated that they felt that the blog assignments helped them learn course content better, nearly $20 \%$ indicated that they felt the 
blog assignments were not beneficial to their learning. The authors discuss the role of critical analysis in education and wonder if students rarely reflect on course content unless required. Although the weblog format was not the focus of this study and did not appear to confound the results, one must consider the difference between Web-based blog services that are essentially in the public domain and those housed in a secure server. Does the sense of security that comes with believing that a limited number of readers have access to one's blog have an impact on the degree of participation one makes? Or conversely, does the thought that an expert in the field may stumble across one’s blog impact the quality of contribution to blog posts? When assigning blogging using a Web-based blog service, faculty is advised to warn students to guard their privacy and maintain their individual blogs with a level of confidentiality. Implications of careless regard to confidentiality may make students vulnerable to all sorts of negative consequences of having a presence on the World Wide Web. Unwanted attention and prospective employers have been known to surf the Web for information on individuals.

Blogging is common practice in international news journalism and therefore it is not surprising that it has been adopted in journalism education. Beeson (2005) reports on blogging assignments in journalism courses he has encountered. He comments that "the huge pressure brought on by the blogs made many students take extra care in editing their articles prior to posting" and "added a sense of camaraderie to the class" (p. 27). This seems to reinforce the desired effect of creating a social learning environment as well as emphasizing self-reflection. Beeson further reports the comments of a journalism professor who found gratification in the use of blogs in his course because it "took the professor out from behind the podium. He is a participant instead of a fountain head” (p. 29). This comment is a reflection of true $21^{\text {st }}$ century learning in practice. 
Oravec (2002) echoes the emphasis on analytical and critical thinking that is reinforced by the use of Weblogs in the classroom. She observes that students pose thoughtful responses to peer comments and are able to define their own opinions about content as well as context. She further observes that by including links into posts, Weblogs serve as a way to manage online information, or as she phrases it, "bookmarking the world” (p. 616). Flatley (2005) comments that students in her courses used Weblogging as a means of collaboration. She considers blogging as supporting learner-centered education.

Stiler and Philleo (2003) studied reflective practice in pre-service teachers using Weblogs instead of traditional paper journals and other Internet technology options such as email and discussion boards. Students were asked to anonymously evaluate the use of the Weblogs at the end of the semester regarding their satisfaction, ease of use, changes they would recommend and further applications of Weblogs in education. Overwhelmingly, students responded that the weblog technology was easy to learn and did not require extensive time to learn. The majority reported that they considered themselves intermediate regarding computer skills and that they recommended further use of Weblogs in the courses. Interestingly, when the authors compared the quality of blog posts with the previous semesters' paper journals, they found the blog posts to be more analytic and evaluative, longer, and more reflective. They indicate that the focus of their study was not to evaluate why differences were observed, but offered the possibility of the ease of use the weblog service offered in facilitating participation. This presents a question to be answered by future research.

Weblogs in clinical learning. Graduate students in a Doctor of Audiology program in a mid-Atlantic university complete two semesters of graduate coursework prior to beginning clinical practicum experiences. Clinical practicum begins in-house, with students spending three 
semesters in the in-house academic hearing clinic where students are typically scheduled for one to one and a half days per week. As they progress through the program, they are assigned more time in the academic clinic, and eventually to several outside placements in the local area. The knowledge and skills developed in clinical practicum are presumed to increase with time and complexity of cases. Although complexity of cases cannot be completely predicted, types of cases and hence the competencies students may acquire can be anticipated based on the type of clinical placement. Basic hearing evaluations, hearing aid evaluations and orientations, and auditory processing evaluations are common in the academic clinic. Practicum sites where services are provided in conjunction with otolaryngologists are expected to provide students with more advanced experiences such as electrophysiological testing, cochlear implants, and interoperative monitoring. Private practice sites tend to provide experiences with higher volume hearing aid clients, consulting, and business management. A variety of these types of sites are available to these AuD students, however students rotate through the sites and therefore may not have the opportunity for experiences with unique or uncommon cases.

\section{Summary}

Nationally, the profession of audiology has been devoting attention to adopting and promoting evidence-based practice in recent years. Faculty in both speech-language pathology and audiology has been introducing graduate students to the principles and strategies needed to incorporate evidence-based practice, however clinical application has been slow, especially in outside practicum sites where the pace is faster and more stressful. The Council for Academic Accreditation, which accredits graduate programs in audiology as well as speech-language pathology, recently updated program accreditation requirements that include knowledge and 
skills in EBP. Therefore, graduate students will need to develop the skills associated with implementing EBP into clinical practice, in addition to knowledge.

Clinical supervision, or clinical teaching, styles vary among supervisors. The majority of supervisors providing supervision for graduate students have several years of experience. AuD students must learn to merge theory and knowledge gained in the classroom with often fastpaced clinical decision making. One limitation of clinical practicum in this type of setting can be a supervisor's reliance on familiar techniques or procedures that are not supported by evidence. These habitual patterns may then be passed down through the profession, although they have little or no validity. This is not unique to audiology, and essentially forms the foundation for why evidence-based practice developed as a clinical strategy in every healthcare field.

The process of searching for evidence that supports clinical practices and sharing that evidence with student peers could be expected to do the following: immerse Doctor of Audiology students into the research literature, facilitate analysis of research validity and quality, train future professionals to rely on evidence, and ultimately, provide quality services to clients. Doctor of Audiology students must be taught what evidence-based practice is, as well as how to find and use clinical evidence. The task of teaching EBP skills is the responsibility of clinical supervisors and clinic coordinators.

With the transition from the master's degree in audiology to the AuD degree, the author initiated the practice of electronic journals, or Weblogs, for students to reflect upon and share clinical learning experiences with their peers. Students had to be taught what a Weblog is and how to create and maintain one. The author conducted a computer lab training session each year to introduce $\mathrm{AuD}$ students to blogging and to assist them in creating their own blog to be used for clinical journaling. Students were advised that they could choose whichever blogging service 
they preferred and were provided with a hyperlinked list of free Web-based blog services. The author had created a blog prior to the first training session on Blogger (http://www.blogger.com) and used it to demonstrate the process for students. Initially, all students opted to use Blogger as their blog host however most recently students have begun to explore other free blog services and have opted to use them.

While creating their blogs, students were encouraged to pay close attention to their blog settings in regards to guarding their privacy as well as concern for client privacy. Options to limit their blog presence in the host directory and to limit comments in some way are stressed. Strict guidelines are given to students regarding client privacy issues. Posting any identifying client information, site information, and supervisor information is prohibited. Infractions result in the student being required to delete or modify the post immediately and can lead to more serious consequences if not addressed.

By studying Doctor of Audiology students’ clinic Weblogs, I investigated what they learn about evidence-based practice, what their reactions were to reading and writing clinic Weblogs, and what their reactions were to evidence-based practice. The value of writing clinic journals has been discussed in research literature above. The value of sharing evidence supporting clinical practice via an electronic clinic journal among peers was explored in my study. 


\section{CHAPTER 3}

Method

Weblogs and Evidence-Based Practice

Research questions. Three questions were specified in this study.

1. What do AuD students learn about evidence-based practice from writing and reading clinic Weblogs?

2. What are AuD students' reactions to writing and reading clinic Weblogs?

3. What are AuD students' reactions to evidence-based practice?

Participants. Participants in this study were graduate students in the Doctor of Audiology program at West Virginia University who had posted and discussed evidence related to their clinical experiences between August 15, 2005 and April 27, 2007. Of the 29 students enrolled and 11 graduates at the time of this study, 17 qualified for participation. The AuD program at WVU is a four-year full-time program. Eight students enrolled in their first year of study (Class of 2012), nine students enrolled in their first year of study (Class of 2011), and six students enrolled in their third year of study (Class of 2010) were not considered participants since they had not participated in the blog assignment as described in this study. Potential study participants therefore were among the six current fourth year students (Class of 2009) and the eleven graduates of the program, the first of whom graduated December 2006. It should be noted here that participants from the Class of 2006/2007 were not required to incorporate evidence-based practice into their blogs, however their blogs inherently included appropriate citations and discussions of evidence from the audiology literature. They were also able to respond to the interview questions based on their participation in the blog assignment. 
The 17 potential study participants were contacted via email to inform them of the purpose of the study and describe the interview process. Nine of the 17 potential study participants returned signed consent forms and were interviewed for this study. See Table 1 for a visual representation of participants.

Table 1.

Study Participants in Relation to All Current AuD Students

\begin{tabular}{|c|c|c|c|c|c|c|}
\hline $\begin{array}{c}\text { Number of } \\
\text { AuD } \\
\text { students, } \\
\text { by class }\end{array}$ & Class of & Class of & Class of & Class of & Class of & Class of \\
& $2012(8)$ & $2011(9)$ & $2010(6)$ & $2009(6)$ & $2008(5)$ & $\begin{array}{c}2006 / 2007 \\
(6)\end{array}$ \\
\hline
\end{tabular}

Note: Study participants are identified in shaded cells.

In addition to interview data, blog content from August 15, 2005 through April 30, 2007 was coded and analyzed for emerging categories and themes. The blog assignment was first introduced to the enrolled students mid-August 2005. During our regular pre-semester clinic meeting, I helped students set up their free blog accounts and practice writing blog posts. They shared their blog Uniform Resource Locators (URLs, or Web links) with their peers and me, and practiced reading and commenting on peer blogs.

As the hearing clinic coordinator, I was responsible for assigning clinic grades for $\mathrm{AuD}$ students enrolled in regular clinical practicum during their second and third years of the program. Clinic grading was designated "Satisfactory" or "Unsatisfactory" and was based solely on clinic performance as reported by clinic supervisors at the end of each semester. I also served as one of three in-house clinic supervisors for AuD students during the second year of their program and provided approximately $75 \%$ of the weekly supervision. It should be noted here that during the 
time period from which blog data was collected (August 15, 2005 through April 30, 2007), no grades had ever been assigned to the blog activities and blog activities were not a consideration in the assignment of semester clinic grades. During that time period, several students posted blogs irregularly or rarely. No consequences resulted from failure to blog. Since April, 30, 2007, a rubric was developed to provide student feedback on their blogs, for reasons that will be discussed in the study conclusions. No blogs posted after April 30, 2007 were included in the study.

Description of the intervention. At the beginning of every semester, I held a clinic meeting with all AuD students enrolled in clinical practicum for the semester. During this meeting, I gave the instructions and guidelines for writing and reading clinic Weblogs. The information is also included in the clinic packet that I hand out to each student. Following is a list of the Weblog assignment characteristics:

- Write a new post to their Weblog each week during clinic assignments

- Select a specific case or procedure experienced in clinic that week

- Search for evidence that addresses the specific case or procedure

- Summarize the evidence in the blog and suggest appropriate application of the evidence

- Include the reference for the evidence.

- $\quad$ Read and comment on peer blogs weekly

Information about the blog assignment included in the clinic packet address issues of confidentiality and privacy, a description of what constitutes appropriate evidence, and what types of sources (specifically, commercial and consumer-targeted Websites) are not considered clinical evidence. No formal training in evidence-based practice was provided during this regular meeting. (This is addressed later in chapter 5.) 
Clinical practicum occurred over a thirteen-week period during the fall and spring semesters and over a six-week period in the summer. Doctor of Audiology students at West Virginia University began their clinical practicum during the summer session following their first year of courses. Their first placements were in the in-house academic clinic in Allen Hall and were later in outside clinic sites in the Morgantown-Clarksburg area with certified audiologists who agreed to provide supervision in their facilities. These clinical assignments spanned 6 semesters, including summer semesters.

Study timeline. The first clinic assignments for the Fall 2005 semester began September 2, 2005. Each in-coming class of AuD students received the same orientation to blogging described above just prior to their first clinical assignments. The final date of clinic assignments for the Spring 2007 semester was April 27. Therefore, the study time frame for analysis of blog entries was designated August 15, 2005 through April 30, 2007, which allowed for any students who may have had an April 27, 2007 clinic experience time to post to their blog. Content from early practice blog posts completed prior to the first clinical practicum assignments did not contain clinically pertinent content and were therefore disregarded, for the purposes of this study.

Data sources. AuD student-generated blog posts (or entries) spanning the time period from August 15, 2005 through April 30, 2007 were analyzed for emergent categories and themes. All blogs posted during the study period (396 posts) were copied and pasted into Microsoft Word and saved into Rich Text Format (.rtf).

In addition to blog content, participants were interviewed. Questions were created to probe for responses regarding perceived definition of evidence-based practice, perceived purpose of evidence-based practice, perceived value of writing and reading clinic Weblogs, barriers or limitation to writing and reading clinic Weblogs, and specific clinic practices learned or 
supported by evidence uncovered from writing and reading clinic Weblogs. Other questions posed sought reactions to writing and reading clinic Weblogs and evidence-based practice. See Appendix B for a list of interview questions. Participants were given pseudonyms in alphabetical order based on order of interview completed. In other words, the first interview participant was given a pseudonym beginning with the letter “A”, the second interview participant was given a pseudonym beginning with the letter "B", and so on. Because all students who qualified for participation were females, feminine pseudonyms were assigned. All interviews were conducted by speakerphone in a private setting. Interviews were recorded with either a Radio Shack model CTR-122 audio cassette recorder with standard size audio cassettes or a Radio Shack model Micro-44 voice-activated micro-cassette recorder with micro-cassettes. Interviews were transcribed word-for-word using Microsoft Word and were saved in .rtf format and saved on data compact discs (CD). Printed and saved documents were stored in a locked cabinet in my office when not being analyzed.

The emergent categories and themes were also compared with national certification requirements found in the American Speech-Language-Hearing Association's Knowledge and Skills Acquisition (KASA) that is required of programs for documentation of student clinical competencies as they are met. (See Appendix A).

Finally, an anonymous Web-based survey was administered to participants via West Virginia University Web Service’s survey tool, SimpleForms. The survey used a five-point Likert-type rating for responses to questions (see Appendix C) about participant reactions to writing and reading clinic Weblogs and evidence-based practice. One open-ended question offered participants the opportunity to comment on any aspect not addressed in the survey questions. The link to the survey was emailed to all participants concurrently, six weeks after the 
last interview was completed. The survey was available for a three week period and participants were informed of the opening and closing dates of the survey. No identifying or computer information was collected in the survey. The Likert-type scale points were consistent for all questions, with the exception of the open-ended question. Scale values are as follows: $1=$ strongly disagree; 2 = agree; 3 = neutral; 4 = agree; and 5 = strongly agree. One survey question was posed as a negative statement - "I learned very little about evidence-based practice in my clinical practicum experiences.

Data analysis. Blog content was analyzed using qualitative analysis methods of document analysis. Data was analyzed for emergent categories and themes. This data was triangulated with interview analysis as well as comparison with competencies required for national certification as specified on ASHA's Knowledge and Skills Acquisition form. Survey data was analyzed quantitatively and reported as frequency responses.

TAMS $\subset$ and TAMS Analyzer@ software were used to code and analyze the blog content for categories and themes. TAMS@ and TAMS Analyzer@ Weinstein for qualitative research on MAC OS X, Unix, and Linux platforms. Only .rtf files can be coded and analyzed in TAMS $\subset$ and TAMS Analyzer@ $₫$. This data helped answer what AuD students learn about evidence-based practice from writing and reading blogs.

Results of the qualitative data analysis revealed strengths and weaknesses of the Weblog assignment in facilitating evidence-based practice among Doctor of Audiology graduate students. I anticipated conclusions and implications to include recommendations regarding modifications and future use of Weblogs for the assignment. Additional recommendations for teaching evidence-based practice to AuD students were also determined. 


\section{CHAPTER 4}

Results

\section{Research Question 1}

My first research question asked: What AuD students learn about evidence-based practice from writing and reading clinic weblogs? Data to answer this question was found in analysis of all blog posts and interview transcriptions.

Blog analysis. All blog entries posted during the study time frame (396 posts) were coded and analyzed for emergent categories or themes related to evidence-based practice (EBP). Frequency counts of codes were used to list categories in order of occurrence. Eight categories representative of answers to this question emerged from the data and of these, three predominated the remaining categories. Table 2 below illustrates emergent theme categories coded from all blog data and the corresponding frequency counts. All eight categories and corresponding frequency counts can be found in Appendix D.

Table 2.

RQ1: All Blog Data EBP Predominant Categories and Frequency Counts.

\begin{tabular}{|l|l|}
\hline \multicolumn{1}{|c|}{ Categories } & \multicolumn{1}{c|}{ Frequency Counts } \\
\hline Discussion of evidence & 80 \\
\hline Reference citation of evidence cited & 73 \\
\hline Web links to evidence referenced provided & 64 (of the 73 citations above) \\
\hline
\end{tabular}

Discussion of evidence comprised the largest category. Eighty of the 396 blog posts contained some discussion of evidence uncovered as it related to the clinical experience they reported in their blog. Among these 80 posts, blog writers provided further discussion of the evidence the blog-writer had uncovered in relation to the case they presented in their blog post. Quotes used to represent this category were taken directly from the blog posts and appear to 
summarize the discussion that was read in the post. See Table 3 for select quotes representative of the "Discussion of evidence” category.

The next category observed by frequency (73 of 396) was references for evidence cited in the blog posts. This code was limited to references of research articles of various designs, which would be considered consistent with appropriate evidence. Web links were provided to 64 of these 73 references. Other blog posts included links to Websites of commercial or opinion-based information that would not be considered valid evidence. Information found on these sites may in fact be based on evidence, however they are not a primary source of evidence and therefore were not coded to "Web links to evidence referenced provided" above. More information about these Internet article and Website categories can be found in Appendix D. Table 3 below displays select quotes from blogs that illustrate the code categories. 
Table 3.

RQ1. Select Quotes From Blog Content EBP Predominant Categories.

\begin{tabular}{|c|c|}
\hline Categories & Quotes from Weblogs \\
\hline \multirow[t]{4}{*}{ Discussion of evidence } & $\begin{array}{l}\text { "The article discusses the conditions and implications for } \\
\text { audiologic management," }\end{array}$ \\
\hline & “this definitely explains why 'ice cream' came out as 'i eam.”” \\
\hline & $\begin{array}{l}\text { "Although, it mainly focuses on the pediatric population it } \\
\text { provides a lot of useful information," }\end{array}$ \\
\hline & $\begin{array}{l}\text { "I decided to discuss a little about the effects hearing } \\
\text { impairments have on cognition" }\end{array}$ \\
\hline \multirow{3}{*}{$\begin{array}{l}\text { Reference citation of } \\
\text { evidence cited }\end{array}$} & “According to Desmond (2004),” \\
\hline & $\begin{array}{l}\text { "Intertest Variability and the Air-Bone Gap" (1967) Journal of } \\
\text { Speech \& Hearing Disorders, 32, 82-86,” }\end{array}$ \\
\hline & “(Moffat, 1989).” \\
\hline \multirow[t]{4}{*}{$\begin{array}{l}\text { Web links to evidence } \\
\text { referenced provided }\end{array}$} & $\begin{array}{l}\text { “http://psychsoc.gerontologyjournals.org/cgi/content/ } \\
\text { full/59/3/S190!!” }\end{array}$ \\
\hline & "http://www.fcc.gov/cgb/consumerfacts/hac.html” \\
\hline & $\begin{array}{l}\text { "http://www.asha.org/NR/rdonlyres/8404EA5B-8710-4636- } \\
\text { B8C4-8A292E0761E0/0/v2TR_CAPD.pdf” }\end{array}$ \\
\hline & $\begin{array}{l}\text { "http://www.audiologyonline.com/articles/ } \\
\text { article_detail.asp?article_id=345.” }\end{array}$ \\
\hline
\end{tabular}

Although the discussion and citations, with or without links, were very appropriate and demonstrate ability to at least locate evidence, the low prevalence of codes for discussion of evidence (80 of 396, or approximately 20\%) indicates that the overwhelming majority of blog posts contained no discussion of evidence. An even lower prevalence (73 of 396, or 18\%) of citations to evidence further indicates the lack of evidence found in the majority of blog posts. This suggests that although some learning about evidence-based practice occurred as a result of reading and writing clinic Weblogs, it cannot be concluded that in general AuD students learned EBP from the assignment. This will be discussed further in the next chapter. 
All blog content was also coded for comparison with competencies required for national certification in audiology as specified on ASHA’s Knowledge and Skills Acquisition (KASA) form. The purpose of the KASA is to document academic and clinical skills as AuD students form these competencies. Analysis of blog content did not confirm the acquisition of these competencies, but did indicate skills competency areas where AuD students gained exposure and experience. A table containing generalized KASA skill categories and frequency counts can be found in Appendix D. A table displaying frequency counts of codes in the standard KASA format can also be found in Appendix D. Predominant KASA skills areas and corresponding frequency counts, in descending order of frequency, are displayed in Table 4 below. Table 4.

RQ1: Predominant KASA Skills Standards Categories and Corresponding Frequency Counts

\begin{tabular}{|l|l|}
\hline \multicolumn{1}{|c|}{ Predominant KASA Skills Categories } & Frequency Counts \\
\hline KASA Evaluation & 273 \\
\hline KASA Evaluation Results & 230 \\
\hline KASA Treatment - Hearing Aids & 220 \\
\hline
\end{tabular}

It is clear from this table that AuD students blogged most often about their clinical experiences with evaluation of clients, the results of evaluations and hearing aids as the most frequently reported treatment for hearing loss.

Interview analysis. Interview data was also analyzed to answer Research Question 1: "What do AuD students learn about evidence-based practice from writing and reading clinic Weblogs?” Eight interview questions probed for an answer to this larger research question. See Appendix B for a list of the interview questions. The reader is reminded that nine participants were interviewed. Responses are counted in the table below and are not associated with individual interviewees. Therefore, in some instances, more than nine responses were made to 
the question. Again, responses were coded and categories emerged. Individual interview questions, The predominant emergent categories, the corresponding frequency counts of responses, and select quotes to the eight interview questions appear in Tables 5 though 12. Table 5.

RQ1A: Defining “Evidence-Based Practice” Categories, Frequency Counts, \& Select Quotes

\begin{tabular}{|c|c|c|}
\hline Category & $\begin{array}{l}\text { Frequency } \\
\text { Counts }\end{array}$ & Select Quotes \\
\hline \multirow[t]{3}{*}{$\begin{array}{l}\text { Defined by sources of } \\
\text { evidence }\end{array}$} & \multirow[t]{3}{*}{10 responses } & $\begin{array}{l}\text { "empirical evidence that has been proven } \\
\text { statistically significant” }\end{array}$ \\
\hline & & “published research” \\
\hline & & “studies done” \\
\hline \multirow[t]{3}{*}{$\begin{array}{l}\text { Validation of clinical } \\
\text { practices }\end{array}$} & \multirow[t]{3}{*}{6 responses } & $\begin{array}{l}\text { "support the practices that you do in your clinic } \\
\text { with your patients." }\end{array}$ \\
\hline & & “...back up what you're doing clinically” \\
\hline & & $\begin{array}{l}\text { “...found to be the most effective ways of doing } \\
\text { things" }\end{array}$ \\
\hline
\end{tabular}

The majority of responses to this question were definitions based on sources where evidence could be found. Others more closely approximated a correct definition by indicating that evidence-based practice is a method of validating clinical practices. This is actually the reverse of the true definition of evidence-based practice: "the integration of best research evidence with our clinical expertise and our patient's unique patient's values and circumstances” (Sackett, Straus, Richardson, Glaziou \& Haynes, 2000, p.1). 
Table 6.

RQ1B. Purpose of EBP Categories, Frequency Counts, \& Select Quotes

\begin{tabular}{|c|c|c|}
\hline \multicolumn{3}{|c|}{ 1B. How would you describe the purpose of EBP? } \\
\hline Category & $\begin{array}{l}\text { Frequency } \\
\text { Counts }\end{array}$ & Select Quotes \\
\hline \multirow[t]{3}{*}{ Application of evidence } & \multirow[t]{3}{*}{10 responses } & $\begin{array}{l}\text { "You have to know why you're doing what you're } \\
\text { doing." }\end{array}$ \\
\hline & & "bringing it in to your clinical practices" \\
\hline & & "to evaluate everything you do critically." \\
\hline \multirow[t]{3}{*}{$\begin{array}{l}\text { Benefits to patients from } \\
\text { using evidence }\end{array}$} & \multirow[t]{3}{*}{5 responses } & $\begin{array}{l}\text { "not putting your patients through something that isn't } \\
\text { valid for what they need or what needs to be done." }\end{array}$ \\
\hline & & “protect our patients” \\
\hline & & "made us think about our patients more” \\
\hline
\end{tabular}

Interviewees described the purpose of EBP as applying the evidence in clinical practices and ultimately benefiting patients by using the evidence. The response "to evaluate everything you do critically" is the statement perhaps most consistent with the purpose of the principles of evidence-based practice. 
Table 7.

RQ1C: Benefits from Weblogs Categories, Frequency Counts, \& Select Quotes.

1C. Do you see any benefits from writing and reading Weblogs about clinic experiences? If so, describe them.

\begin{tabular}{|c|c|c|}
\hline Category & $\begin{array}{l}\text { Frequency } \\
\text { Counts }\end{array}$ & Select Quotes \\
\hline \multirow{5}{*}{$\begin{array}{l}\text { Learned from reading } \\
\text { others }\end{array}$} & \multirow[t]{5}{*}{9 responses } & “you can learn from other people’s experiences.” \\
\hline & & $\begin{array}{l}\text { "when you read their blog, you kind of have a feel } \\
\text { for what they were really doing, 'cause you know } \\
\text { them so well." }\end{array}$ \\
\hline & & $\begin{array}{l}\text { "other people to look at your, what you did in a } \\
\text { situation to see how they would do it differently." }\end{array}$ \\
\hline & & $\begin{array}{l}\text { "I learned a lot more by reading - I don’t even } \\
\text { know how many people were participating in it - } \\
\text { but just reading what everybody else was going } \\
\text { through.” }\end{array}$ \\
\hline & & $\begin{array}{l}\text { "I read somebody's blog and the evidence they } \\
\text { had on there was on the Praxis exam." }\end{array}$ \\
\hline \multirow{3}{*}{$\begin{array}{l}\text { Learned from sharing } \\
\text { different experiences }\end{array}$} & \multirow[t]{3}{*}{6 responses } & "we each have different experiences in clinic" \\
\hline & & $\begin{array}{l}\text { "people fitting a certain hearing aid and people } \\
\text { that weren't. um, a lot of people had kids, other } \\
\text { people didn't.” }\end{array}$ \\
\hline & & "being able to read what they experienced" \\
\hline
\end{tabular}

Responses to the question "Do you see any benefits from writing and reading Weblogs about clinic experiences?” indicate that AuD students learned from their peers’ clinical experiences. Responses suggested that they compared their clinical experiences with those of their peers and learned from reading clinical experiences shared by their peers who had different clinical experiences. It is interesting to note that one respondent was able to identify from a peer’s evidence and later apply that evidence to the Praxis examination. 
Table 8 .

RQ1D: Benefits from EBP in Weblogs Categories, Frequency Counts, \& Select Quotes.

1D. Do you see any benefits from including EBP into the Weblogs? Explain this for me.

\begin{tabular}{|c|c|c|}
\hline Category & $\begin{array}{l}\text { Frequency } \\
\text { Counts }\end{array}$ & Select Quotes \\
\hline \multirow[t]{4}{*}{$\begin{array}{l}\text { Validation of clinical } \\
\text { practices }\end{array}$} & \multirow[t]{4}{*}{7 responses } & $\begin{array}{l}\text { “it encouraged me to verify everything that I’ve } \\
\text { done.” }\end{array}$ \\
\hline & & $\begin{array}{l}\text { "there is way more benefit of providing the } \\
\text { evidence" }\end{array}$ \\
\hline & & "gives you data and reasoning behind it" \\
\hline & & $\begin{array}{l}\text { "because if you can’t back up what you're doing, } \\
\text { like I said, you shouldn’t be doing it.” }\end{array}$ \\
\hline \multirow[t]{3}{*}{ Continued Learning } & \multirow[t]{3}{*}{6 responses } & $\begin{array}{l}\text { "I think it’s good because you don’t really } \\
\text { understand it yet. Like I still am learning every } \\
\text { single day.” }\end{array}$ \\
\hline & & $\begin{array}{l}\text { "helps the student know what they need to look for } \\
\text { and evidence-based articles" }\end{array}$ \\
\hline & & "it makes you think" \\
\hline \multirow[t]{3}{*}{ Improved patient care } & \multirow[t]{3}{*}{5 responses } & $\begin{array}{l}\text { "made us look into finding more answers and } \\
\text { looking outside the box to find possible solutions } \\
\text { for what they needed" }\end{array}$ \\
\hline & & "made us think about our patients more" \\
\hline & & $\begin{array}{l}\text { "make sure that your patients are getting the best } \\
\text { care." }\end{array}$ \\
\hline
\end{tabular}

Participants indicated that they found benefits from including EBP into the Weblog assignment because they believed that it served to validate their clinical practices, they continued to learn, and that patient care improved as a result of learning evidence-based practice. 
Table 9.

RQ1E: Barriers to Writing Weblogs Categories, Frequency Counts, \& Select Quotes

\begin{tabular}{|c|c|c|}
\hline Category & $\begin{array}{l}\text { Frequency } \\
\text { Counts }\end{array}$ & Select Quotes \\
\hline \multirow[t]{3}{*}{$\begin{array}{l}\text { Selection of cases to } \\
\text { discuss }\end{array}$} & \multirow[t]{3}{*}{5 responses } & $\begin{array}{l}\text { "being able to pick out one case study uh, versus } \\
\text { your whole day, your whole week to be able to } \\
\text { talk about was sometimes difficult" }\end{array}$ \\
\hline & & $\begin{array}{l}\text { "it was just kind of hard finding good topics to } \\
\text { discuss a lot about, I guess. And find actual } \\
\text { evidence on it." }\end{array}$ \\
\hline & & $\begin{array}{l}\text { "I think I needed something more specific to write } \\
\text { about, instead of just my experience for the week." }\end{array}$ \\
\hline \multirow[t]{3}{*}{ Time } & \multirow[t]{3}{*}{5 responses } & "The only limitation is if you're in a time crunch." \\
\hline & & "limitation-wise, if you don’t have much time." \\
\hline & & "I put a lot of time into mine." \\
\hline \multirow[t]{2}{*}{ Technology } & \multirow[t]{2}{*}{4 responses } & $\begin{array}{l}\text { "I guess the big limitation for me was using } \\
\text { technology and learning how to import things into } \\
\text { the Weblogs." }\end{array}$ \\
\hline & & $\begin{array}{l}\text { “Um, I just, that wasn’t my ‘thing’. I still don’t do } \\
\text { emails very often. It’s just not my way of } \\
\text { accessing, I guess.” }\end{array}$ \\
\hline
\end{tabular}

When asked to identify limitations or barriers to writing their Weblogs, participants

indicated that they had difficulty selecting an appropriate case, among the patients they had seen during the week, to find evidence for and to present in their blog posts. They also indicated that the time involved in doing the assignment well was a barrier. Additionally, responses exposed issues related to using the Weblog technology. 
Table 10.

RQ1F: Barriers to Reading Weblogs Categories, Frequency Counts, \& Select Quotes.

\begin{tabular}{|c|c|c|}
\hline Category & $\begin{array}{l}\text { Frequency } \\
\text { Counts }\end{array}$ & Select Quotes \\
\hline \multirow[t]{2}{*}{ None } & \multirow[t]{2}{*}{6 responses } & $\begin{array}{l}\text { "I didn't have any limitations or barriers for } \\
\text { reading the Weblogs" }\end{array}$ \\
\hline & & $\begin{array}{l}\text { "I can't think of any limitations I had reading } \\
\text { others'.” }\end{array}$ \\
\hline \multirow[t]{4}{*}{$\begin{array}{l}\text { Lack of effort from } \\
\text { peers }\end{array}$} & \multirow[t]{4}{*}{5 responses } & $\begin{array}{l}\text { "those that actually, you know, you could tell took } \\
\text { the time to read the entire article and research what } \\
\text { they were doing rather than just you know, } \\
\text { skimming the article and picking out the key } \\
\text { points that they thought were important." }\end{array}$ \\
\hline & & $\begin{array}{l}\text { "I thought some of them were really good and } \\
\text { some of them really lacked effort." }\end{array}$ \\
\hline & & $\begin{array}{l}\text { "I would get really irritated when I would look and } \\
\text { see that someone used Wikipedia or something } \\
\text { that wasn’t empirical evidence.” }\end{array}$ \\
\hline & & $\begin{array}{l}\text { "if the person writing the Weblog had just kinda } \\
\text { done a website search instead of actually using a } \\
\text { published journal" }\end{array}$ \\
\hline
\end{tabular}

Regarding barriers to reading peer Weblogs, the majority of responses indicated that there were no barriers to reading blogs. However, several comments suggested that participants noticed blogs for which little effort had been made to complete the assignment and reacted negatively to these weak posts. 
Table 11.

RQ1G: Practices Learned Writing Weblogs Categories, Frequency Counts \& Select Quotes.

\begin{tabular}{|c|c|c|}
\hline \multicolumn{3}{|c|}{$\begin{array}{l}\text { 1G. Can you identify any specific clinical practices that you learned or found supported from the } \\
\text { evidence you uncovered when writing your blogs? Explain those for me, if affirmative }\end{array}$} \\
\hline Category & $\begin{array}{l}\text { Frequency } \\
\text { Counts }\end{array}$ & Select Quotes \\
\hline \multirow[t]{3}{*}{$\begin{array}{l}\text { Can identify specific } \\
\text { evidence }\end{array}$} & \multirow[t]{3}{*}{4 responses } & $\begin{array}{l}\text { "I can remember some VNG articles cause that's } \\
\text { usually what I'm lacking” }\end{array}$ \\
\hline & & "I did one on eNoG that really helped me" \\
\hline & & "real ear measures in one that really helped" \\
\hline \multirow{3}{*}{$\begin{array}{l}\text { Cannot identify any } \\
\text { specific evidence }\end{array}$} & \multirow[t]{3}{*}{4 responses } & "I don’t know that I can pinpoint any.” \\
\hline & & $\begin{array}{l}\text { "nothing specific that I can recall off the top of my } \\
\text { head" }\end{array}$ \\
\hline & & $\begin{array}{l}\text { "I don’t remember specifically what it was I } \\
\text { learned” }\end{array}$ \\
\hline
\end{tabular}

When asked if participants could identify specific clinical practices they had uncovered evidence to support, responses were evenly divided between those who could and those who could not. In a related question, participants were asked if they could identify specific clinical practices they learned from reading peers’ Weblogs. As indicated below in Table 12, the majority of responses indicated that they could not identify evidence-supported clinical practices, with only two responses identifying specific clinical practices supported. 
Table 12.

RQ1H: Practices Learned Reading Weblogs Categories, Frequency Counts, \& Select Quotes.

1H. Can you identify any specific clinical practices that you learned or found supported from evidence you read in another AuD student's blog?

\begin{tabular}{|c|c|c|}
\hline Category & $\begin{array}{l}\text { Frequency } \\
\text { Counts }\end{array}$ & Select Quotes \\
\hline \multirow[t]{2}{*}{$\begin{array}{l}\text { Cannot identify any } \\
\text { specific evidence }\end{array}$} & \multirow[t]{2}{*}{5 responses } & $\begin{array}{l}\text { "I know for sure that I learned from other people, I just } \\
\text { can’t remember specific client.” }\end{array}$ \\
\hline & & $\begin{array}{l}\text { "I know that I learned a bunch of stuff but I can’t } \\
\text { specifically say what I learned from the others'.” }\end{array}$ \\
\hline \multirow{2}{*}{$\begin{array}{l}\text { Can identify specific } \\
\text { evidence }\end{array}$} & \multirow[t]{2}{*}{2 responses } & “it was about cholesteatomas.” \\
\hline & & “some VNG articles” \\
\hline
\end{tabular}

The differences in responses to the two prior, related questions suggest that AuD students may retain evidence supporting clinical practices that they uncover themselves as compared to those they read in peer blog posts.

Research question 1 summary. Based on the participants' responses to the interview questions probing "What do AuD students learn about evidence-based practice from writing and reading clinic Weblogs,” AuD students imply that they did in fact learn how to locate and discuss evidence-based practice. They appeared to have learned the importance of applying evidence for the benefit of their clients. They described evidence-based practice (EBP) as applying evidence in their clinical practices and defined EBP based on sources of evidence. They indicated that they learned about EBP from the Weblog assignment - from peers as well as their own efforts. They were more able to identify evidence-supported clinical practices that they had uncovered themselves compared with those they read in peer blogs. They noticed when peers seemed to put less effort into their blogs and seemed to recognize weaknesses in sources selected to support peer blogs. They identified barriers to completing the blog assignment, as well. 
Analysis of blog content, however, did not support the premise that AuD students learned about evidence-based practice from reading and writing clinic Weblogs. Of the 396 blog posts that were analyzed, only 80 , or $20 \%$, contained some discussion of evidence-based practice. Because no assessment plan had been made for the Weblog assignment, there was no standard designated against which to compare the occurrence of discussion of EBP. KASA skills were evident throughout the blogs, however skill competencies could not be determine based on blog posts. None the less, a variety of clinical experiences could be observed.

\section{Research Question 2}

The second research question in my study asked: “What were AuD students’ reactions to writing and reading clinic Weblogs?” Six interview questions were asked of participants, in an attempt to answer this research question. The responses to these questions were transcribed and coded, and categories of responses emerged from the data. Tables 13 through 18 below display the categories of responses to the questions probing RQ2 along with the corresponding frequency counts and select quotes from interview responses. 
Table 13.

RQ2A: Initial Reactions to Weblog Assignment Categories, Frequency Counts, \& Select Quotes.

\begin{tabular}{|c|c|c|}
\hline Category & $\begin{array}{l}\text { Frequency } \\
\text { Counts }\end{array}$ & Select Quotes \\
\hline \multirow[t]{4}{*}{ Something else to do } & \multirow[t]{4}{*}{6 responses } & $\begin{array}{l}\text { "I honestly felt that it was just another thing to } \\
\text { do." }\end{array}$ \\
\hline & & $\begin{array}{l}\text { "I just thought it was one more thing to add on to } \\
\text { the pile." }\end{array}$ \\
\hline & & $\begin{array}{l}\text { "initial reaction was 'Oh god there’s something } \\
\text { else I have to do.'” }\end{array}$ \\
\hline & & "I was overwhelmed" \\
\hline \multirow[t]{2}{*}{ Didn’t want to do it } & \multirow[t]{2}{*}{4 responses } & "Well, I didn’t want to do it." \\
\hline & & $\begin{array}{l}\text { “My initial reaction was definitely like, “Ahhh! } \\
\text { What for?”” }\end{array}$ \\
\hline \multirow[t]{2}{*}{ Technology barriers } & \multirow[t]{2}{*}{4 responses } & $\begin{array}{l}\text { "I've never been the type of person that's } \\
\text { constantly on the Internet or anything like that, so. } \\
\text {. I think that was what differentiated me a little } \\
\text { bit." }\end{array}$ \\
\hline & & $\begin{array}{l}\text { "I couldn't remember how to get in there all the } \\
\text { time." }\end{array}$ \\
\hline
\end{tabular}

Participants were asked what their initial reactions to the Weblog assignment were. Participants stated that they felt the assignment was just something else that they had to do. Several responses indicated that participants did not want to do the assignment. Other respondents said that they experienced technological barriers such as inexperience with Webbased assignments and difficulty remembering access information to the blog. 
Table 14.

RQ2B: Change of Opinion Over Time Categories, Frequency Counts, \& Select Quotes

2B. Did you opinion of the assignment change over time?

\begin{tabular}{|c|c|c|}
\hline Category & $\begin{array}{l}\text { Frequency } \\
\text { Counts }\end{array}$ & Select Quotes \\
\hline \multirow[t]{3}{*}{ Opinion changed } & \multirow[t]{3}{*}{6 responses } & "Absolutely." \\
\hline & & "Yeah, definitely." \\
\hline & & "Yeah, it did because I did find it informative." \\
\hline \multirow[t]{3}{*}{$\begin{array}{l}\text { Considered it a large } \\
\text { effort }\end{array}$} & \multirow[t]{3}{*}{5 responses } & $\begin{array}{l}\text { "Just picking out specific clients and figuring out } \\
\text { what I was going to do, but as I did it over time, it } \\
\text { became easier." }\end{array}$ \\
\hline & & $\begin{array}{l}\text { "any time something's new, it's hard and you } \\
\text { don't want to do it and you don't want to figure it } \\
\text { out." }\end{array}$ \\
\hline & & $\begin{array}{l}\text { "Especially if you're doing what you're supposed } \\
\text { to actually sit down to do.” }\end{array}$ \\
\hline
\end{tabular}

When asked if their opinion of the assignment changed over time, the majority of responses were affirmative. Yet, participants indicated that the assignment required significant effort to complete properly. 
Table 15.

RQ2C: Favorite Aspect of the Blog Assignment Categories, Frequency Counts, \& Select Quotes

\begin{tabular}{|c|c|c|}
\hline \multicolumn{3}{|c|}{ 2C. What was your favorite aspect of the blog assignment? } \\
\hline Category & $\begin{array}{l}\text { Frequency } \\
\text { Counts }\end{array}$ & Select Quotes \\
\hline \multirow{3}{*}{$\begin{array}{l}\text { Liked reading peers' } \\
\text { blogs }\end{array}$} & \multirow[t]{3}{*}{5 responses } & “I would say reading everybody else’s.” \\
\hline & & $\begin{array}{l}\text { "being able to go in and read everyone’s } \\
\text { information and their thoughts on, on different } \\
\text { situations of their week in clinic." }\end{array}$ \\
\hline & & $\begin{array}{l}\text { "I liked to know that other people were having the } \\
\text { same experiences as me. It made me feel more } \\
\text { connected and not so alone with experiences" }\end{array}$ \\
\hline \multirow[t]{2}{*}{ Open to learning } & \multirow[t]{2}{*}{4 responses } & $\begin{array}{l}\text { "the ability to prepare ourselves for the real world } \\
\text { and how we would work with other audiologists in } \\
\text { the state is very important." }\end{array}$ \\
\hline & & $\begin{array}{l}\text { "if that involved criticism, then you know, my } \\
\text { feeling was 'so be it'. That's you know, } \\
\text { constructive criticism." }\end{array}$ \\
\hline \multirow[t]{2}{*}{$\begin{array}{l}\text { Liked personal } \\
\text { reflection }\end{array}$} & \multirow[t]{2}{*}{3 responses } & $\begin{array}{l}\text { "I think I just really liked uh, reflecting on the } \\
\text { interesting cases I saw during the week" }\end{array}$ \\
\hline & & $\begin{array}{l}\text { "To actually sit there and think, you know, this is } \\
\text { an interesting case - why did I do this?" }\end{array}$ \\
\hline
\end{tabular}

Most responses stated that participants’ favorite aspect of the assignment was reading blogs written by their peers. Other responses emerged around a theme of openness to learning. Specific quotes on this theme include a sense of preparation for life after graduation and accepting constructive criticism by peers (commenting on a blog post.) 
Table 16.

RQ2D: Least Favorite Aspect of the Assignment Categories, Frequency Counts, \& Select Quotes

2D. What was your lease favorite aspect of the blog assignment?

\begin{tabular}{|c|c|c|}
\hline Category & $\begin{array}{l}\text { Frequency } \\
\text { Counts }\end{array}$ & Select Quotes \\
\hline \multirow[t]{5}{*}{$\begin{array}{l}\text { Writing blog was } \\
\text { challenging }\end{array}$} & \multirow[t]{5}{*}{10 responses } & $\begin{array}{l}\text { "I had to come up with something kind of, you } \\
\text { wanted to be a little attention-getting so people } \\
\text { would want to read them," }\end{array}$ \\
\hline & & "Having to write my own" \\
\hline & & "Writing and researching them." \\
\hline & & $\begin{array}{l}\text { "like you sit there and ask around, like what can I } \\
\text { say that will peak interest here." }\end{array}$ \\
\hline & & $\begin{array}{l}\text { "really just trying to pick one or two experiences } \\
\text { out of a full week to talk about" }\end{array}$ \\
\hline
\end{tabular}

Overwhelmingly, participants said that the challenge associated with writing their blogs was their least favorite aspect of the assignment. Quotes from the transcripts indicate that the main challenge was finding an interesting case to research and write about. 
Table 17.

RQ2E: Recommendations For Blog Assignment Categories, Frequency Counts, \& Select Quotes

\begin{tabular}{|c|c|c|}
\hline Category & $\begin{array}{l}\text { Frequency } \\
\text { Counts }\end{array}$ & Select Quotes \\
\hline \multirow[t]{4}{*}{$\begin{array}{l}\text { More demonstration of } \\
\text { the assignment }\end{array}$} & \multirow[t]{4}{*}{6 responses } & $\begin{array}{l}\text { "it took awhile for you to get the point to everyone } \\
\text { that it was supposed to be a scholarly journal and a } \\
\text { published journal to support it instead of just a } \\
\text { website or, you know, just a webpage” }\end{array}$ \\
\hline & & $\begin{array}{l}\text { "maybe read them one of the more interesting ones } \\
\text { that you've had in the past" }\end{array}$ \\
\hline & & "I would probably want to do one as a group." \\
\hline & & $\begin{array}{l}\text { "what key words to use. I mean basically it was } \\
\text { just the practice. I don't know, I mean, maybe the } \\
\text { best search engines you could put up there you } \\
\text { know, this is where most of your articles can be } \\
\text { found. Or you know, maybe just specific web } \\
\text { bases or something to search.” }\end{array}$ \\
\hline \multirow[t]{3}{*}{ Specific requirements } & \multirow[t]{3}{*}{5 responses } & $\begin{array}{l}\text { "I think stricter is the wrong word, but having } \\
\text { more, something more specified," }\end{array}$ \\
\hline & & $\begin{array}{l}\text { "I think you'd really have to put your foot down } \\
\text { and say 'this is how it has to be done, this is, you } \\
\text { know, protocol of what you have to include," }\end{array}$ \\
\hline & & $\begin{array}{l}\text { "I think that would have helped me participate a } \\
\text { little bit more in it where we had uh, questions to } \\
\text { answer about each article." }\end{array}$ \\
\hline
\end{tabular}

Participants were asked what recommendations they would make [to me] regarding the Weblog assignment. The most frequent response was a request for more demonstration of the assignment, including doing a group blog post prior to doing individual blogs. Other responses called for specific requirements, such as defined guidelines or questions to answer. 
Table 18.

RQ2F: Other Blog Assignment Comments Categories, Frequency Counts, \& Select Quotes

\begin{tabular}{|c|c|c|}
\hline \multicolumn{3}{|c|}{$2 F$. Is there anything else about the blog assignment that you want to tell me? } \\
\hline Category & $\begin{array}{l}\text { Frequency } \\
\text { Counts }\end{array}$ & Select Quotes \\
\hline \multirow[t]{3}{*}{ Positive experience } & \multirow[t]{3}{*}{4 responses } & "I looked at it as a positive, positive endeavor." \\
\hline & & $\begin{array}{l}\text { "a couple of times I may have written something } \\
\text { that someone disagreed with and they brought out } \\
\text { a good point to it." }\end{array}$ \\
\hline & & $\begin{array}{l}\text { "I thought it was a good jump start and I think it's } \\
\text { a good idea now" }\end{array}$ \\
\hline \multirow[t]{2}{*}{ Didn’t want to } & \multirow[t]{2}{*}{3 responses } & $\begin{array}{l}\text { "I don't think any student wants to do anything } \\
\text { that's work." }\end{array}$ \\
\hline & & "I think for me it was just procrastinating," \\
\hline
\end{tabular}

My last question to participants in an attempt to answer what AuD students’ reactions were to writing and reading clinic Weblogs was an open-ended question. In response to asking if there was anything else about the blog assignment that they wanted to tell me, several comments were made that in general, the Weblog assignment was a positive experience, yet others reiterated that they still did not want to do the assignments at the time.

Survey results. Seven of my nine participants completed the anonymous Web-based survey. Two items in the Web-based survey addressed participants’ reactions to writing and reading clinic Weblogs. The reader is reminded that the link to the survey was emailed to all participants concurrently, six weeks after the last interview was completed. This interval was designated purposefully, in an attempt to gather authentic data as opposed to responses repeated from a recent interview. The survey was composed of nine Likert-type scale items. A five-point scale was used with points ranging from $1=$ strongly disagree through $5=$ strongly agree. Survey 
data was analyzed for item means as well as percentage of responses for individual items. Figure 3 illustrates means for Research Question 2 survey items.

Figure 3. RQ2 survey means results.

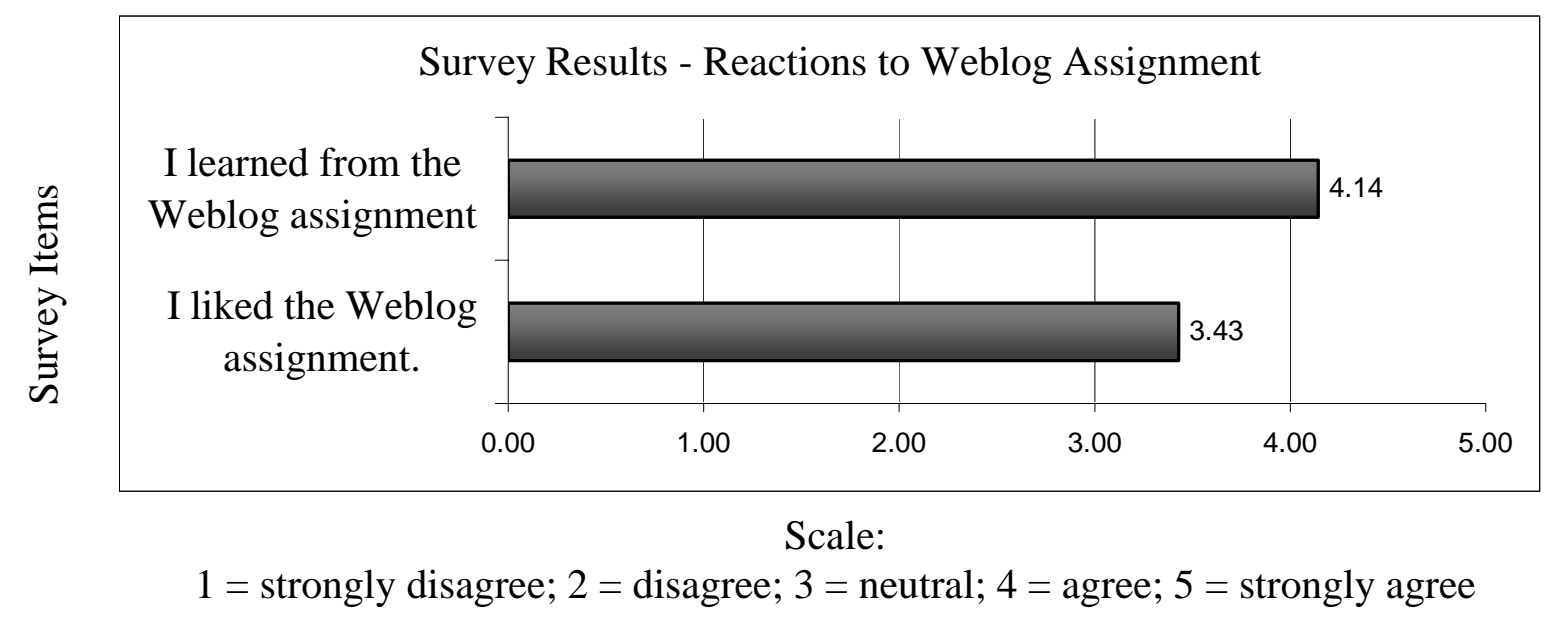

Mean results of the two survey items probing AuD students’ reactions to reading and writing clinic Weblogs are consistent with the trends identified from interview data. Participants agreed that they believed they learned from the Weblog assignment and held a more neutral position regarding liking the assignment.

Percentages of survey responses were calculated for individual survey items. Figure 4 illustrates positive responses to the item “I learned from the Weblog assignment.” 
Figure 4. I learned from the Weblog assignment.

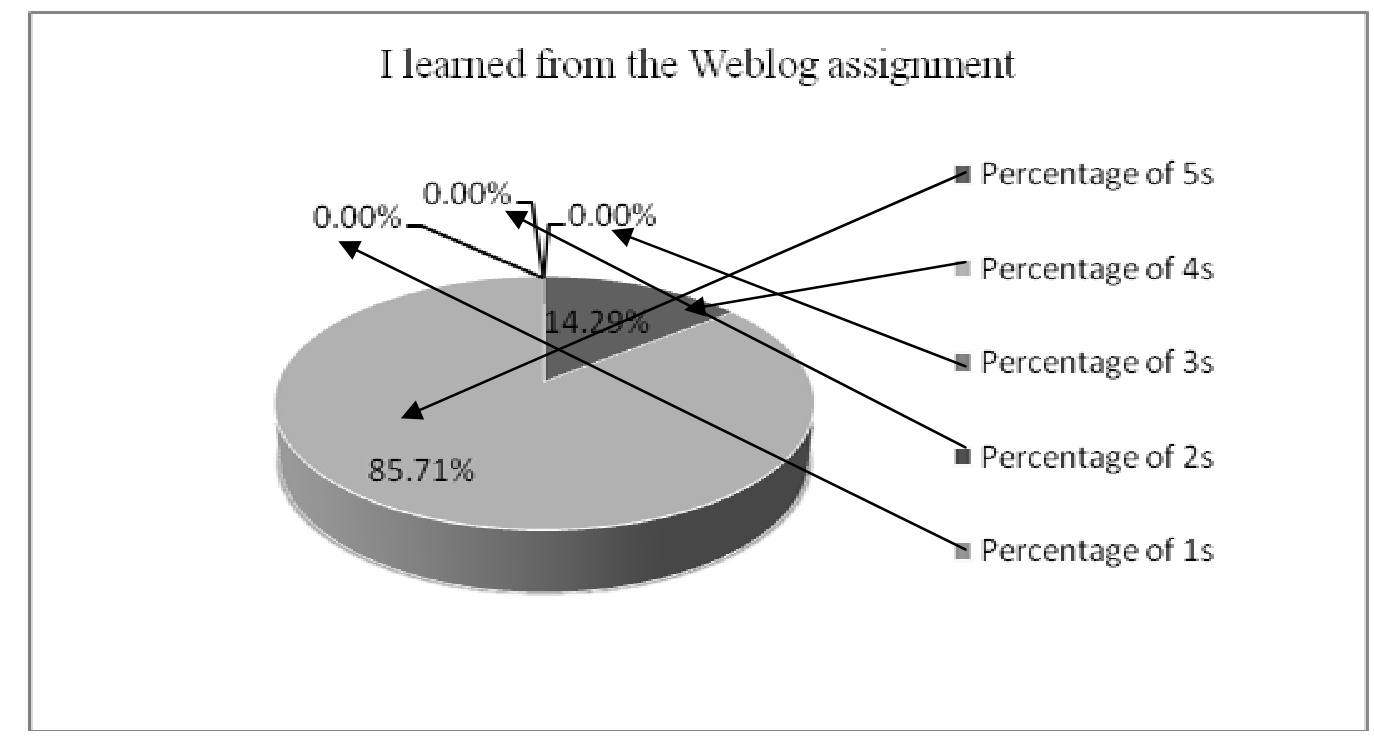

All responses to this statement were positive, with $85.71 \%$ strongly agreeing (5s) with the statement and $14.29 \%$ agreeing (4s) with it. While interview participants reported that they had learned from the Weblog assignment, this chart illustrates the strength of respondents' agreement that they learned from the assignment. No respondents ( $0 \%$ each) indicated a neutral response (3s), disagreement (2s), or strong disagreement (1s).

Percentages of survey responses to the item “I liked the Weblog assignment” are illustrated in Figure 5. 
Figure 5. I liked the Weblog assignment.

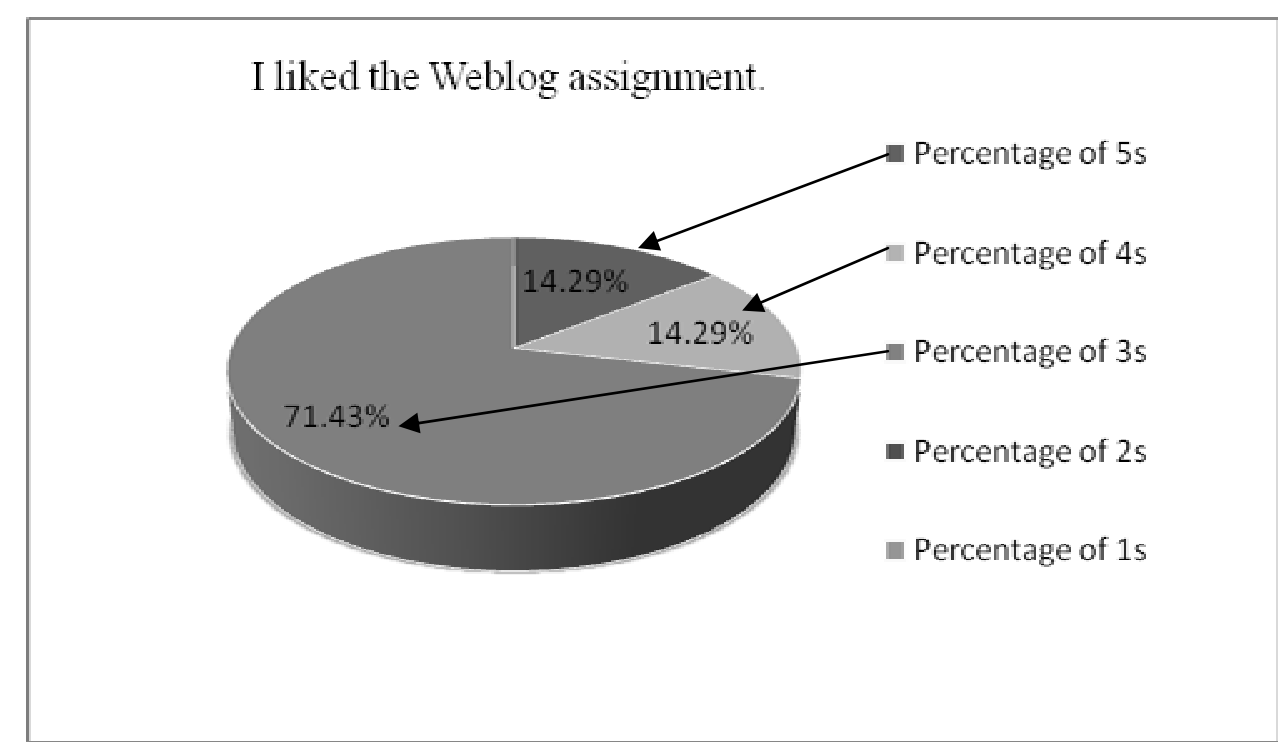

While all respondents agreed that they learned from the Weblog assignment, the majority of respondents (71.43\%) indicated a neutral response (3s) to the statement that they liked the assignment. The remaining percentage of responses was evenly split between agreement (4s) and strong agreement (5s) with 14.29\% each.

Research question 2 summary. Although most participants’ initial reactions to the Weblog assignment were negative, that opinion changed over time to more positive. Participants seemed to indicate that they learned from the Weblog assignment and became interested to read what peers were learning. However, the assignment seemed to remain a challenge to writing one's own blog and that finding something unique and interesting to write about was the largest challenge. Survey results confirmed that participants believed they learn more from the Weblog assignment than they liked it.

\section{Research Question 3}

The third research question in my study was to determine "What were AuD students' reactions to evidence-based practice?” As in Research Question 2 above, the answer to this 
question came from interview transcripts. Eleven questions were asked of participants in an attempt to answer Research Question 3. Again, the transcripts were coded for themes and categories of responses emerged from the data. Tables 19 through 29 display the categories and frequency counts as well as select quotes from responses to these eleven questions to determine AuD students' reactions to evidence-based practice.

Table 19.

RQ3A: EBP Learning From Courses Categories, Frequency Counts \& Select Quotes.

\begin{tabular}{|c|c|c|}
\hline Category & $\begin{array}{l}\text { Frequency } \\
\text { Counts }\end{array}$ & Select Quotes \\
\hline \multirow[t]{4}{*}{ General use of evidence } & \multirow[t]{4}{*}{5 responses } & $\begin{array}{l}\text { "professors would present information and then, } \\
\text { say, ask me why. And then if you said you didn't } \\
\text { know why, they would say well then you need to } \\
\text { research that and support what you're doing. So in } \\
\text { my courses, it was acknowledged that you need to } \\
\text { provide support and reasoning for what you're } \\
\text { doing with patients.” }\end{array}$ \\
\hline & & $\begin{array}{l}\text { "what is a strong um, evidence-supported article. } \\
\text { And what makes a weak one” }\end{array}$ \\
\hline & & $\begin{array}{l}\text { “" Prof X” was big on making sure you had } \\
\text { references outside of textbooks.” }\end{array}$ \\
\hline & & $\begin{array}{l}\text { "I think everything that we're taught is obviously } \\
\text { EBP," }\end{array}$ \\
\hline \multirow[t]{2}{*}{$\begin{array}{l}\text { Didn’t know how to } \\
\text { read research }\end{array}$} & \multirow[t]{2}{*}{4 responses } & $\begin{array}{l}\text { "in the beginning nobody really reads them } \\
\text { because you don't want to and half of it you really } \\
\text { don't understand" }\end{array}$ \\
\hline & & $\begin{array}{l}\text { “I remember saying to you even one day 'I can } \\
\text { read a whole research paper.' And I actually got } \\
\text { it.” }\end{array}$ \\
\hline
\end{tabular}

Participants suggested that their professors had been using evidence-based practice principles in general. Professors provided them readings in addition to textbooks and required 
students to be able to support clinical practices in the classroom. Participants also recognized that they didn't know how to consume research effectively early in their graduate program.

Table 20.

RQ3B: Learned EBP From Blog Assignment Categories, Frequency Counts \& Select Quotes.

3B. Did the blog assignment help you learn about evidence-based practice? How?

\begin{tabular}{|c|c|c|}
\hline Category & $\begin{array}{l}\text { Frequency } \\
\text { Counts }\end{array}$ & Select Quotes \\
\hline \multirow[t]{3}{*}{ Learned use of evidence } & \multirow[t]{3}{*}{4 responses } & $\begin{array}{l}\text { "know exactly why that test is valid for this } \\
\text { particular patient." }\end{array}$ \\
\hline & & $\begin{array}{l}\text { "helped me realize that you need to research these } \\
\text { things" }\end{array}$ \\
\hline & & $\begin{array}{l}\text { "we have our knowledge, we put it into play and } \\
\text { these are the possible outcomes. So um, you know, } \\
\text { by reading others examples, you know, I just got } \\
\text { more, uh, more input in my own uh, possible idea } \\
\text { of where it would go.” }\end{array}$ \\
\hline \multirow[t]{2}{*}{$\begin{array}{l}\text { Found sources of } \\
\text { evidence }\end{array}$} & \multirow[t]{2}{*}{3 responses } & $\begin{array}{l}\text { "how to search for good EBP article, and you } \\
\text { know, what to look for when it's not a true - you } \\
\text { know, when it’s just like an opinion that's out } \\
\text { there.” }\end{array}$ \\
\hline & & "helped me learn how to find answers." \\
\hline
\end{tabular}

Responses indicated that participants learned to use evidence for clinical practice and were able to find sources of evidence. The ability to find answers to clinical questions will enable AuD students to remain current in the profession and to continue to provide high quality care to their patients. 
Table 21.

RQ3C: Evidence-Based Practice Readings Categories, Frequency Counts \& Select Quotes.

3C. Have you read any journal articles or textbook information about evidence-based practice?

Tell me about what you've read.

\begin{tabular}{|c|c|c|}
\hline Category & $\begin{array}{l}\text { Frequency } \\
\text { Counts }\end{array}$ & Select Quotes \\
\hline \multirow[t]{3}{*}{ Specific evidence found. } & \multirow[t]{3}{*}{5 responses } & "the whole journal was based on evidence-based," \\
\hline & & $\begin{array}{l}\text { “especially stuff on BPPV, um, stuff on different } \\
\text { types of canilith remove-um, repositioning” }\end{array}$ \\
\hline & & $\begin{array}{l}\text { "had to do an EBP in your supervision course. I } \\
\text { think we read an article about it and I've read } \\
\text { some editorials about EBP }\end{array}$ \\
\hline \multirow[t]{3}{*}{ No readings on EBP } & \multirow[t]{3}{*}{4 responses } & $\begin{array}{l}\text { "I haven't seen anything current. And usually I } \\
\text { read a lot of the audiology magazines and } \\
\text { journals." }\end{array}$ \\
\hline & & “Not lately, I don’t think" \\
\hline & & $\begin{array}{l}\text { "outside of the stuff that we did for the blogs, I } \\
\text { haven't come into contact with any, no" }\end{array}$ \\
\hline
\end{tabular}

Responses were nearly evenly divided when it came to reading about evidence-based

practice in journals or textbooks. Only slightly fewer indicated that they had not read anything on the topic of evidence-based practice, yet one respondent recognized an issue of the Journal of the American Academy of Audiology which was wholly devoted to evidence-based practice in audiology. 
Table 22.

RQ3D: Specific Evidence Saved Categories, Frequency Counts \& Select Quotes.

3D. Have you saved any specific evidence that you think you may use in the future?

\begin{tabular}{|c|c|c|}
\hline Category & $\begin{array}{l}\text { Frequency } \\
\text { Counts }\end{array}$ & Select Quotes \\
\hline \multirow[t]{3}{*}{ Specific evidence saved } & \multirow[t]{3}{*}{7 responses } & $\begin{array}{l}\text { "But I have stuff. I have everything I ever worked } \\
\text { on.” }\end{array}$ \\
\hline & & $\begin{array}{l}\text { "I remember one in particular that it was like a } \\
\text { "Wow", um, that I hadn't read before. That after } \\
\text { you do the Epley maneuver for BPPV it is not } \\
\text { necessary to wear a neck brace or sit upright" }\end{array}$ \\
\hline & & $\begin{array}{l}\text { "I gathered as much information that I possibly } \\
\text { could get to have. Um, especially stuff on BPPV" }\end{array}$ \\
\hline \multirow[t]{2}{*}{ Scholarly work } & \multirow[t]{2}{*}{3 responses } & “Yes, for my scholarly work” \\
\hline & & "Stuff on what I'm doing for my scholarly work." \\
\hline
\end{tabular}

Participants indicated that they had in fact saved material they consider evidence for future use, some of which were being used for the students' scholarly work requirement of their programs. Evidence regarding a specific balance disorder appeared in several responses. 
Table 23.

RQ3E: Thoughts of Implementing EBP Categories, Frequency Counts \& Select Quotes.

\begin{tabular}{|c|c|c|}
\hline \multicolumn{3}{|c|}{$\begin{array}{l}\text { 3E. Have you thought about how you will implement evidence-based practice when working as } \\
\text { an audiologist? }\end{array}$} \\
\hline Category & $\begin{array}{l}\text { Frequency } \\
\text { Counts }\end{array}$ & Select Quotes \\
\hline \multirow{3}{*}{$\begin{array}{l}\text { Have thought about } \\
\text { applying EBP }\end{array}$} & \multirow[t]{3}{*}{5 responses } & "I support everything that I do with research.” \\
\hline & & $\begin{array}{l}\text { "I think I do use EBP. I do research information if } \\
\text { I'm not sure and try to find the best information } \\
\text { out there on a subject." }\end{array}$ \\
\hline & & $\begin{array}{l}\text { "Yeah, I mean I definitely being in the positions } \\
\text { that I am, I definitely have to be on guard and be } \\
\text { able to explain anything at any time. I even have } \\
\text { PT's that I talk to and um, we give articles back } \\
\text { and forth" }\end{array}$ \\
\hline \multirow[t]{2}{*}{$\begin{array}{l}\text { Current sources of } \\
\text { evidence }\end{array}$} & \multirow[t]{2}{*}{4 responses } & $\begin{array}{l}\text { "I get to find out new and interesting things and } \\
\text { um, go to conferences, and get experience - um, } \\
\text { seminars, and get continuing education, and } \\
\text { constantly finding things interesting." }\end{array}$ \\
\hline & & $\begin{array}{l}\text { "right now, my main resources are the internet, } \\
\text { which mainly is journal articles and what people } \\
\text { have published. And journal articles that I get, um, } \\
\text { regular journals in the mail" }\end{array}$ \\
\hline \multirow{2}{*}{$\begin{array}{l}\text { No thoughts on applying } \\
\text { EBP }\end{array}$} & \multirow[t]{2}{*}{3 responses } & "No I have not honestly thought about that." \\
\hline & & “No, I can’t say that I have” \\
\hline
\end{tabular}

Several participants indicated that they do apply evidence-based practice principles currently in their professional work. Comments were made about current activities that serve as sources of evidence. Surprisingly, a third of participants indicated that they have not given any thought to incorporating EBP principles into their clinical practices. 
Table 24.

RQ3F: Teaching EBP in AuD Programs Categories, Frequency Counts \& Select Quotes.

\begin{tabular}{|c|c|c|}
\hline \multicolumn{3}{|c|}{ 3F. How do you think evidence-based practice should be taught in AuD programs? } \\
\hline Category & $\begin{array}{l}\text { Frequency } \\
\text { Counts }\end{array}$ & Select Quotes \\
\hline \multirow{4}{*}{$\begin{array}{l}\text { Already being taught } \\
\text { EBP, even if not called } \\
\text { EBP }\end{array}$} & \multirow[t]{4}{*}{7 responses } & $\begin{array}{l}\text { "I think that we're doing that. It just doesn't come } \\
\text { out as EBP - you know, those words." }\end{array}$ \\
\hline & & $\begin{array}{l}\text { "I’ve been taught EBP from day-one of graduate } \\
\text { school but it’s not conveyed in those terms.” }\end{array}$ \\
\hline & & $\begin{array}{l}\text { "I think it is being taught throughout all the } \\
\text { classes. It's just not being stated as being taught } \\
\text { EBP.” }\end{array}$ \\
\hline & & $\begin{array}{l}\text { "I think it is. It might not be specifically stated as } \\
\text { using EBP. But I mean I think it always is in some } \\
\text { shape or form because we look up the research, we } \\
\text { have um, quoted research behind a lot of what we } \\
\text { do, why to choose this procedure and why we use } \\
\text { the procedure" }\end{array}$ \\
\hline \multirow[t]{3}{*}{$\begin{array}{l}\text { Should be in every } \\
\text { course /class }\end{array}$} & \multirow[t]{3}{*}{4 responses } & $\begin{array}{l}\text { "I think it should be an integral part of every } \\
\text { class." }\end{array}$ \\
\hline & & $\begin{array}{l}\text { "every professor or you know, every level is going } \\
\text { to have to start implementing it in some way or the } \\
\text { other." }\end{array}$ \\
\hline & & $\begin{array}{l}\text { "every professor should step and make some kind } \\
\text { of point and try to squeeze it in there, even if it's } \\
\text { just uh, one afternoon or something.” }\end{array}$ \\
\hline \multirow[t]{2}{*}{$\begin{array}{l}\text { Students don't } \\
\text { understand research }\end{array}$} & \multirow[t]{2}{*}{4 responses } & $\begin{array}{l}\text { “just even how to read the graphs and stuff in } \\
\text { those. That sounds crazy too, but like you really } \\
\text { just don’t get it for a while.” }\end{array}$ \\
\hline & & $\begin{array}{l}\text { "it's hard and the reason I think it's hard is } \\
\text { because you don't get it. You really just don't get } \\
\text { it.” }\end{array}$ \\
\hline
\end{tabular}

When asked how they thought EBP should be taught in AuD programs, the majority of responses indicated that students believed they had been taught EBP principles, although the term "evidence-based practice” had not been used. Other responses suggested that EBP 
principles should be incorporated into every course in some manner. The difficulty AuD students have learning to read research was reiterated in response to this question, as well.

Table 25.

RQ3G: Teaching EBP in WVU's AuD Program Categories, Frequency Counts \& Select Quotes.

\begin{tabular}{|c|c|c|}
\hline Category & $\begin{array}{l}\text { Frequency } \\
\text { Counts }\end{array}$ & Select Quotes \\
\hline \multirow[t]{4}{*}{$\begin{array}{l}\text { Help students } \\
\text { understand research }\end{array}$} & \multirow[t]{4}{*}{12 responses } & $\begin{array}{l}\text { "We get them free as students - nobody knows } \\
\text { how to read those" }\end{array}$ \\
\hline & & $\begin{array}{l}\text { "learning how to read articles and really knowing } \\
\text { what they say is important." }\end{array}$ \\
\hline & & $\begin{array}{l}\text { “my first introduction to any research period, you } \\
\text { know, actually doing it and understanding it was } \\
\text { when I wasn’t at school” }\end{array}$ \\
\hline & & $\begin{array}{l}\text { "Nobody teaches you how to read a journal or a } \\
\text { scientific journal or, you know, nobody teaches } \\
\text { you how to read those.” }\end{array}$ \\
\hline \multirow[t]{4}{*}{$\begin{array}{l}\text { More exposure to EBP } \\
\text { in clinics }\end{array}$} & \multirow[t]{4}{*}{6 responses } & $\begin{array}{l}\text { “just expose students a little bit more. And that's } \\
\text { not just Allen Hall, that’s every where.” }\end{array}$ \\
\hline & & $\begin{array}{l}\text { "If you have a question, instead of the supervisor } \\
\text { answering it, say "Why don't you look that up and } \\
\text { tell me what you find out." Maybe once a week, or } \\
\text { something like that" }\end{array}$ \\
\hline & & $\begin{array}{l}\text { "some clinic sites that I think could step up and } \\
\text { say, you know, 'let's go by the book'.” }\end{array}$ \\
\hline & & $\begin{array}{l}\text { "that could even be implemented into everyday } \\
\text { clinics.” }\end{array}$ \\
\hline \multirow[t]{3}{*}{ Technology use } & \multirow[t]{3}{*}{6 responses } & $\begin{array}{l}\text { "maybe something online where they have to } \\
\text { research good articles and say why they’re good," }\end{array}$ \\
\hline & & $\begin{array}{l}\text { "the continuation of any sort of technological um, } \\
\text { you know, implementation" }\end{array}$ \\
\hline & & $\begin{array}{l}\text { "blogging is pretty helpful in teaching you about } \\
\text { it." }\end{array}$ \\
\hline
\end{tabular}


In response to my question asking how participants thought evidence-based practice should be taught in our AuD program, a significant number of responses indicated that participants thought AuD students should be taught how to read and understand research purposefully. They also responded that students should be exposed to evidence-based practice in their clinical practicum more regularly. Additionally, participants indicated that technology should be used to facilitate consumption of research and learning of evidence-based practice. Table 26.

RQ3H: Recommendations for EBP in Weblogs Categories, Frequency Counts \& Select Quotes.

\begin{tabular}{|c|c|c|}
\hline $\begin{array}{l}\text { 3H. What recommendat } \\
\text { component of the Weblc }\end{array}$ & $\begin{array}{l}\text { ns would you m } \\
\text { assignment? }\end{array}$ & with regards to the evidence-based practice \\
\hline Category & $\begin{array}{l}\text { Frequency } \\
\text { Counts }\end{array}$ & Select Quotes \\
\hline $\begin{array}{l}\text { Emphasize importance } \\
\text { of EBP }\end{array}$ & 3 responses & $\begin{array}{l}\text { "The reason I learned was just because I saw it on } \\
\text { the Praxis, I'm doing it in clinic every day." }\end{array}$ \\
\hline & & $\begin{array}{l}\text { “need to understand this cause when you're out at } \\
\text { a clinic site and someone asks you 'hey, why are } \\
\text { you doing this?’” }\end{array}$ \\
\hline Clear expectations & 3 responses & $\begin{array}{l}\text { "just some guidance in how to look and how to } \\
\text { look, or where to look for good researched } \\
\text { articles.” }\end{array}$ \\
\hline & & $\begin{array}{l}\text { "Making specific minimum requirements for } \\
\text { people to meet” }\end{array}$ \\
\hline $\begin{array}{l}\text { Student responsibility } \\
\text { for their learning }\end{array}$ & 3 responses & $\begin{array}{l}\text { "I just think the students need to care a little bit } \\
\text { more." }\end{array}$ \\
\hline & & $\begin{array}{l}\text { "it's something you have to do for yourself. If you } \\
\text { can't motivate yourself to do it, then who can?" }\end{array}$ \\
\hline
\end{tabular}

Participants were asked if they had recommendations regarding the evidence-based practice component of the Weblog assignment. Three categories emerged with equal frequency: emphasize the importance of EBP, provide clear expectations of the assignment, and students' roles in taking responsibility for their own learning. 
Table 27.

RQ3I: More Course Exposure to EBP Categories, Frequency Counts \& Select Quotes.

\begin{tabular}{|c|c|c|}
\hline Category & $\begin{array}{l}\text { Frequency } \\
\text { Counts }\end{array}$ & Select Quotes \\
\hline \multirow[t]{4}{*}{$\begin{array}{l}\text { Emphasize reason for } \\
\text { EBP }\end{array}$} & \multirow[t]{4}{*}{7 responses } & $\begin{array}{l}\text { "I think if we knew that there was a reasoning } \\
\text { behind what we were doing and why we were } \\
\text { mixing our personal experience with research and } \\
\text { some foundation to what we were doing" }\end{array}$ \\
\hline & & $\begin{array}{l}\text { "any subject you take in an AuD program could } \\
\text { always go into more if you need to" }\end{array}$ \\
\hline & & $\begin{array}{l}\text { "if you're in the middle of the medical field } \\
\text { somewhere, you better have it" }\end{array}$ \\
\hline & & $\begin{array}{l}\text { "would have been a good thing to, you know, keep } \\
\text { going when we graduate so we would know what } \\
\text { to do when we actually had to do it on our own" }\end{array}$ \\
\hline \multirow[t]{2}{*}{ Ways to use in courses } & \multirow[t]{2}{*}{4 responses } & $\begin{array}{l}\text { "examples should be provided about how things } \\
\text { were done for many years and then were proved to } \\
\text { be ineffective or there's a better way to do it" }\end{array}$ \\
\hline & & $\begin{array}{l}\text { "having us read more article and kind of figure out } \\
\text { how to implement it into clinic" }\end{array}$ \\
\hline
\end{tabular}

When asked if they thought that more needed to be done in their graduate courses to expose them to EBP, participants stated that they believed an emphasis on the reasons why evidence-based practice principles should be applied would be important in courses. Suggestions were offered on ways EBP could be used in courses, such as giving examples of how evidence changed clinical practices in the past and assignments similar to the clinic Weblog assignment. 
Table 28.

RQ3J: More Clinic Practicum Exposure to EBP Categories, Frequency Counts \& Select Quotes.

\begin{tabular}{|c|c|c|}
\hline \multicolumn{3}{|c|}{$\begin{array}{l}\text { 3J. Does/did more need to be done in your clinical practicum to expose you to evidence-based } \\
\text { practice? }\end{array}$} \\
\hline Category & $\begin{array}{l}\text { Frequency } \\
\text { Counts }\end{array}$ & Select Quotes \\
\hline \multirow[t]{3}{*}{$\begin{array}{l}\text { Want more exposure in } \\
\text { clinical practicum }\end{array}$} & \multirow[t]{3}{*}{6 responses } & $\begin{array}{l}\text { "have more information and more supervisors } \\
\text { stressing the importance of it." }\end{array}$ \\
\hline & & $\begin{array}{l}\text { "it would be nice to be exposed to it a little bit } \\
\text { more." }\end{array}$ \\
\hline & & $\begin{array}{l}\text { "not how you do it, you know, per se, but you } \\
\text { know, why you would do this. I think that there } \\
\text { was a little bit of a lag there.” }\end{array}$ \\
\hline \multirow[t]{3}{*}{$\begin{array}{l}\text { Have observed evidence } \\
\text { ignored in clinic }\end{array}$} & \multirow[t]{3}{*}{5 responses } & $\begin{array}{l}\text { "When you fit a hearing aid on a child and you just } \\
\text { use Best Fit on the software, that's not EBP - } \\
\text { that's trying to save time" }\end{array}$ \\
\hline & & “a lot of people take short cuts sometimes.” \\
\hline & & $\begin{array}{l}\text { "some places could step up and say, you know, } \\
\text { 'this is what we're dong, this is why we're doing } \\
\text { it.”' }\end{array}$ \\
\hline \multirow[t]{3}{*}{ Want EBP modeled } & \multirow[t]{3}{*}{4 responses } & $\begin{array}{l}\text { "but they do it without involving us. We're just } \\
\text { mainly there to observe and help out and do the } \\
\text { fundamentals. And it would be nice to know what } \\
\text { they do when we're not there” }\end{array}$ \\
\hline & & $\begin{array}{l}\text { "I think they do it too - I would hope so - that } \\
\text { they were keeping up with information and } \\
\text { keeping up with the journal articles, and all the } \\
\text { research." }\end{array}$ \\
\hline & & $\begin{array}{l}\text { "some supervisors did stress the importance of you } \\
\text { know, why we do things" }\end{array}$ \\
\hline
\end{tabular}

Participants indicated that they would have liked more exposure to EBP in their clinical practicum, with supervisors reinforcing the practice. They also were able to identify clinic experiences where evidence-based practices had been ignored with some patients/clients. Not 
surprisingly, they also stated that they would liked to have seen EBP modeled for them more in their clinical experiences.

Table 29.

RQ3K: Other EBP Comments Categories, Frequency Counts \& Select Quotes.

\begin{tabular}{|c|c|c|}
\hline Category & $\begin{array}{l}\text { Frequency } \\
\text { Counts }\end{array}$ & Select Quotes \\
\hline \multirow[t]{4}{*}{$\begin{array}{l}\text { More exposure to EBP } \\
\text { needed }\end{array}$} & \multirow[t]{4}{*}{5 responses } & $\begin{array}{l}\text { "But when new things come out, I think you know, } \\
\text { we could get a copy of it, or be told this is where } \\
\text { you need to go get it. And actually be made to read } \\
\text { it." }\end{array}$ \\
\hline & & $\begin{array}{l}\text { "there wasn’t a huge amount of it in our } \\
\text { schooling” }\end{array}$ \\
\hline & & $\begin{array}{l}\text { "I definitely don't think we were as prepared as we } \\
\text { needed to be even when we were going off to do } \\
\text { our fourth year" }\end{array}$ \\
\hline & & "It's a pain to read but it’s very helpful” \\
\hline \multirow[t]{3}{*}{$\begin{array}{l}\text { Need to see EBP } \\
\text { modeled }\end{array}$} & \multirow[t]{3}{*}{4 responses } & $\begin{array}{l}\text { "I had a good teacher when I left and was very } \\
\text { patient with me and literally took every second } \\
\text { with me that I possible wanted to help me get } \\
\text { through everything” }\end{array}$ \\
\hline & & $\begin{array}{l}\text { “everything was so focused on 'why do you do } \\
\text { this?', 'why do you do this?'” }\end{array}$ \\
\hline & & $\begin{array}{l}\text { "they’re constantly doing research, constantly } \\
\text { writing papers.” }\end{array}$ \\
\hline \multirow[t]{2}{*}{$\begin{array}{l}\text { Support application of } \\
\text { EBP }\end{array}$} & \multirow[t]{2}{*}{4 responses } & $\begin{array}{l}\text { "the journal articles and you sort of have to take } \\
\text { that information and combine it and figure out } \\
\text { what would be best for your patient." }\end{array}$ \\
\hline & & $\begin{array}{l}\text { "So when they do graduate, they don't just leave } \\
\text { with the knowledge that they graduated with and } \\
\text { not continue learning and continuing researching } \\
\text { things.” }\end{array}$ \\
\hline
\end{tabular}


Finally, participants were asked to give any additional comments about evidence-based practice. The responses reiterated earlier responses favoring more exposure to EBP, more modeling of EBP, and support of applying EBP principles.

Research question 3 survey results. Again, seven of my nine participants completed the anonymous Web-based survey. To remind the reader, the survey was composed of nine Likerttype scale items. A five-point scale was used with points ranging from $1=$ strongly disagree through $5=$ strongly agree. Survey data was analyzed for item means as well as percentage of responses for individual items. Figure 6 below illustrates means for research question 3 survey items.

Figure 6. RQ3 survey means results.

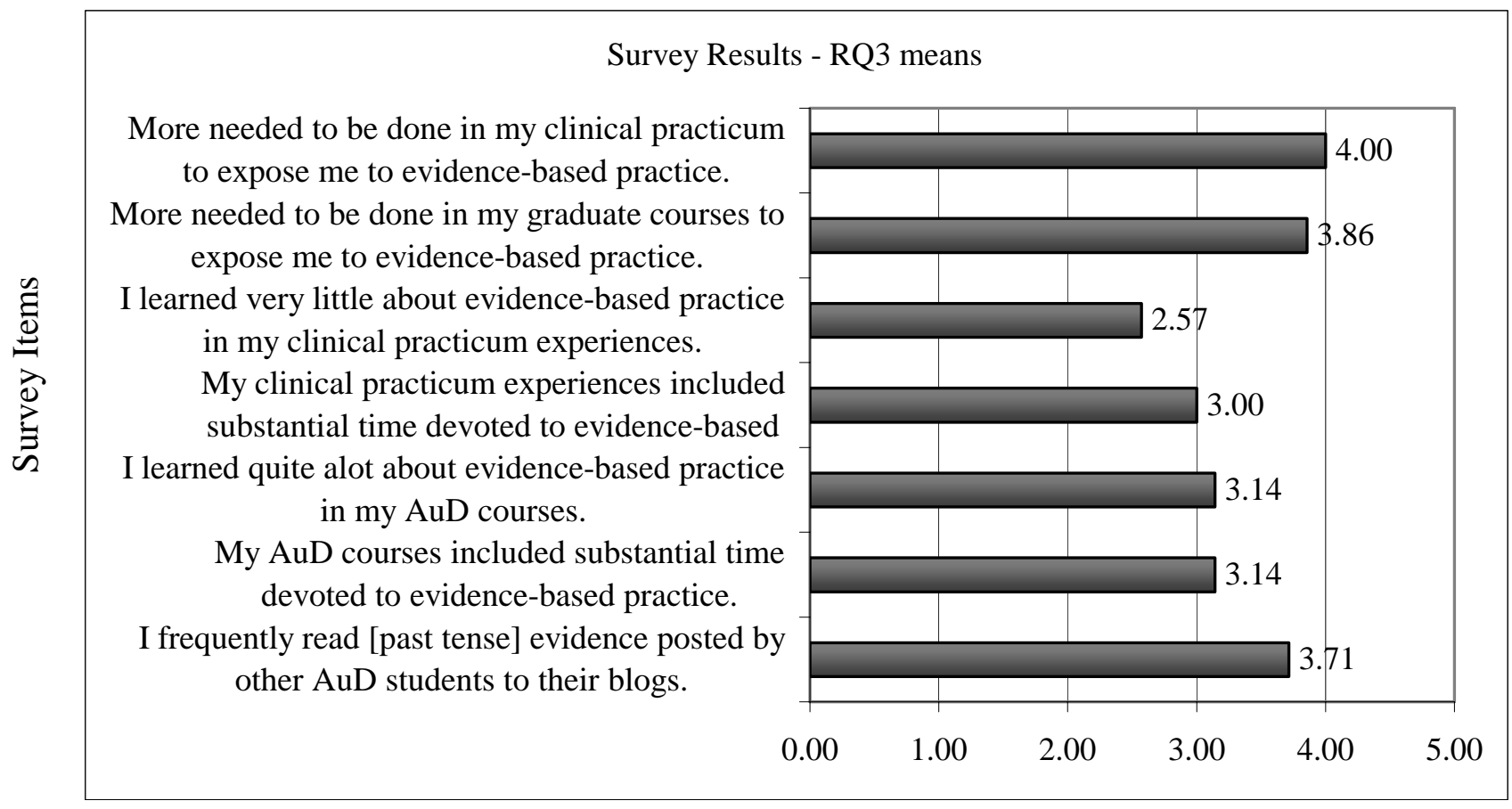

Scale:

1 = strongly disagree; 2 = disagree; 3 = neutral; 4 = agree; 5 = strongly agree 
Percentages of survey responses were calculated for individual survey items. Figure 7 illustrates positive responses to the item "more needed to be done in my clinical practicum to expose me to evidence-based practice.

Figure 7. Needed more clinical practicum exposure to EBP.

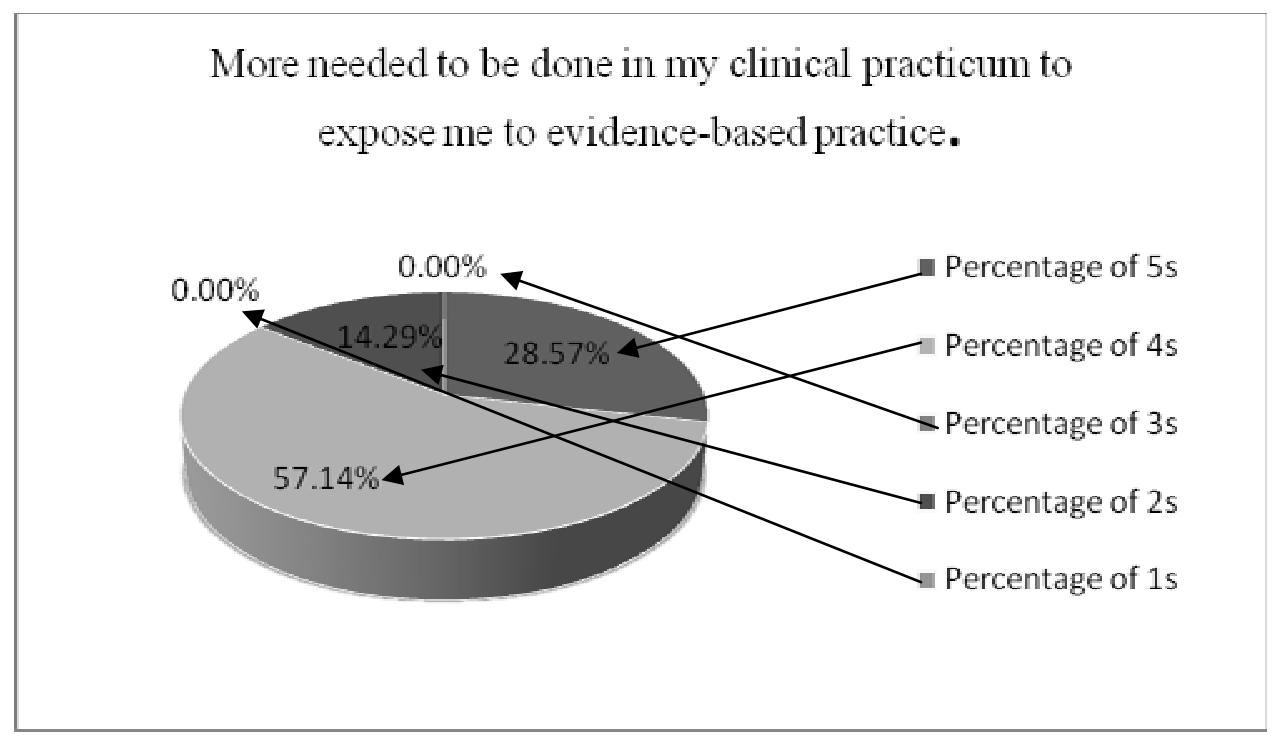

The major percentage of responses to the item "More needed to be done in my clinical practicum to expose me to evidence-based practice” was 4 (agree) with $57.14 \%$ of the responses, followed by $28.57 \%$ or responses marked as 5 (strongly agree) and $14.29 \%$ of responses indicated as 2 (disagree). These findings are consistent with interview data in which participants stated that they wanted more exposure to evidence-based practice during their clinical practicum. Sample quotes from the interview data include "have more information and more supervisors stressing the importance of it” and "it would be nice to be exposed to it a little bit more." 
Figure 8. Needed more graduate course EBP exposure.

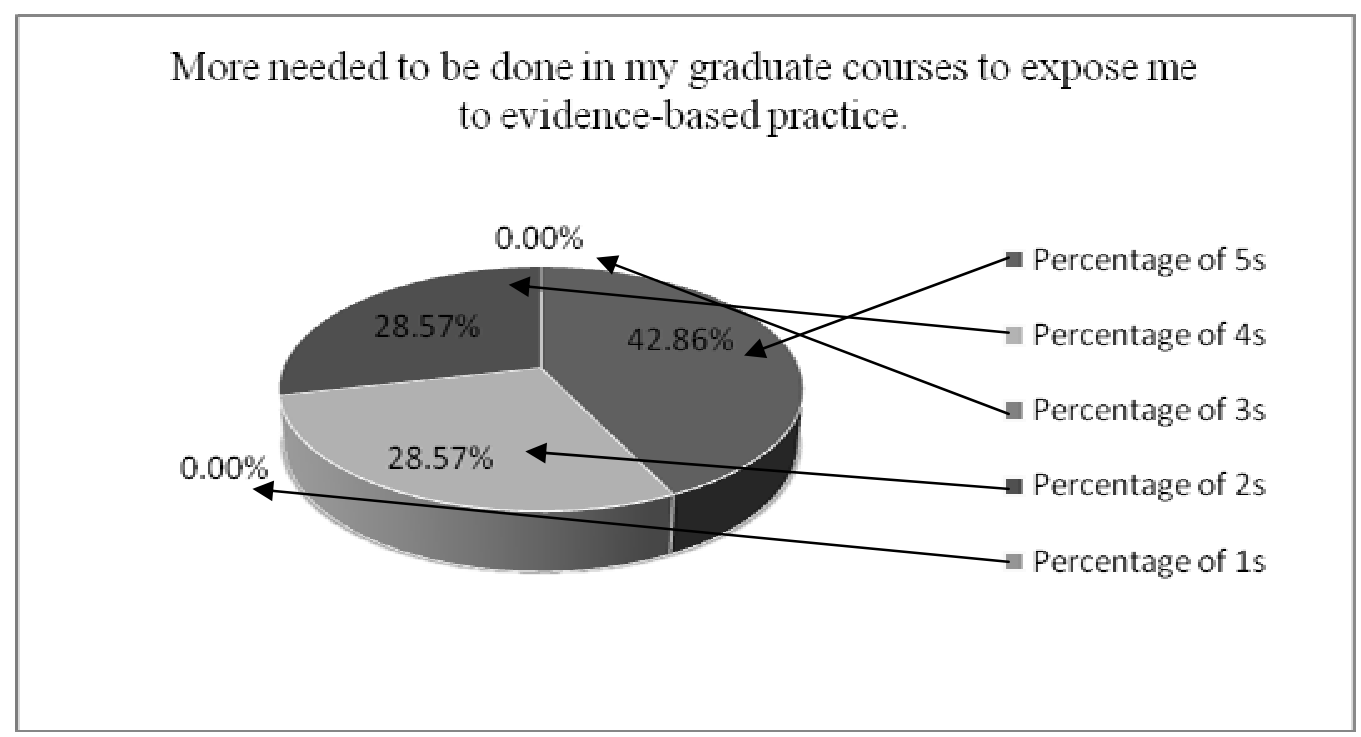

Forty-two percent of responses strongly agreed (5s) with the statement that "More needed to be done in my graduate courses to expose me to evidence-based practice.” The remaining percentage of responses was evenly divided between agree (4s) and disagree (2s) with $28.57 \%$ each. When compared with interview data, participants had stated that they had been taught evidence-based principles and were given sources of evidence in their courses. However the term “evidence-based practice” had not been used in the classroom. 
Figure 9. I learned very little EBP in clinical practicum.

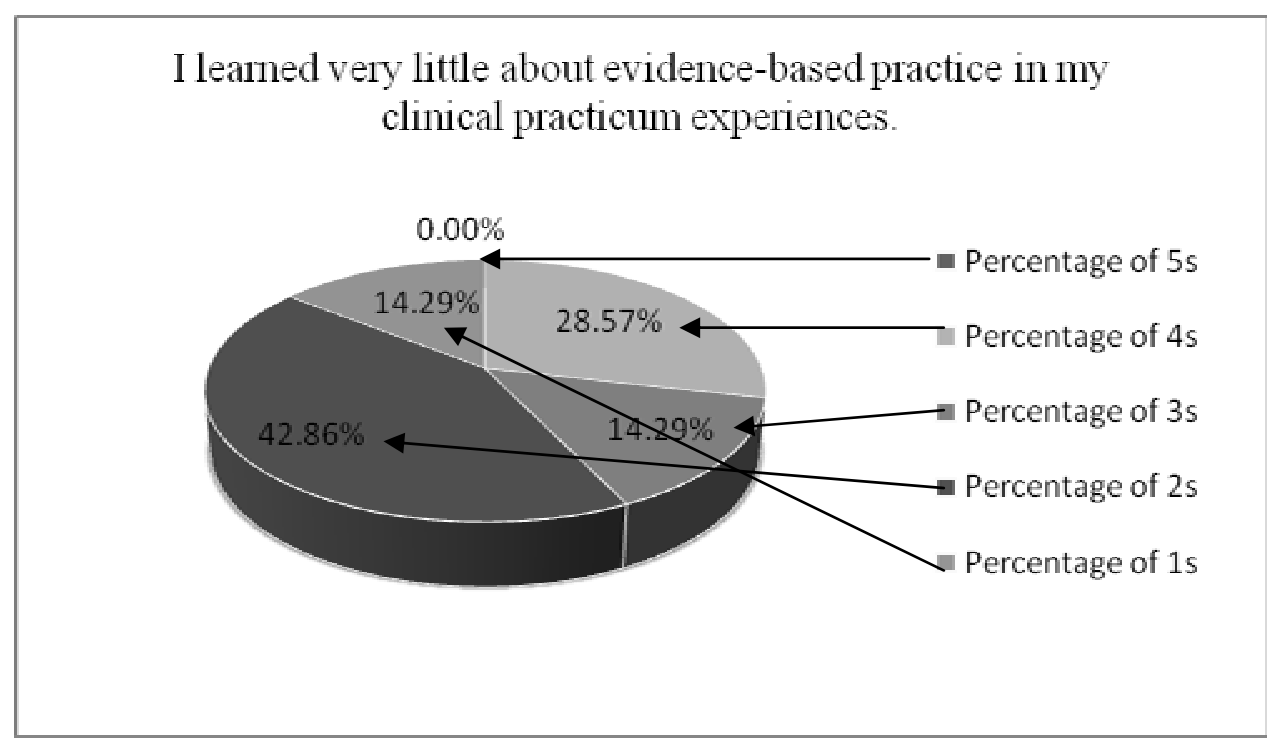

The majority (42.86\%) of respondents disagreed (2s) with this negative item, suggesting that they did learn about EBP in their clinical practicum. Similarly, 14.29\% strongly disagreed (1s) with the statement. However, $28.57 \%$ of responses agreed (4s) that they learned very little about EBP in their clinical practicum and 14.29\% gave a neutral response (3s). This item was written in the negative voice. Therefore, participants who believed that they did learn from the Weblog assignment would have disagreed with the statement. While the majority did disagree with the item, that was not true for all respondents. Interview questions did not address the same question, therefore direct comparison cannot be made to this statement. 
Figure 10. Substantial time devoted to EBP in clinical practicum.

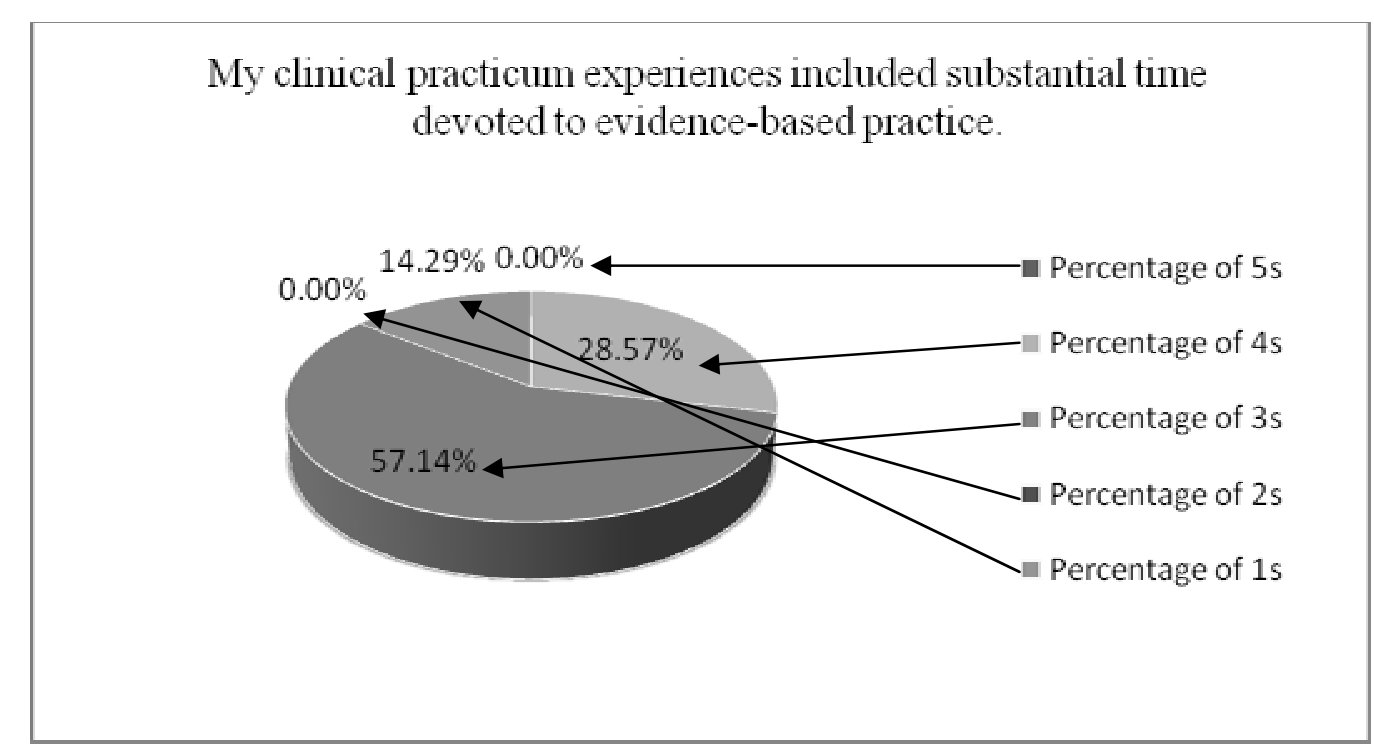

Neutral responses (3s) were observed to the item "My clinical practicum experiences included substantial time devoted to evidence-based practice” in $57.14 \%$ of responses. $14.29 \%$ strongly disagreed (1s) with the statement, while more (28.57\%) agreed (or rating 4) with the statement. None of the respondents disagreed (2s) or strongly agreed (5s) with the item. More exposure to evidence-based practice in clinics was a primary category that emerged from the qualitative analysis of the interview data. Interviewees were asked what recommendations they had for teaching EBP to AuD students. This interview category and the percentage of responses to this survey question lend support to each other. 
Figure 11. I learned quite a lot about EBP in my AuD courses.

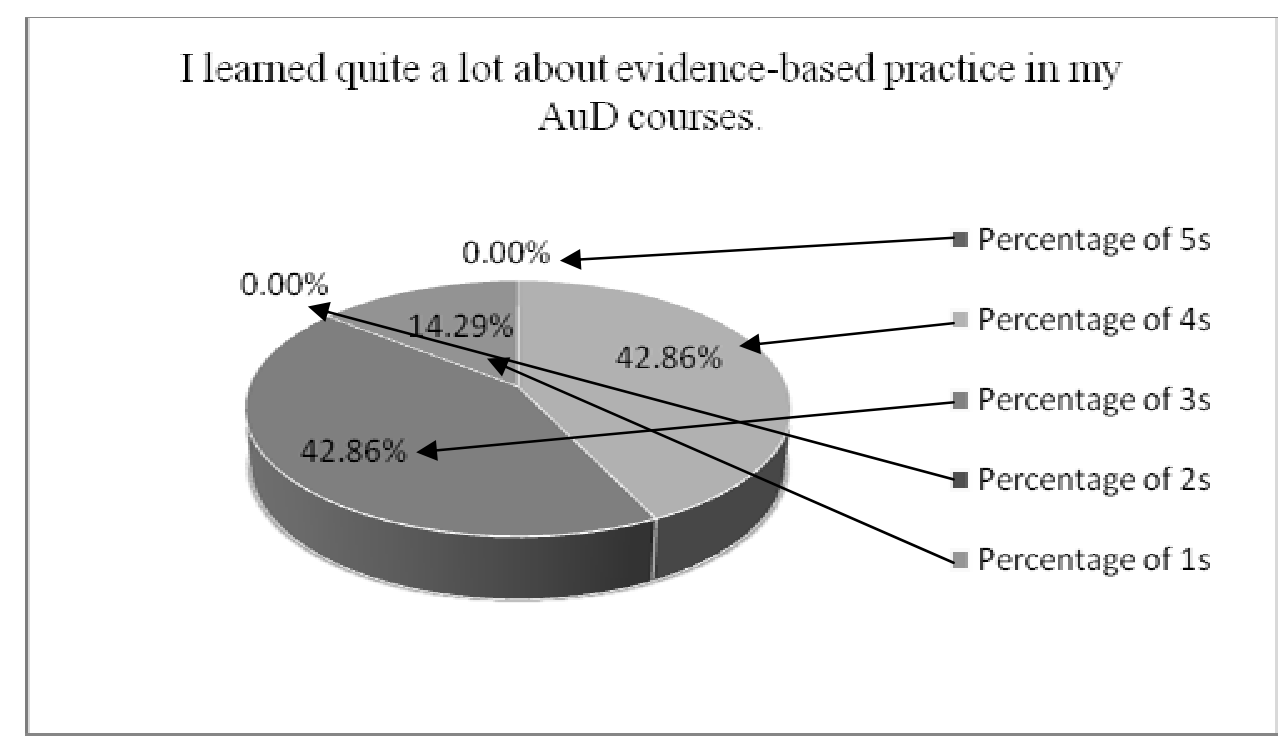

Participants, for the most part, were evenly divided between neutral responses (3s) and agreement (4s) with $42.86 \%$ of responses each to the statement "I learned quite a lot about evidence-based practice in my AuD courses.” A smaller percentage (14.29\%) strongly disagree that they had learned quite a lot about EBP in their AuD courses (scale rating of 1). Again, when compared with interview categories, participants had stated that, in retrospect, they had learned from audiological evidence in their courses but were not familiar with the term "evidence-based practice.” 
Figure 12. Substantial time devoted to EBP in AuD courses.

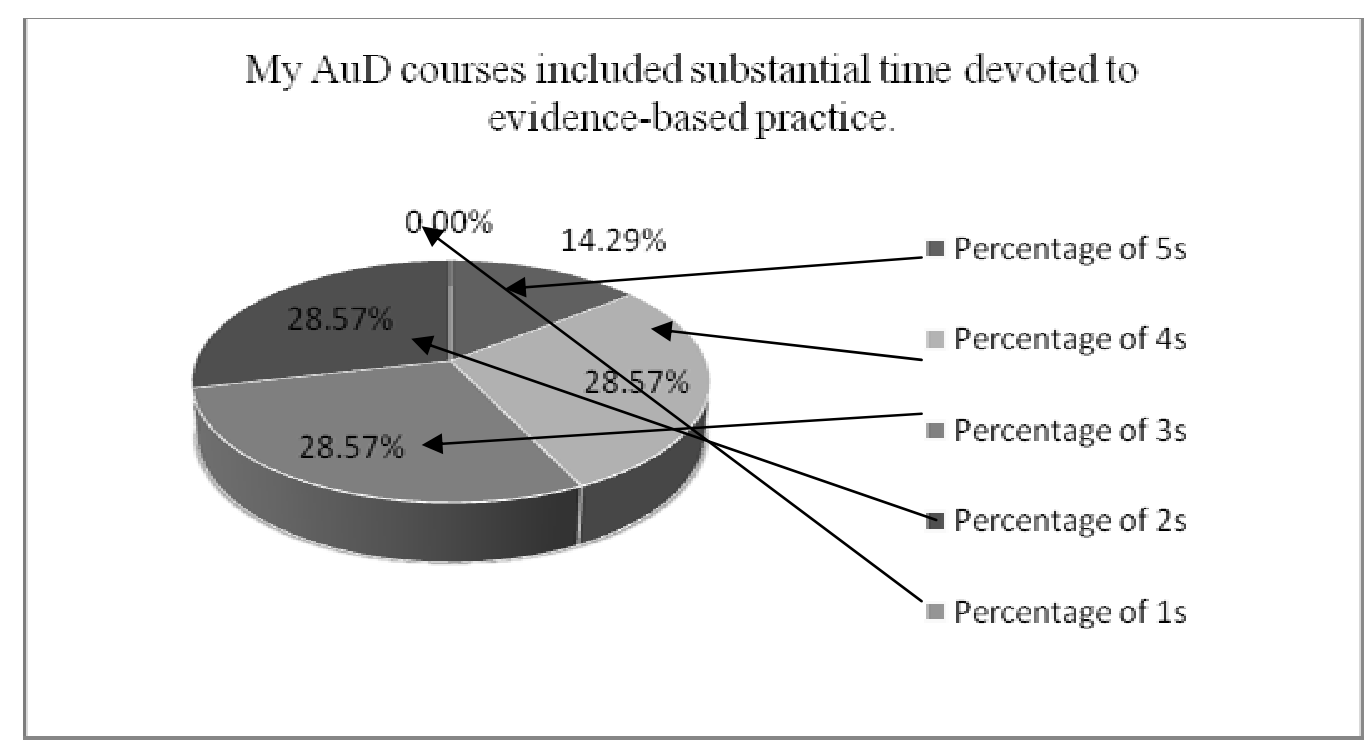

Responses were divided evenly among disagree (2s), neutral (3s) and agree (4s) to the statement that substantial time had been given to evidence-based practice in courses with $28.57 \%$ each. A smaller percentage strongly agreed with the statement. Based on previous discussions regarding interview categories and quotes, it is obvious that survey respondents did not have consistent opinions regarding the teaching of EBP in their AuD courses. 
Figure 13. I frequently read other AuD evidence posted.

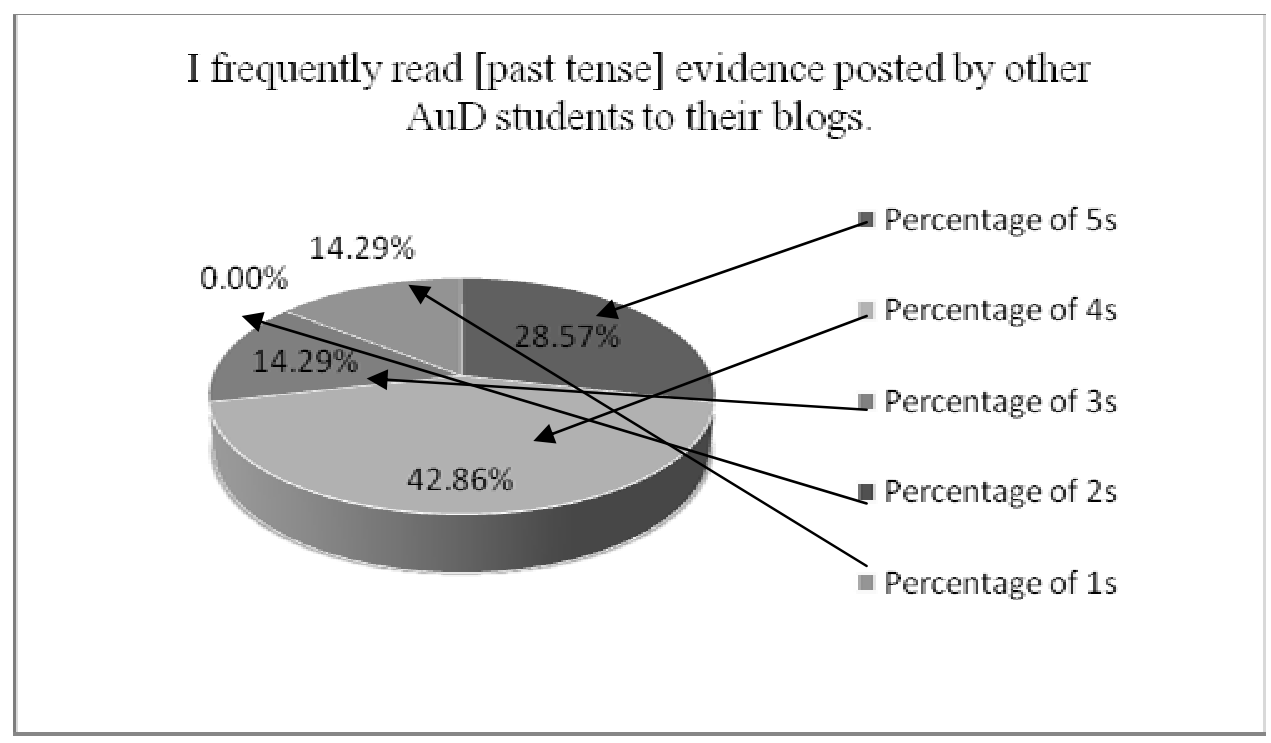

A small percentage of responses indicated strongly disagree (1s) or neutral (3s) to the item "I frequently read [past tense] evidence posted by other AuD students to their blogs" at 14.29\% each. More (42.86\%) agreed with the statement with scale rating of 4 and slightly less (28.75\%) strongly agreed that they read evidence posted by their peers, with a scale rating of 5 . When interviewees had been asked their favorite aspect of the Weblog assignment, the predominant category was that they liked reading peer blog posts.

Only one participant responded to the open-ended question. This response supports data from the interviews - "In regards to weblogs completed according to the requirements, some of the content read was beneficial when taking the Praxis examination (by completing the assignment and reading others)”.

Research questions 3 summary. Participants were asked what they had learned in their course about evidence-based practice. The majority of responses were regarding learning to read and understand research. Several responses indicated that some discussion of evidence occurred in their courses and a universal need for EBP in audiology was supported. Overall, participants 
indicated that, in retrospect, they had learned EBP principles in their course, however the phrase “evidence-based practice” had not been used.

Participants were asked if the blog assignment helped them learn about EBP. Three interviewees confirmed that they had not participated in the EBP component of the blog assignment and therefore could not answer. Of the remaining participants responses indicated that the blog assignment has helped learn about EBP and that in particular, the ability to consume research had improved as a result of the assignment.

Finally, I asked participants if there was anything else about evidence-based practice that they wanted to tell me. Responses to this question centered on the importance of evidence-based practice for a variety of reasons, and the importance of learning how to consume research. One response stated a positive aspect of the EBP Weblog assignment - "the blogs are a fun way to implement it.”

Summary of results. Analysis of the content of all Weblogs posted during this study period suggest that the students learned very little about evidence-based practice, in light of the low percentage (20\%) of blog posts that included a discussion of the evidence. However, interview data from students who had participated in the Weblog assignment indicated that students believed that they learned to find evidence to support clinical practices, could discuss evidence, and improved their abilities to consume research literature. Recommendations for modeling evidence-based practice and teaching students to read and understand research literature were made. These results also indicated that participants wanted more exposure to evidence-based practice throughout their graduate experience.

The majority of information arising from the Web-based survey support responses to interview questions. Survey responses indicate that the participants favor more exposure to 
evidence-based practice principles in both coursework and clinical practicum. This was also observed in interview responses. Perhaps the most interesting information found in the survey results is the remarkable affirmation that participants believed that they learned as a result of doing the Weblog assignment, although they did not necessarily like it as well.

Survey questions looking at exposure to evidence-based practice in the participants’ AuD courses helped to inform me of the knowledge and experience with EBP that the students had prior to beginning the Weblog assignment. This information would have been desirable before assigning Weblogs with an evidence-based practice component, because I could have prepared the students better for EBP principles in advance. This is one of the weaknesses of my study, which will be addressed in the discussion chapter. 


\section{CHAPTER 5}

\section{Discussion}

\section{Research Questions}

Research question 1. From the results of the interview question "What do AuD students learn about evidence-based practice from reading and writing clinic Weblogs?” participants indicated that they learned how to locate and discuss evidence related to cases they had encountered during their clinical practicum. However, analysis of blog content revealed limited discussion of evidence in the blog posts (20\%) and even fewer (18\%) source citations of evidence that had been uncovered. This is not consistent with Johnson's (2006) advice to communication disorder professionals to use a "show me the data" approach to clinic issues.

Participants defined EBP based not on the process to desired outcomes, but on the sources of evidence, which may reflect a basic misconception about the function of evidencebased practice. They appeared to have learned the importance of applying evidence for the benefit of their clients, which is consistent the purpose of EBP - excellent decision-making based on the best evidence available. In other words, audiologists should be using the best research to inform clinical practices.

Benefits from including EBP into the Weblog assignment included validation of clinical practices and improved patient care, which are consistent with the goals of evidence-based practice. Participants also described continued learning that occurred as a result of the Weblogs. Ruthman et al. (2004) found in their study that a clinic journaling assignment in nursing students contributed to an "interactive learning process.” AuD student participants responded that they liked to read their peers’ blogs because they believed they learned from their peers and that they 
felt they shared learning experiences. They indicated, both in interviews and in survey responses, that they learned from writing their own Weblog posts as well as from reading peer posts.

Several authors have identified barriers to evidence-based practice that impede its implementation. Fell and Burnham (2004) found that physical therapy students needed to be taught how to access and evaluate evidence for successful application. Limitations to writing the Weblog assignment with evidence-based practice in my study were selection of clinic cases to present, time limitations, and technology issues. While some of my participants had technology issues related to completing their Weblog posts, others had indicated that when they believed they had uncovered a source of specific evidence, often the source was not available without paying for the article - often not affordable on a graduate student's income.

While participants did not seem to experience barriers to reading peer blog posts, they certainly recognized those that lacked effort. Since the Weblog assignment was not graded during the study time period, there were no consequences associated with outstanding nor poor quality blog posts. One respondent expressed being irked at poor source selection from unidentified peer blog posts. In a study by Glogoff (2005), he noted that students who did not seem interested in the assigned topic refused participation in spite of it being a course requirement. And those who seemed interested, participated regularly.

Difficulty reading and understanding research was a common response given by my participants. In fact, it was a frequent response to questions probing what participants had learned about EBP in their courses, how the Weblog assignment helped them learn about EBP, and recommendations for teaching EBP in AuD programs. Yet they concluded that as a result of the Weblog assignment, their abilities to consume research had improved. 
Research question 2. Participants clearly had strong initial reactions to the Weblog assignment. My second research question was “What were AuD students’ reactions to writing and reading clinic Weblogs?” Overwhelmingly, the majority of participants stated that their initial reactions to the Weblog assignment was that they thought it was "busy work" - just one more thing that they had to do and did not see the value. They did respond that their opinions had changed to more positive over time, and stated that their favorite aspect of the assignment was reading blogs posted by their peers. Yet, when asked to identify specific clinical practices they found supported through the Weblogs, those who could discuss specific evidence did so from their own blog posts, not peer posts. This may be supported by Chabon and Lee-Wilkerson (2006), who studied the value of reflective journal practices from both courses and clinical experiences among students in a communication disorders course. They identified critical thinking skills in the journal entries, among other outcomes, and had summarized that using journal writing to assess student learning was promising.

When asked for recommendations to the blog assignment, participants asked for more demonstration of the Weblog task and for specific requirements. Similarly Bryant (2006) found that students need instruction in how to access and post to their blogs. Windham (2007) also found that students benefit from Weblog assignments when clear expectations have been given, blog posts were assessed in some manner, and instructors actively participated in the assignment. Although this data had not been collected at the time, following my study time period, I modified the Weblog assignment. This will be discussed later in this chapter.

While participants indicated that they learned as a result of the Weblog assignment, they liked the assignment less than they learned from it. This may be related to the studies by Bryant (2006) and Windham (2007) cited above. Martindale and Wiley (2005) had indicated that 
students became engaged in both the content and process of Weblog assignments when the assignments were carefully planned and managed. Modifications to the clinic Weblog assignment would be supported by these findings. These modifications will be discussed further.

Research question 3. Participants indicated that, in retrospect, they had learned about the importance of using evidence to support clinical practices from their AuD courses. They recognized that their professors had given them additional resources apart from the course textbooks and that everything that had been taught was based on evidence. But they stated they had not heard the phrase "evidence-based practice” until the Weblog assignment. Survey data supported interview data and indicated that more attention to principles of evidence-based practice was desired in both courses and clinical practicum.

In addition to those discussed above, other barriers to EBP found in the literature were inconsistencies in the ability to locate and consume research including limited computer skills, the need for consistency in making sense of research results, and limited access to empirical research in the light of time limitations (Thompson, et al., 2005). My study participants echoed this limitation. They commented that they initially did not know how to read and understand research articles. One participant recalled a time that she realized that she could make sense of a research article. In their recommendations to me regarding the EBP component of the Weblog assignment, they called for more help in consuming research literature as their primary recommendation.

Interview participants indicated that they would like to have seen EBP principles modeled and applied in more of their clinical practicum. Cope (2003) had stated that if EBP is to be applied successfully, all members of the team must be committed to its application. Mullen (2005) had also reported that insufficient time was a barrier to the adoption of EBP principles 
among speech-language pathologists and audiologists. My participants indicated that they want more exposure to application of evidence-based practice in their clinical practicum; and that in several instances, they have observed clinical evidence being ignored.

Participants reiterated the need for clearer guidelines and specific requirements regarding the Weblog assignment. They requested easy access to research such as copies of journal articles that are not due to lack of institutional subscriptions. And they suggested that, although clinical practicum sites may be applying EBP principles they would like to be involved in that process. Recommendations for Practice

The use of Weblogs to teach evidence-based practice for Doctor of Audiology students has been supported by my study. I would make recommendations for further implementation of the practice as well as to those who would consider using Weblogs to support EBP for AuD students.

My Weblog assignment evolved from reflective practice to including the evidence-based practice component. Prior to requiring students to discuss evidence-based practice, their familiarity with evidence-based practice principles should be assessed. Particularly in programs like ours where clinical faculty do not teach coursework in the AuD program, assumptions should not be made about what students know about EBP. Knowing the learners is foundational to instructional design. However, familiarity with the program as well as the students is not necessarily the same as knowing their instructional needs. Formal assessment of AuD students’ knowledge of EBP will be made prior to their clinical assignments.

Students should know what EBP is and what its purpose is. They should have instruction in the Levels of Evidence found in research studies, and a basic knowledge of research principles including study design, in order to determine the Level of Evidence a study provides. They must 
be taught to develop an answerable question before approaching the evidence. Use of the PICO mnemonic to create a question is recommended. Then they are ready to approach the evidence. I have already begun teaching EBP based on the ASHA 2004 Technical Report, including the determination of Levels of Evidence

Ideally, a repository of research articles relevant to the field of audiology should be available to $\mathrm{AuD}$ students from which they may locate and identify evidence supporting or refuting clinical practices. University libraries should maintain institutional electronic subscriptions to multiple audiology-related journals, including the American Journal of Audiology, the Journal of the American Academy of Audiology, Ear and Hearing, the Journal of the Acoustical Society of America, the International Journal of Audiology and Seminars in Hearing. Students should demonstrate the ability to conduct an electronic library search for relevant literature and to properly cite sources. I will be requesting full access of our libraries, and have begun compiling a collection of hard copy research articles in our in-house clinic.

In addition to being able to search, locate and cite research, students must be taught to be consumers of research literature. They may require directed analysis and discussion of study designs, results, and implications. The ability to analyze research findings and apply them to the clinical population is foundational to implementing evidence-based practice principles. While graduate students often take a course in basic research design, more attention should be given to making sense of research results. Incorporating EBP principles into clinical practicum will address this concern. Guided discussion of several research articles is recommended. The issue becomes when in the education of AuD students guided discussions should take place. In programs where a journal club is in place, this would be an appropriate activity. In programs where no journal club exists, considerations should be made regarding the development of some 
mechanism for discussion. Options might include developing a journal club, creating a regular “Grand Rounds” of clinical practicum, or creating a clinic course. Currently, a clinic course and a journal club exist in WVU's Master's program in Speech-Language Pathology but do not exist in our AuD program. I desire to plan and implement an Audiology Grand Rounds for AuD students enrolled in clinical practicum in our program.

A question arises about the use of evidence-based practice principles being implemented by current professionals, particularly those who are providing clinical practicum supervision at outside placements, as well as in-house placements. Professional licensure and certification requirements include a minimum prescribed number of approved continuing education hours. Like many professions, these requirements are aimed at keeping professional current in their clinical practices, and may include knowledge of current evidence.

For these professionals who are involved in the education of AuD students, evidencebased practice may be implemented without being obvious to students under their supervision. The emerging and existing evidence may be internalized and, combined with practitioner expertise and client preferences, excellent clinical decision-making may also not be obvious to students. This decision-making, and the related goal of providing high quality hearing healthcare to clients, can be seen to exist on an underlying foundation of clinical skills. Some practitioners may view an expanded clinical knowledge management pyramid to include skills and expertise. This may be visualized in the following figure. 
Figure 14. Clinical knowledge management pyramid.

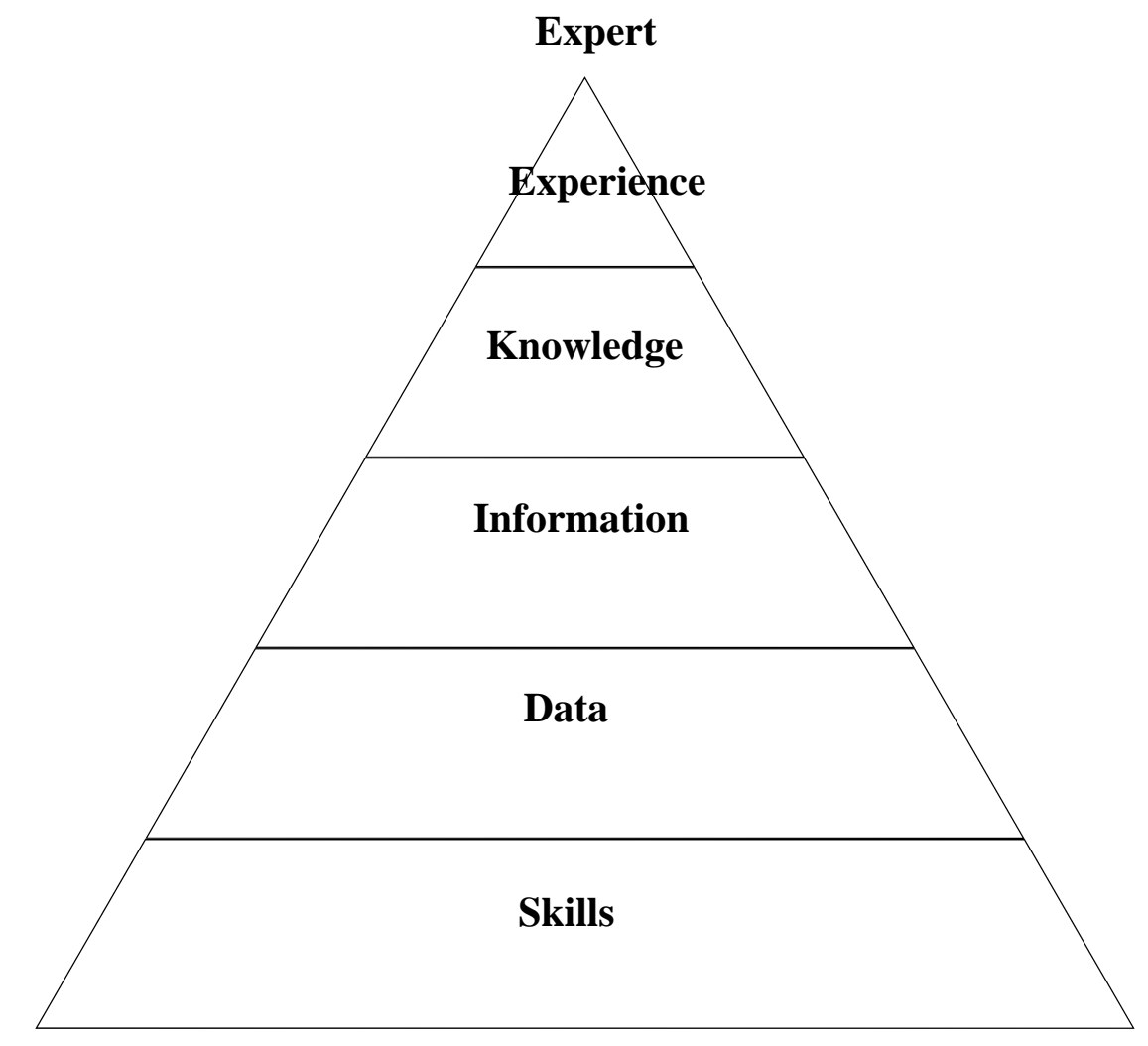

Students should be taught how to create, access, post, read, and comment on Weblogs.

Although I conducted an annual afternoon-long demonstration in a computer lab, my participants indicated that it was insufficient to prepare them for the assignment. Weblogs have become much more popular over the past few years, and younger learners may not require as much training and practice. However, assumptions should not be made. Ample time to experiment and practice with blogs should be given to students with little or no familiarity with the technology. My participants suggested a group blog with practice opportunities before the assignment formally began. I have since modified the blog assignment into group blogs based on the amount of clinical experience each group of AuD students have.

Faculty considering implementing Weblog assignments should carefully consider 
the general format of the blog. Should individual students have their own blogs? Or would a group blog better suit the goals of the assignment? What are the expectations of the learners? Are you interested in frequency of posts, content of posts, or both? How will you define the framework for content? How will you assess learner participation? Attention to these details can be expected to assay students’ concerns about what they are expected to do. My participants indicated that they had questions regarding expectations as well as frustration with peers who participated minimally.

The use of Weblogs to support evidence-based practice is recommended for use across the clinical component of our Doctor of Audiology program. Although graduate students do not begin their clinical practicum until their second year, they observe and complete audiograms along with the graduate clinician they observe. During the fourth year of the AuD program, students are placed full time in a residency site. They remain enrolled in the University until they have completed their residency year and all other requirements of the program. Adoption of the Weblog assignment across the four years of clinical activity is recommended, both as a means of sharing of clinical experiences and to continue to support evidence-based practice. Currently, these students are not under my clinical assignment.

This recommendation would extend to AuD programs nationally. Each program should evaluate the role of the activity in regards to its curriculum and the role of the assignment instructor should be defined.

If students' blog posts and comments can be considered as tangible records of their conversations, they may reveal areas where students feel more or less confident in their clinical skills. Although my analysis of KASA competencies did not reveal earned competencies of specific skills, exposure and experience in several competency areas were observed. An 
instructor participating in the Weblog assignment would have opportunity to address issues raised in these “conversations.” This might include providing clarification, specific advice or instruction, confirmation, or support. Although I have been an active participant in the previous Weblog assignment, I have acted as a facilitator. I intend to take a more active role in the assignment and will either address specific issues or will call for discussion of the issues..

As a result of this study, I have identified a set of recommendations to myself regarding improving my teaching in clinical practicum and in coordinating clinical practicum. Based on the paragraph above, an assessment of AuD students’ knowledge of evidence-based practice should be made. This assessment should occur annually, as new AuD students enter and progress through the program. A logical mechanism for this assessment is a simple survey including EBP principles and purpose as well as familiarity with Levels of Evidence. Reviewing this assessment will give me a basis for determination of what students need to learn about EBP before they can begin to think about applying the concepts for the Weblog assignment.

In addition to the initial computer lab session, where AuD students set up their blogs and practice posting, more practice will be given prior to commencing the EBP component of the assignment. I have considered that a single group blog may be more easily managed and may benefit AuD students by providing guided discussions and directing blog activities as they learn to access and communicate through the blog. This is an appropriate mechanism to begin teaching EBP principles. With a group blog format, the need for links to multiple student blogs is eliminated and students can more easily interact with their peers, in the forms of comments and new posts. If smaller group discussion is desired, student can be assigned to work in groups and separate posts can be created by these small groups. Yet all members of the blog can read and 
follow these posts. This contributes to the sharing of experiences and information that my participants indicated they liked.

A disconnect seems to exist between the call to incorporate evidence-based practice principles in clinical settings and the actual or consistent use of these principles. Participants in my study indicated that they had seen evidence ignored in outplacement settings and that when they asked about the specific practice, they were told “that's the way we do things here.” There is no doubt that barriers to using EBP principles exist, one of which is the factor of time in a busy environment. The reader is reminded of the statement by Dale (2006) that in order for EBP to be applied successfully, all members of the team must be committed to it. Although not addressed in this study, one might speculate that the use of EBP in medical professions may stimulate third party reimbursement systems to require healthcare professionals, including audiologists, to document the evidence used to support clinical practices prior to providing reimbursement. Third parties often require outcome measures before covering procedures or devices, so the jump to require evidence may not be unrealistic.

Finally, I have been convinced that requirements and assessment are needed in the Weblog assignment. Without a delineation of expectations, participation in the assignment was inconsistent among students. Without a plan and mechanism for assessment, participation could remain inconsistent. Windham (2007) recommended that clear expectations be provided, that blog posts be assessed in some manner, and that instructors maintain an active role in the blog assignment. An assessment plan I would recommend addresses content as well as frequency of blog posts. Content would be assessed for discussion of clinical evidence, contribution to and stimulation of further discussion, and apparent depth of thought observed in posts. Peer interactions among student bloggers were not investigated in my study, but in general 
interactions were supportive and positive. Again, peer support was not studied, but would be an area for future investigation.

Apparent depth of thought gives rise to larger questions about the profession of audiology. If evidence-based practice is purported to be data-driven, is the profession of audiology also data driven or is it driven by "pathways of practice”? Are audiology professionals practicing based on evidence or practicing based on a prescribed pathway of coursework that occurred at some time in the past? What traditional evaluation procedures do we cling to that evidence suggests might not be the best way evaluate hearing loss? Do our test procedures evaluate the communication problems that individuals with hearing loss experience? What does the data say about evaluation and treatment procedures? I am not proposing that we should scrap our methods of evaluating hearing and treating hearing loss, but rather suggest that we look to the evidence to determine which methods are effective for our individual clients. This requires critical evaluation of the research and calls for greater contributions to the body of research.

The debate among audiology professionals and our colleagues in related areas has persisted regarding the role of research in the professional Doctor of Audiology degree. Since the AuD degree has replaced the Master’s degree as the entry-level degree required for certification and employment for new professionals, many who view the degree strictly as the entry-level degree denounce the need for research skills for students. After all, these are the individuals who will be practicing audiology in hospitals, schools, ENT offices, and private practices where there is often little time nor need for research. Traditionalists who are bound to the concept that any doctoral-level program must, by nature, include a strong research component. While I cannot resolve this debate, it is clear to me from this study that if Doctor of Audiology professionals are to provide high quality hearing health care to their clients over a career span, the ability to read 
and make sense of research is critical, regardless if they contribute to the research base or not. AuD students need to be taught how to read research abstracts to determine if the full article has the potential to answer their question or need. They need to understand differences among study designs and which designs lend themselves to stronger levels of evidence. They need to be able to learn to identify the findings of research, evaluate the implications, and judge the appropriateness of the implications for their question or need. This needs to be taught early on in their graduate program, if not in their undergraduate career. Challenges therefore exist regarding effective ways of teaching AuD students to appropriately consume research. Are students afraid of research? How many AuD students nationally participate in research? If fears about research exist, do they impact the number of students contributing to research at the graduate school level? Is there a role for clinical research? When should students be first introduced to research articles? How can they best be taught to read and make sense of a research article? These are issues that need to be addressed.

How do we teach AuD students to consume research and contribute in return? How do we teach them to think about disruptions in the normal physiological processes of the auditory component of communication and which intervention(s) are appropriate for an individual? Do we teach them to find and use data to support clinical practices? Or do we provide instruction in the traditional pathways of practice - how things have always been done? Are we teaching our AuD students to think? Or are we training them to be technicians, as some of our critics have claimed? More pointedly, are healthcare professions including audiology driven by data, practice pathways, or reimbursement issues? If so, the proverbial cart would appear to be before the horse. 
If Doctor of Audiology programs are in fact seeking to educate professionals with a foundation of tools and methods and the ability to critically analyze the impact of existing and emerging research, these universities should be providing AuD students with full electronic access to all relevant publications. While universities must balance resources with demands, it seems obvious that providing students with easy access to the body of research that shapes and supports the profession should be a high priority.

Across the typical curriculum for a Doctor of Audiology program, data exists to support the majority of the coursework. I would propose that little in the profession is left to speculation or theory with the exception of complex physiological processes that cannot be observed directly, such as how auditory stimuli is processed in the brain or how the volley theory of cochlear stimulation occurs. This data provides the foundation for textbooks in the field. And as new textbooks are written and older texts are revised, emerging knowledge is included. The question arises regarding the rate of emerging data, information and knowledge and the responsiveness of textbook authors and publishers. Do AuD faculty find gaps between their current research consumption and the knowledge found in current textbooks?

\section{Weaknesses of the Study}

One of the weaknesses of my study is that I had not determined how much the students knew about EBP prior to beginning the Weblog assignment. Interview participants indicated that they would have liked more modeling, instruction, and even guided practice to complete the assignment properly. I would concur with their statements, and had amended the successive Weblog assignment prior to this study. I have since made a modification to the Weblog assignment that included an initial reading and discussion about evidence-based practice from the American Speech-Language-Hearing Association in the first Weblog assignment of the year, 
in a group blog. The blog discussions have been guided by several questions I pose and students are challenged to identify the Level of Evidence of each assigned reading, among other questions. A follow up study investigating what AuD students learn about EBP from reading and writing clinic Weblogs from the modified assignment is likely appropriate. It would be beneficial for me to know if I improve in teaching EBP, does AuD students’ learning about EBP improve.

Another EBP component missing from my Weblog assignment was the proper formulation of a clinical question. Using the PICO mnemonic device, student would be better prepared to formulate an answerable clinic question, and therefore locate and apply the best evidence available. This component should be included in future Weblog assignments, following appropriate instruction and demonstration.

A second modification has been made to the Weblog assignment since the conclusion of the study time period and prior to the data collection for my study. It was quite obvious to me, as well as my participants, that many blog posts lacked effort. Instead of empirical research being used to support clinic practices, commercial and opinion-based Websites were referenced in several blog posts. The absence of assessment of the assignment for both quality of discussion and appropriateness of evidence cited allowed weak or few blog posts. After an interim semester, I developed a rubric to evaluate three aspects of Weblog participation: concepts from readings, thoughtful reflection, and contribution to discussion.

Although weaknesses are present in my current study, it does shed light on learning that occurs as a result of including evidence-based practice principles into a clinic Weblog assignment. AuD students learned to critically assess their clinical practices, to locate clinical evidence, and to aim towards improved quality of clinical services to their patients/clients. Changes to the Weblog assignment and recommendations for further changes should be studied. 
Among variables that might be investigated are number of individual student Weblog posts or quality of posts based on some defined characteristic such as application to a case or level of evidence of evidence identified. Interestingly, responses to the Web-based survey indicated that participants believed that they learned as a result of the Weblog assignment. What they learned has been discussed qualitatively based on the blog analysis and interview analysis. Another area for future research is the quantification of what students learned from the Weblog assignment. However in an educational setting, focus should be on learning outcomes from Weblog assignments, evidence-based practice, or both.

\section{For Further Study}

Modifications I have made to my Weblog assignment since the end of my study timeline, such as group blogs, a blog discussion of an introduction to evidence-based practice article, and the development of a rubric for assessing blog participation, should be expected to improve learning outcomes of evidence-based practice in my AuD students. I would like to conduct a follow-up study on blog content existing since the end of my study timeline to be compared with the current data to determine any improvements in what AuD students learn about evidencebased practice using the Weblog assignment.

Another area for further study is to compare individual student participation in the Weblog assignment with their clinical competency ratings assigned by their clinical supervisors. This data exists for the pool of potential participants for my study and is a feasible study.

My analysis of all blog content indicated that only 20\% of the posts included some discussion of evidence. For most graduate level work, a proficiency of $80 \%$ is expected. While the occurrence of evidence discussion in a Weblog assignment may be difficult to directly compared to an $80 \%$ proficiency of coursework, I would have expected participants in an 
assignment including an investigation of evidence supporting or refuting a clinical practice to have discussed this evidence with a higher prevalence such as $50 \%$ or greater. The lack of assessment of the assignment may account for this low incidence. With the development of a rubric to assess student participation in the Weblog assignment, the prevalence of discussion of evidence can be compared to the current results, thereby providing some information regarding the value of assessing the assignment.

The field of healthcare informatics relies on medical data to inform the professions of medicine and nursing. Electronic medical records can be de-identified so that patient privacy can be maintained while data can be mined for meaning, information, and knowledge. The field of audiology has no such database. While good audiological research and recent meta-analyses of studies have yielded sources of evidence for the profession, we need more clinical research.

Finally, my participants’ complaints that they do not know how to consume research should be studied further to attempt to provide remediation early in a student's AuD program. Because these are the audiology practitioners of tomorrow, the ability to read and understand research may have the potential to increase the clinical research available to our profession in the future. The results can only be improved care for our clients. 


\section{References}

American Speech-Language-Hearing Association. (2004). Evidence-based practice in communication disorders: An introduction. [Technical Report]. Available from www.asha.org/policy.

American Speech-Language-Hearing Association. (2005). Evidence-based practice in communication disorders. [Position statement]. Available at http://www.asha.org/ members/deskref-journals/deskref/default

Beeson, P. (2005, August). Bringing blogs into the classroom: ‘New media’ platform gaining steam at universities. Quill Magazine, 27-29.

Bennet, S. \& Bennet, J. (2000). The process of evidence based practice in occupational therapy: Informing clinical decisions. Australian Occupational Therapy Journal, 47, 171-180.

Boud, D. (2001). Using journal writing to enhance reflective practice. New Directions Adult Continuing Education, 90, 9-17.

Bouldin, A. S., Holmes, E. R., \& Fortenberry, M. L., (2006). “Blogging” about course concepts: Using technology for reflective journaling in a communications class. American Journal of Pharmaceutical Education, 70(4), 1-8.

Brock, T. P., \& Smith, S. R. (2007). Instructional design and assessment: An interdisciplinary online course in health care informatics. American Journal of Pharmaceutical Education, 71(3), 1-5.

Bryant, T. (2006). Social software in academia. Educause Quarterly, 2, 61-64.

Cartwright, C. A., Korsen, N. \& Urbach, L. E. (2002). Teaching the teachers: Helping faculty in a family practice residency improve their informatics skills. Academic Medicine, 
77(5), 385-391.

Chabon, S. S. \& Lee-Wilkerson, D. (2006). Use of journal writing in the assessment of CSD students’ learning about diversity: A method worthy of reflection. Communication Disorders Quarterly, 27(3), 146-158.

Chisolm, T., Johnson, C. E., Danhauer, J. L., Portz, L. J., Abrams, H. B., Lesner, S., McCarthy, P. A., \& Newman, C. W. (2007). A systematic review of health-related quality of life and hearing aids: Final report of the American Academy of Audiology task force on the health-related quality of life benefits of amplification in adults. Journal of the American Academy of Audiology, 18, 151-183.

Cisero, C. (2006). Does reflective journal writing improve course performance? College Teaching, 54(2), 231-236.

Cope, D. (2003). Evidence-based practice: Making it happen in your clinical setting. Clinical Journal of Oncology Nursing, 7(1), 97-99.

Cox, R. M. (2005). Evidence-based practice in the provision of amplification. Journal of the American Academy of Audiology, 16, 419-438.

Dale, A.E. (2006). Determining guiding principles for evidence-based practice. Nursing Standard, 20(25), 41-46.

Descy, D. (2004). Let's put it in writing for everyone to see: The blog. TechTrends, 48(3), 4-5.

Downes, S. (2004, September/October). Educational blogging. Educause Review, 15-26.

Du, H. S. and Wagner, C. (2006). Weblog success: Exploring the role of technology. International Journal of Human-Computer Studies, 64, 789-798.

Fell, D. and J. Burnham (2004). Access is key: Teaching students and physical therapists to access evidence, expert opinion, and patient values for evidence-based practice. Journal 
of Physical Therapy Education, 18(3):13.

Flatley, M. E. (2005, March). Blogging for enhanced teaching and learning. Business Communication Quarterly, 77-80.

Forness, S. R. (2003). Barriers to evidence-based treatment: Developmental psychopathology and the niterdisciplinary disconnect in school mental health practice. Journal of School Psychology, 41(1), 61-67.

Georgiou, A., (2002). Data, information and knowledge: The health informatics model and its role in evidence-based medicine. Journal of Evaluation in Clinical Practice, 8(2), 127130.

Glogoff, S. (2005). Instructional blogging: Promoting interactivity, student-centered learning, and peer input. Retrieved June 31, 2007 from: http://www.innovateonline.info/ index.php?view=article\&id=126

Guyatt, G. H., Haynes, R. B., Jaeschke, R. Z., Cook, D. J., Green, L., Naylor, C. D., Wilson, M. C., \& Richardson, W. S. (2000). Users' guides to the medical literature XXV. Evidence-based medicine: Principles for applying the users’ guides to patient care. Journal of the American Medical Association, 284(10), 1290-1296.

Hernández-Ramos, P. (2004). Web logs and online discussions as tools to promote reflective practice. The Journal of Interactive Online Learning, 3(1), 1-16.

Johnson, C. (2006) Getting started in evidence-based practice for childhood speech-language disorders. American Journal of Speech-Language Pathology, 15, 20-35.

Johnson, J. M., Leung, G. M., Fielding, R., Tin, K. Y. K., \& Ho, L. (2003). The development and validation of a knowledge, attitude and behavior questionnaire to assess undergraduate evidence-based practice teaching and learning. Medical Education, 37, 
992-1000.

Kaye, B. K. (2005). It’s a blog, blog, blog, blog world. Atlantic Journal of Communication, 13(2), 73-95.

Kremenitzer, J. P. (2005). The emotionally intelligent early childhood educator: Self-reflective journaling. Early Childhood Education Journal, 33(1), 3-9.

Loavenbruck, A., Ricketts, T., Solodar, H., \& Sweetow, R. (2006). Guidelines for the audiologic management of adult hearing impairment. Retrieved July 27, 2007 from http://www.audiology.org/publications/documents/positions/Adultrehab.default.htm

Martindale, T. \& Wiley, D. E. (2005) Using weblogs in scholarship and teaching. TechTrends, 49(2), 55-61.

McIntyre, S. R. \& Tlusty, R. H. (1995, April). Computer-mediated discourse: Electronic dialogue journaling and reflective practice. Paper presented at the annual meeting of the American Educational Research Association, San Francisco, CA.

Melnyk, B. M. (2005, Third Quarter). “Advancing EBP in clinical and academic settings.” Worldviews on Evidence-Based Nursing. 2(3), 161-165.

Melnyk, B. M, \& Fineout-Overholt, E. (2002). Putting research into practice. Reflections on Nursing Leadership. 28(2), 22-25.

Mullen, R. (2005). Survey tests members’ understanding of evidence-based practice. ASHA Leader, Nov. 8, 4, 14.

Oravec, J.A. (2002). Bookmarking the world: Weblog applications in education. Journal of Adloescent \& Adult Literacy, 45(7), 616-621.

Pravikoff, D.S., Pierce, S.T., \& Tanner, A. (2005). Evidence-based practice readiness study supported by academy nursing informatics expert panel. In Melnyk, B. M. (2005, Third 
Quarter). “Advancing EBP in clinical and academic settings.” Worldviews on EvidenceBased Nursing. 2(3), 161-165.

Riley-Doucet, C. \& Wilson, S. (1997). A three-step method of self-reflection using reflective journal writing. Journal of Advanced Nursing, 25, 964-968.

Rosenberg, M.J. (2001). E-learning: strategies for delivering knowledge in the digital age. New York: McGraw Hill.

Russell, T. (2005). Can reflective practice be taught? Reflective Practice, 6(2), 199-204.

Ruthman, J., Jackson, J., Clusky, M., Flannigan, P., Folse, V. N., \& Bunten, J. (2004). Using clinical journaling to capture critical thinking across the curriculum. Nursing Education Perspectives, 25(3), 120-123.

Sackett, D.L., Rosenberg, W.M.C., Gray, J.A.M., Haynes, R.B., \& Richardson, W.S. (1996). Evidence-based medicine: What it is and what it isn't: It's about integrating individual Clinical expertise and the best external evidence. British Medical Journal, 312, 71-72.

Sackett, D.L., Straus, S.E., Richardson, W.S., Rosenberg, W., \& Haynes, R.B. (2000). Evidencebased medicine: How to practice and teach EBM. Edinburgh, United Kingdom: Churchill Livingstone.

Sleep, J., Page, S., \& Tamblin, L. (2002). Achieving clinical excellence through evidence-based practice: Report of an educational initiative. Journal of Nursing Management, 10, 139143.

Steward, B. (2001). Technological dreams: The implications of new technologies for occupational therapy education and evidence-based practice. Occupational Therapy International, 8(2), 145-150.

Stiler, G. M, \& Philleo, T. (2003) Blogging and blogspots: An alternative format for encouraging 
reflective practice among preservice teachers. Education, 123(4), 789-796.

Straus, S. E., Richardson, W. S., Glasziou, P., \& Haynes, R. B. (2005). Evidence-based medicine: How to practice and teach EBM. ( $3^{\text {rd }}$ ed.). Edinburgh, United Kingdom: Churchill Livingstone.

Thompson, C., D. McCaughan, D., Cullum, N., Sheldon, T., \& Raynor, P. (2005). Barriers to evidence-based practice in primary care nursing - why viewing decision-making as context is helpful. Journal of Advanced Nursing. 52(4), 432-444.

Trammel, K. D., Willliams, A. P., Postelnicu, M., \& Landreville, K. D. (2006). Evolution of online campaigning: Increasing interactivity in candidate websites and blogs through text and technical features. Mass Communication \& Society, 9(1), 21-44.

Walker, S.E. (2006). Journal writing as a teaching technique to promote reflection. Journal of Athletic Training. 41(2), 216-221.

Westbrook, J. I., Coiera, E. W., \& Gosling, A. S. (2005). Do online information retrieval systems help experienced clinicians answer clinical questions? Journal of the American Medical Informatics Association, 12(3), 315-321.

Windham, C. (2007). Reflecting, writing and responding: Reasons students blog. Educause Learning Initiative. Retrieved June 13, 2007, from http://www.educause.com.

Zeitz, K. \& McCutcheon, H. (2003). Evidence-based practice: To be or not to be, this is the question! International Journal of Nursing Practice, 9, 272-279. 


\section{Appendix A}

Knowledge and Skills Acquisition (KASA)

KASA form. The complete KASA form from the American Speech-Language-Hearing Association appears on the following pages. 

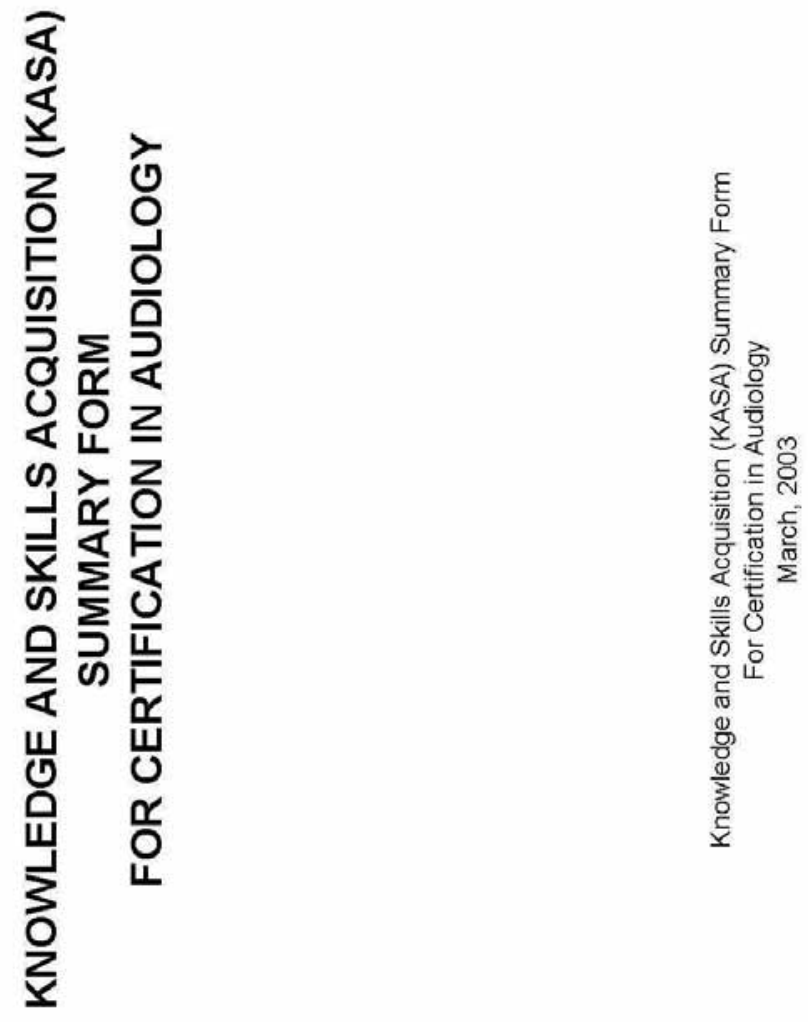


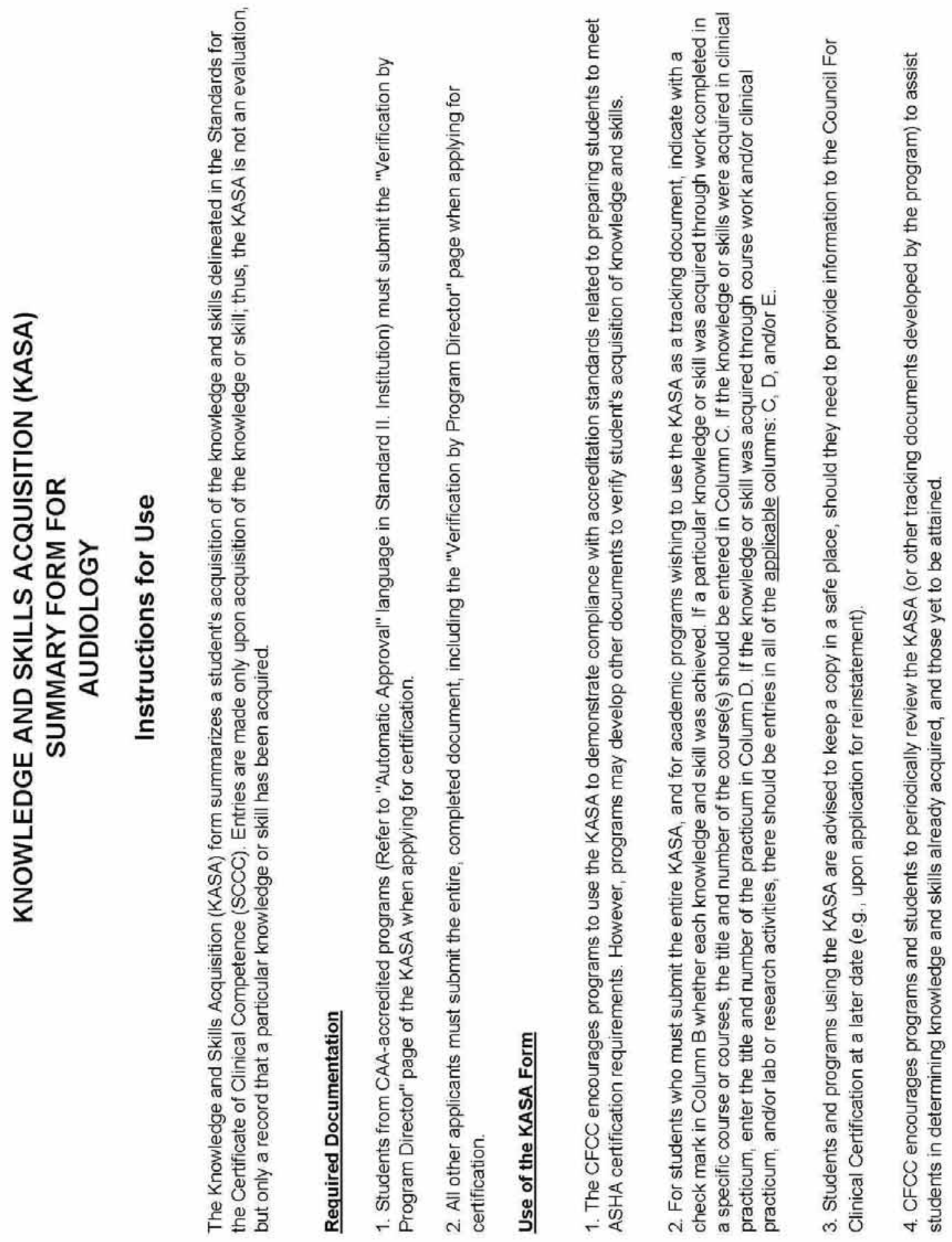




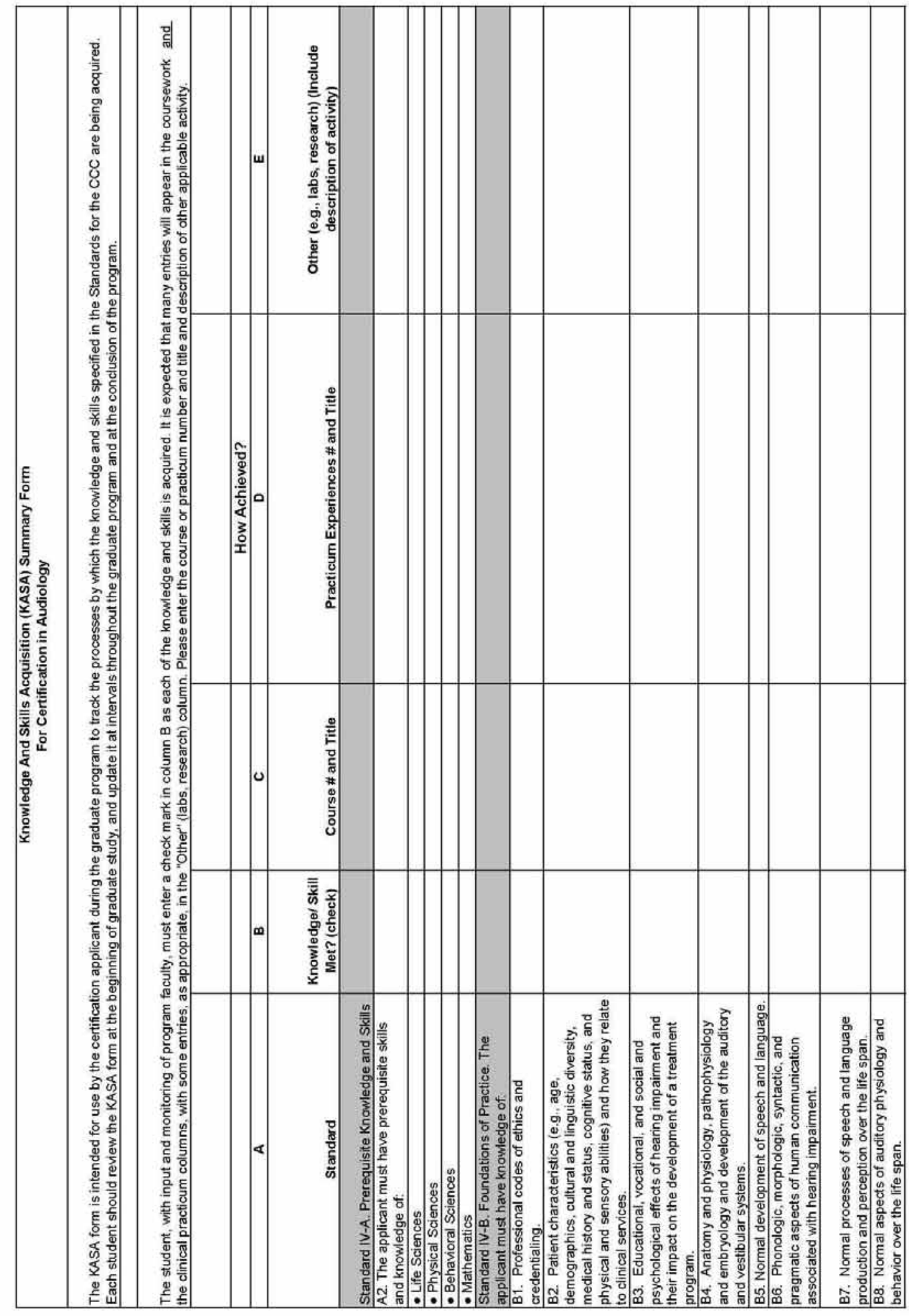




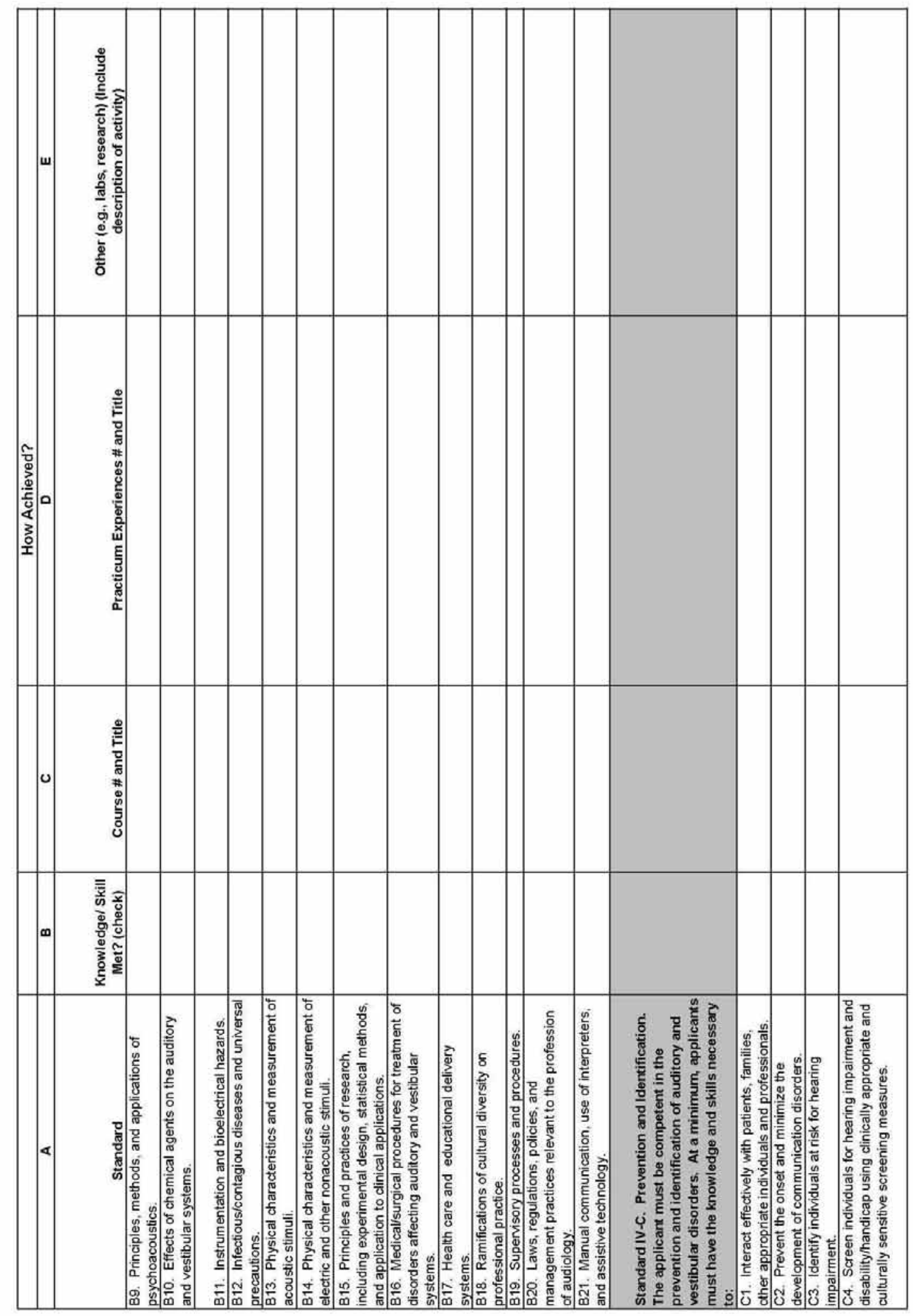




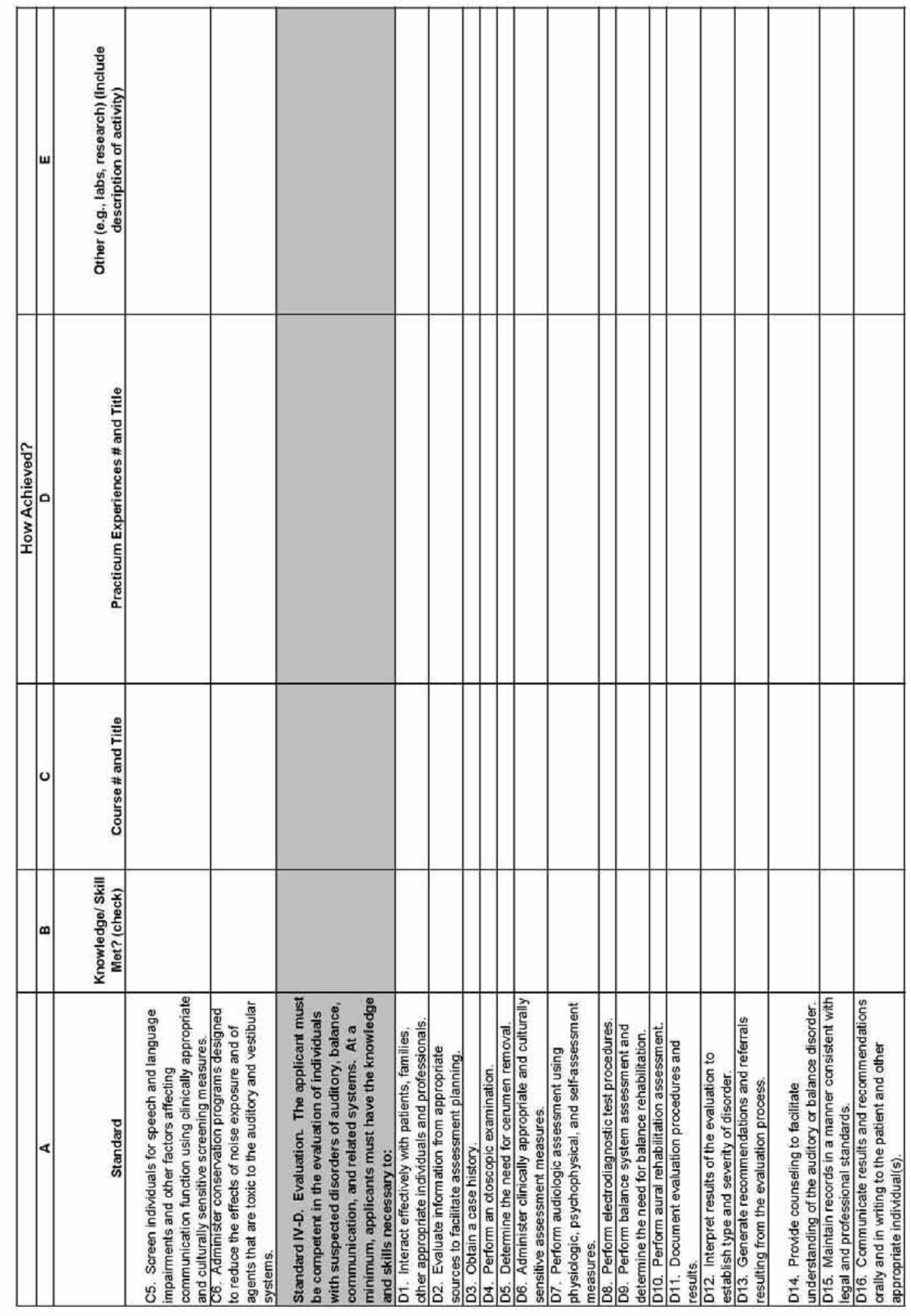




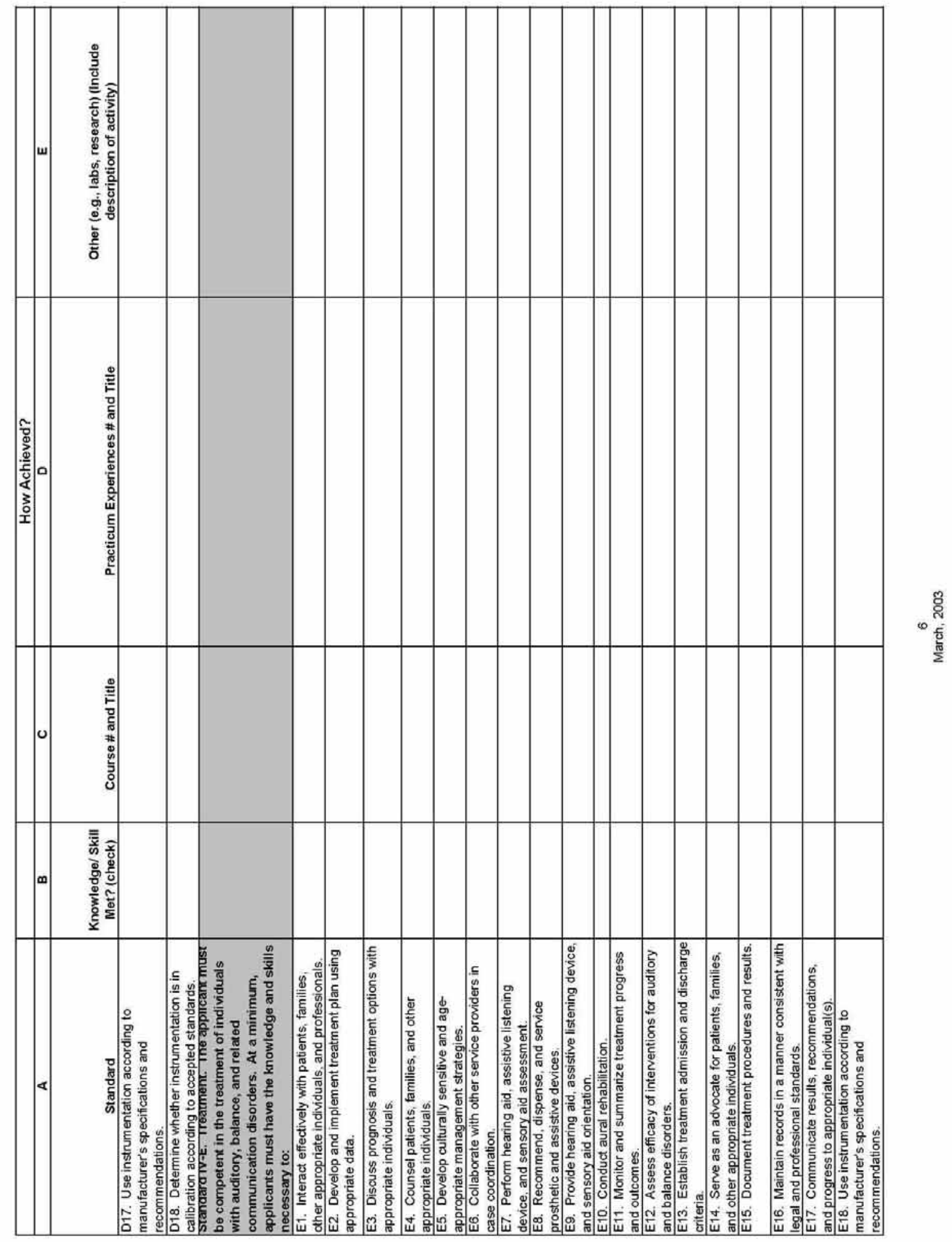


Electronic Clinic Journaling 107

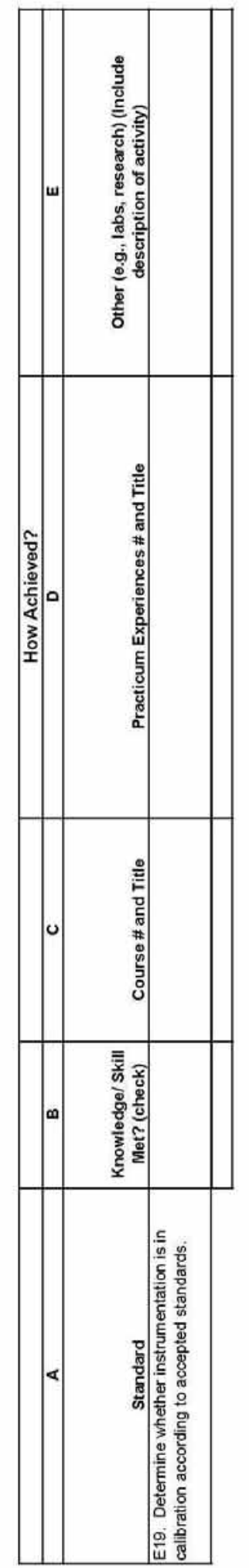




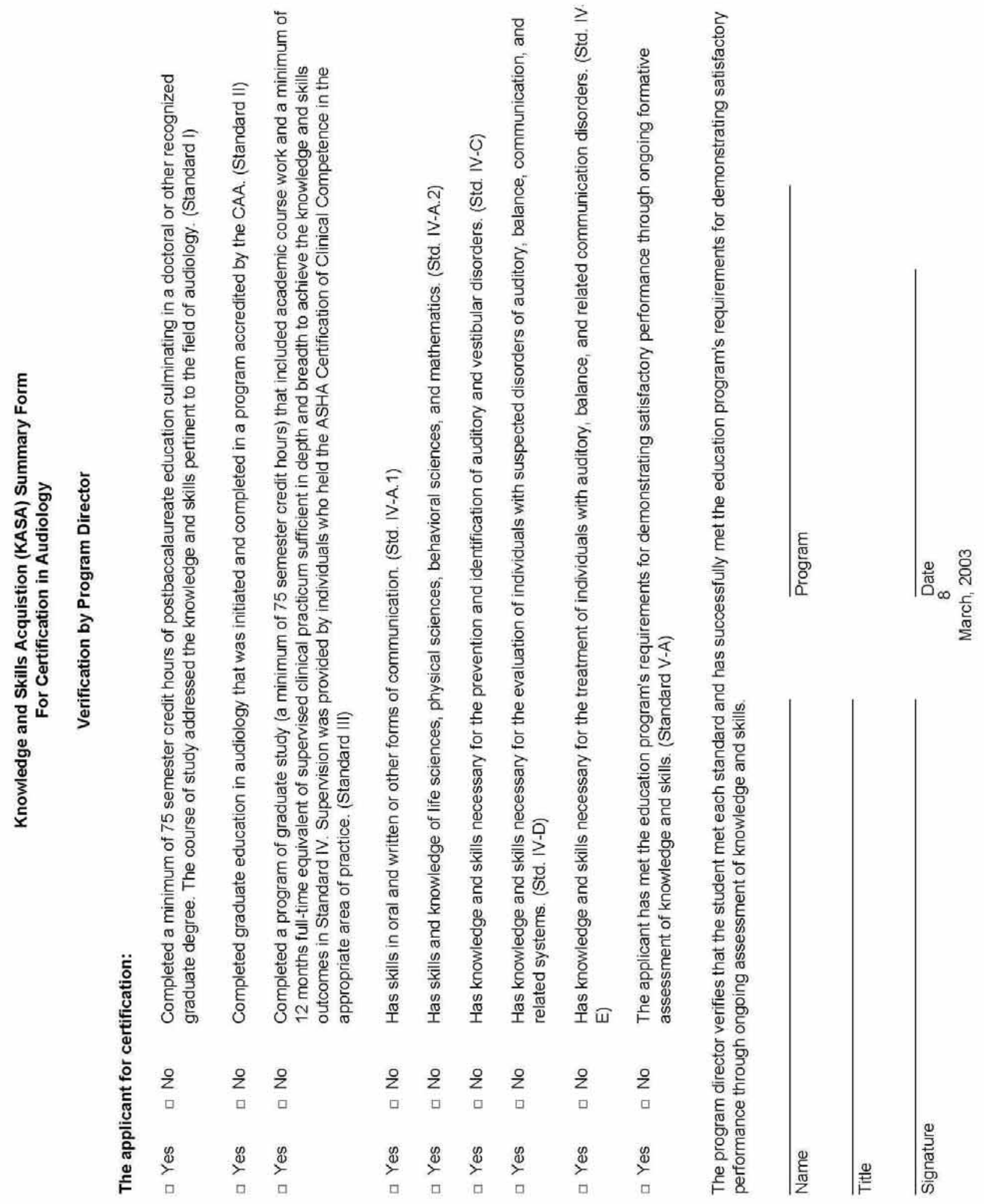




\section{Appendix B \\ Interview Questions}

Research question 1. The following list of questions will be posed to participants to help answer research question 1 - what do AuD students learn about evidence-based practice from writing and reading clinic Weblogs? Due to the nature of qualitative research, additional questions may arise during the interview process.

- How would you define the phrase "evidence-based practice”?

- How would you describe the purpose of “evidence-based practice”?

- Do you see any benefits from writing and reading Weblogs about clinic experiences? If so, describe them.

- Do you see any benefits from including evidence-based practice into the Weblogs? Explain this for me.

- What were the limitations or barriers you experienced with writing your Weblogs?

- What limitations or barriers did you experience reading other AuD students’ Weblogs?

- Can you identify any specific clinical practices that you learned or found supported from evidence you uncovered when writing your blogs? Explain those for me (if the answer was affirmative).

- Can you identify any specific clinical practices that you learned or found supported from evidence you read in another AuD student's blog?

Research question 2. The following list of questions will be posed to participants to help answer research question 2 - what are AuD students’ reactions to writing and reading clinic Weblogs?

- Tell me what your initial reactions to the Weblog assignment were. 
- Did your opinion of the assignment change over time?

- What was your favorite aspect of the blog assignment?

- What was your least favorite aspect of the blog assignment?

- What recommendations would you make regarding the blog assignment?

- Is there anything else about the blog assignment that you want to tell me?

Research question 3. The following list of questions will be posed to participants to help answer research question - what are AuD students' reactions to evidence-based practice?

- What have you learned in your courses about evidence-based practice?

- Does the blog assignment help you learn about evidence-based practice? How? (if appropriate).

- Have you read any journal articles or textbook information about evidence-based practice? Tell me about what you've read (if affirmative).

- Have you saved any specific evidence that you think you may use in the future?

- Have you thought about how you will implement evidence-based practice when you begin working as an audiologist? (Discuss this further based on the answer)

- How do you think evidence-based practice should be taught in AuD programs?

- What recommendations would you have for our AuD program, regarding teaching evidence-based practice?

- What recommendations would you make with regards to the evidence-based practice component of the Weblog assignment?

- Does more need to be done in your graduate courses to expose you to evidence-based practice? 
- Does more need to be done in your clinical practicum to expose you to evidence-based practice?

- Is there anything else about evidence-based practice that you want to tell me? 


\section{Appendix C}

Survey Items

Likert-type response items. The following list of statements will be used to create the Web-based anonymous survey that will be presented to the participants. These items will replicate interview questions in an attempt to confirm or confound the interview responses. Responses to these survey items will help to answer both research question 2 (what are AuD students' reactions to writing and reading clinic Weblogs?) and research question 3 (what are AuD students’ reactions to evidence-based practice?). Each statement will have five option responses on a Likert-type scale, with 1 being the strongest negative response and 5 being the strongest positive response (i.e., 1 = strongly disagree; 2 = disagree; 3 = neutral; 4 = agree; and 5 = strongly agree).

- $\quad$ I liked the Weblog assignment.

- I learned from Weblog assignment.

- I frequently read evidence posted by other AuD students to their blogs.

- My AuD courses included substantial time devoted to evidence-based practice.

- I learned very little about evidence-based practice in my AuD courses.

- My clinical practicum included substantial time devoted to evidence-based practice.

- I learned a great deal about evidence-based practice in my clinical practicum.

- More needs to be done in my graduate courses to expose me to evidence-based practice.

- More needs to be done in my clinical practicum to expose me to evidence-based practice. 
Open-ended question. Participants will be offered a final open-ended question in which the participants may enter any additional comments about the Weblog assignment and/or the evidence-based practice component.

- Please make any comments about the Weblog assignment and/or the evidence-based practice component that you would like to include. 


\section{Appendix D}

Tabular Results of Research Question 1 Data

Table 30.

RQ1: All Blog Data EBP Categories and Frequency Counts.

\begin{tabular}{|l|l|}
\hline \multicolumn{1}{|c|}{ Categories } & \multicolumn{1}{c|}{ Frequency Counts } \\
\hline Discussion of evidence & 80 \\
\hline Reference citation of evidence cited & 73 \\
\hline Web links to evidence referenced provided & 64 (of the 73 citations above) \\
\hline Evidence findings reported & 40 \\
\hline Clinical recommendations reported from evidence & 40 \\
\hline Internet articles used as evidence & 40 \\
\hline Websites used as evidence & 29 (of the 40 Internet articles \\
& above) \\
\hline Vague report of evidence with no citations or sources & 12 \\
\hline Treatment recommendations reported from evidence & 4 \\
\hline
\end{tabular}

Table 31.

RQ1. Quotes From Blog Content EBP Categories.

\begin{tabular}{|c|c|}
\hline Categories & Quotes from Weblogs \\
\hline \multirow[t]{4}{*}{ Discussion of evidence } & $\begin{array}{l}\text { "The article discusses the conditions and implications for } \\
\text { audiologic management," }\end{array}$ \\
\hline & $\begin{array}{l}\text { as “this definitely explains why 'ice cream' came out as ‘i } \\
\text { eam.”” }\end{array}$ \\
\hline & $\begin{array}{l}\text { "Although, it mainly focuses on the pediatric population it } \\
\text { provides a lot of useful information,” }\end{array}$ \\
\hline & $\begin{array}{l}\text { "I decided to discuss a little about the effects hearing } \\
\text { impairments have on cognition" }\end{array}$ \\
\hline \multirow{3}{*}{$\begin{array}{l}\text { Reference citation of } \\
\text { evidence cited }\end{array}$} & “According to Desmond (2004),” \\
\hline & $\begin{array}{l}\text { "Intertest Variability and the Air-Bone Gap" (1967) Journal of } \\
\text { Speech \& Hearing Disorders, 32, 82-86,” }\end{array}$ \\
\hline & “(Moffat, 1989).” \\
\hline Web links to evidence & "http://tap.gallaudet.edu/DigWirelessLKS/DigWireless.htm” \\
\hline
\end{tabular}




\begin{tabular}{|c|c|}
\hline \multirow[t]{4}{*}{ provided } & $\begin{array}{l}\text { "http://psychsoc.gerontologyjournals.org/cgi/content/ } \\
\text { full/59/3/S190!!” }\end{array}$ \\
\hline & "http://www.fcc.gov/cgb/consumerfacts/hac.html” \\
\hline & $\begin{array}{l}\text { "http://www.asha.org/NR/rdonlyres/8404EA5B-8710-4636- } \\
\text { B8C4-8A292E0761E0/0/v2TR_CAPD.pdf” }\end{array}$ \\
\hline & $\begin{array}{l}\text { "http://www.audiologyonline.com/articles/ } \\
\text { article_detail.asp?article_id=345.” }\end{array}$ \\
\hline \multirow[t]{5}{*}{ Evidence findings reported } & $\begin{array}{l}\text { "Interestingly enough, this week (the } 16 \text { th) Tier } 1 \text { providers are } \\
\text { going to be REQUIRED to manufacture at least five ANSI U3T } \\
\text { or M3T rated digital wireless handsets by the Hearing Aid } \\
\text { Compatibility for Telephone Equipment requirement under the } \\
\text { Hearing Aid Compatibility Act of 1988." }\end{array}$ \\
\hline & $\begin{array}{l}\text { "In the Guidelines for the Audiologic Management of Adult } \\
\text { Hearing Impairment prepared by the American Academy of } \\
\text { Audiology Task Force for Guidelines for the Audiologic } \\
\text { Management of Adult Hearing Impairment, it was stated that } \\
\text { "while approximately } 17 \text { in } 1,000 \text { children under age } 18 \text { have } \\
\text { hearing loss, the incidence increases with age so that } \\
\text { approximately } 314 \text { in 1,000 people over age } 65 \text { have hearing } \\
\text { loss."” }\end{array}$ \\
\hline & $\begin{array}{l}\text { "DPOAE emissions were consistently lower in amplitude in } \\
\text { affected ears of Meniere's patients compared to non affected } \\
\text { people with the same hearing." }\end{array}$ \\
\hline & $\begin{array}{l}\text { “the incidence of Meniere's disease in childhood has been } \\
\text { reported to range between } 1 \% \text { and } 7 \% \text { of all patients diagnosed } \\
\text { with the disease”. }\end{array}$ \\
\hline & $\begin{array}{l}\text { "She suggests that adults with high frequency hearing loss } \\
\text { experience changes in the brain from lack of acoustic } \\
\text { stimulation in those frequencies that impacts word recognition } \\
\text { scores." }\end{array}$ \\
\hline \multirow[t]{2}{*}{$\begin{array}{l}\text { Clinical recommendations } \\
\text { reported from evidence }\end{array}$} & $\begin{array}{l}\text { "AAA strongly encourages the careful monitoring of children } 6 \\
\text { months and under as well as any high risk disorder group (such } \\
\text { as Down syndrome). In addition to the standard battery we use } \\
\text { (air, bone, tymps, and speech) counseling parents is } \\
\text { emphasized" }\end{array}$ \\
\hline & $\begin{array}{l}\text { "Audiologists are often the first professionals to encounter } \\
\text { parents of children presenting with a variety of problems. These } \\
\text { problems may sometimes be a result of genetic disorders. It is } \\
\text { very important for audiologists to be aware of "genetic red } \\
\text { flags", and this may be done by obtaining an in depth family } \\
\text { history.” }\end{array}$ \\
\hline
\end{tabular}




\begin{tabular}{|c|c|}
\hline & $\begin{array}{l}\text { "If this occurs, then appropriate interventions could prevent } \\
\text { permanent hearing loss... of course this all depends on the } \\
\text { reliability, accuracy and validity of the particular OAE being } \\
\text { used It is recommended that ASHA develops a standardization } \\
\text { in ways to obtain both UCL and MCL because of the wide } \\
\text { variability." }\end{array}$ \\
\hline & $\begin{array}{l}\text { "One last key point that the article suggests is patience. If you } \\
\text { can't get accurate results with one test remain calm and move on } \\
\text { to something else within your battery." }\end{array}$ \\
\hline & $\begin{array}{l}\text { "Be aware and knowledgeable of the effect of multilingualism } \\
\text { on audiology practice." }\end{array}$ \\
\hline \multirow[t]{3}{*}{$\begin{array}{l}\text { Internet articles used as } \\
\text { evidence }\end{array}$} & $\begin{array}{l}\text { "According to an article from the Baylor College of Medicine } \\
\text { website" }\end{array}$ \\
\hline & $\begin{array}{l}\text { "According to the article: The Association between } \\
\text { Cardiovascular Disease and Cochlear function in older adults by } \\
\text { Torre et al" }\end{array}$ \\
\hline & $\begin{array}{l}\text { "Deafness and other Communicative Disorders (NIDCD)'s } \\
\text { website provides a lot of good information on both children and } \\
\text { adults with auditory processing disorders.” }\end{array}$ \\
\hline \multirow[t]{3}{*}{ Websites used as evidence } & "according to the Health A to Z website" \\
\hline & "found a hearing aid museum website" \\
\hline & "According to Ultimate Ears," \\
\hline \multirow[t]{2}{*}{$\begin{array}{l}\text { Vague report of evidence } \\
\text { with no citations or sources }\end{array}$} & $\begin{array}{l}\text { "great article on EBSCOHost through the WVU libraries } \\
\text { website" }\end{array}$ \\
\hline & $\begin{array}{l}\text { "hearing aid users ask questions and another Ph.D. and hearing } \\
\text { aid user answers them. It's not a research based website; } \\
\text { however, it is extremely helpful to users and audiologists may } \\
\text { be able to get a couple of tips." }\end{array}$ \\
\hline \multirow[t]{3}{*}{$\begin{array}{l}\text { Treatment recommendations } \\
\text { reported from evidence }\end{array}$} & $\begin{array}{l}\text { "If medication is not able to save the hearing of a person with } \\
\text { autoimmune inner ear disease, a cochlear implant can be used." }\end{array}$ \\
\hline & $\begin{array}{l}\text { "It is also helpful to belong to a group for children and teens } \\
\text { with autism and language disorders who exhibit difficulty with } \\
\text { peer relationships. Group activities teach strategies for } \\
\text { successful social interactons." }\end{array}$ \\
\hline & $\begin{array}{l}\text { "treatment is started early. Corticosteroid medications such as } \\
\text { prednisone are most commonly used" }\end{array}$ \\
\hline
\end{tabular}


Table 32.

RQ1: General KASA Skills Standards Categories and Corresponding Frequency Counts

\begin{tabular}{|l|l|}
\hline \multicolumn{1}{|c|}{ General KASA Skills Categories } & Frequency Counts \\
\hline KASA Evaluation & 273 \\
\hline KASA Evaluation Results & 230 \\
\hline KASA Treatment - Hearing Aids & 220 \\
\hline KASA Treatment Assessment & 59 \\
\hline KASA Pediatric Modification & 55 \\
\hline KASA Hearing Conservation & 52 \\
\hline KASA Evaluation - Vestibular & 48 \\
\hline KASA Treatment & 42 \\
\hline Amplification Recommended & \\
\hline Earmold Impressions & 37 \\
\hline Counsel Results & 34 \\
\hline KASA otoscopy & 32 \\
\hline KASA Evaluation - Auditory Processing Disorders & 31 \\
\hline KASA Evaluation - Hearing Screening & 31 \\
\hline KASA Evaluation - Otoacoustic Emissions & 29 \\
\hline KASA Referral to ENT Physician & 28 \\
\hline KASA Modification for Difficult to Test & 28 \\
\hline KASA Treatment - Cochlear Implants & 27 \\
\hline KASA Treatment - Hearing Aid Verification & 20 \\
\hline KASA Evaluation - Auditory Brainstem Response & 18 \\
\hline KASA Cerumen & 17 \\
\hline KASA General Treatment Outcomes & 17 \\
\hline KASA General Referrals & 11 \\
\hline KASA Treatment - FM systems & 11 \\
\hline KASA Treatment - Aural Rehabilitation & 10 \\
\hline KASA Prevention & 10 \\
\hline KASA Collaboration & 9 \\
\hline KASA Referral for Further Audiological Testing & 9 \\
\hline & \\
\hline
\end{tabular}




\begin{tabular}{|l|l|}
\hline KASA Treatment - Cerumen & 8 \\
\hline KASA Referral to Unspecified MD & 6 \\
\hline KASA Evaluation - Electrocochleography & 5 \\
\hline KASA Treatment - Vestibular & 5 \\
\hline KASA Referral to Speech-Language Pathologist & 5 \\
\hline KASA Evaluation - ENoG & 5 \\
\hline KASA Treatment - Assistive Listening Devices & 3 \\
\hline KASA Infection Control & 2 \\
\hline KASA IEP Collaboration & 2 \\
\hline KASA Referral to Other Professional & 2 \\
\hline KASA Treatment - Cochlear Implant (Bimodal) & 2 \\
\hline KASA Evaluation - Instructions to Patients & 1 \\
\hline KASA Treatment - Tinnitus & 1 \\
\hline
\end{tabular}

Table 33 displays the same frequency count information in the standard KASA format, in order of appearance on the KASA form. Empty frequency count cells indicate that no codes were marked for the standard.

Table 33.

RQ1: Standard KASA Skills and Frequency Counts

\begin{tabular}{|l|l|}
\hline \multicolumn{1}{|c|}{ KASA Skills Standards } & \multicolumn{1}{|c|}{ Frequency Counts } \\
\hline Standard IV-C. Prevention and Identification. & 10 \\
\hline $\begin{array}{l}\text { C1. Interact effectively with patients, families, other appropriate } \\
\text { individuals and professionals }\end{array}$ & 31 \\
\hline $\begin{array}{l}\text { C2. Prevent the onset and minimize the development of } \\
\text { communication disorders. }\end{array}$ & \\
\hline C3. Identify individuals at risk for hearing impairment. & \\
\hline $\begin{array}{l}\text { C4. Screen individuals for hearing impairment and } \\
\text { disability/handicap using clinically appropriate and culturally } \\
\text { sensitive screening measures. }\end{array}$ & $\begin{array}{l}\text { C5. Screen individuals for speech and language impairments and } \\
\text { other factors affecting communication function using clinically }\end{array}$ \\
\hline
\end{tabular}




\begin{tabular}{|c|c|}
\hline \multicolumn{2}{|l|}{ appropriate and culturally sensitive screening measures. } \\
\hline $\begin{array}{l}\text { C6. Administer conservation programs designed to reduce the } \\
\text { effects of noise exposure and of agents that are toxic to the } \\
\text { auditory and vestibular systems. }\end{array}$ & 52 \\
\hline \multicolumn{2}{|l|}{ Standard IV-D. Evaluation } \\
\hline $\begin{array}{l}\text { D1.Interact effectively with patients, families, other appropriate } \\
\text { individuals and professionals. }\end{array}$ & 1 \\
\hline \multicolumn{2}{|l|}{$\begin{array}{l}\text { D2. Evaluate information from appropriate sources to facilitate } \\
\text { assessment planning. }\end{array}$} \\
\hline \multicolumn{2}{|l|}{ D3. Obtain a case history. } \\
\hline D4. Perform an otoscopic examination. & 32 \\
\hline D5. Determine the need for cerumen removal. & 25 \\
\hline $\begin{array}{l}\text { D6. Administer clinically appropriate and culturally sensitive } \\
\text { assessment measures. }\end{array}$ & $\begin{array}{l}\text { Pediatric modifications }-55 \\
\text { Modifications: Difficult to } \\
\text { test }-28\end{array}$ \\
\hline $\begin{array}{l}\text { D7. Perform audiologic assessment using physiologic, } \\
\text { psychophysical, and self-assessment measures. }\end{array}$ & $\begin{array}{l}\text { Hearing evaluation - } 273 \\
\text { Auditory Processing } \\
\text { Disorders - } 31 \\
\text { Otoacoustic Emissions - } 29\end{array}$ \\
\hline D8. Perform electrodiagnostic test procedures. & $\begin{array}{l}\text { Auditory Brainstem } \\
\text { Response - } 18 \\
\text { Electrocochleography }-5 \\
\text { Electroneuronograpy - } 5\end{array}$ \\
\hline $\begin{array}{l}\text { D9. Perform balance system assessment and determine the need } \\
\text { for balance rehabilitation. }\end{array}$ & 48 \\
\hline \multicolumn{2}{|l|}{ D10. Perform aural rehabilitation assessment. } \\
\hline \multicolumn{2}{|l|}{ D11. Document evaluation procedures and results. } \\
\hline $\begin{array}{l}\text { D12. Interpret results of the evaluation to establish type and } \\
\text { severity of disorder. }\end{array}$ & 230 \\
\hline $\begin{array}{l}\text { D13. Generate recommendations and referrals resulting from the } \\
\text { evaluation process. }\end{array}$ & $\begin{array}{l}\text { Referral to ENT Physician - } \\
28 \\
\text { Unspecified referrals - } 11 \\
\text { Referral for further } \\
\text { audiological testing - } 9 \\
\text { Referral to unspecified } \\
\text { Physician - } 6 \text { Referral to } \\
\text { SLP - } 5 \\
\text { Referral to other } \\
\text { professional - } 2\end{array}$ \\
\hline
\end{tabular}




\begin{tabular}{|c|c|}
\hline $\begin{array}{l}\text { D14. Provide counseling to facilitate understanding of the } \\
\text { auditory or balance disorder. }\end{array}$ & 34 \\
\hline \multicolumn{2}{|l|}{$\begin{array}{l}\text { D15. Maintain records in a manner consistent with legal and } \\
\text { professional standards. }\end{array}$} \\
\hline \multicolumn{2}{|l|}{$\begin{array}{l}\text { D16. Communicate results and recommendations orally and in } \\
\text { writing to the patient and other appropriate individuals. }\end{array}$} \\
\hline $\begin{array}{l}\text { D17. Use instrumentation according to manufacturers' } \\
\text { specifications and recommendations. }\end{array}$ & Infection control - 2 \\
\hline \multicolumn{2}{|l|}{$\begin{array}{l}\text { D18. Determine whether instrumentation is in calibration } \\
\text { according to accepted standards. }\end{array}$} \\
\hline \multicolumn{2}{|l|}{ Standard IV-E. Treatment } \\
\hline \multicolumn{2}{|l|}{$\begin{array}{l}\text { E1. Interact effectively with patients, families, other appropriate } \\
\text { individuals and professionals. }\end{array}$} \\
\hline $\begin{array}{l}\text { E2. Develop and implement treatment plan using appropriate } \\
\text { data. }\end{array}$ & $\begin{array}{l}\text { Vestibular }-5 \\
\text { Tinnitus }-1\end{array}$ \\
\hline \multicolumn{2}{|l|}{$\begin{array}{l}\text { E3. Discuss prognosis and treatment options with appropriate } \\
\text { individuals. }\end{array}$} \\
\hline \multicolumn{2}{|l|}{ E4. Counsel patients, families, and other appropriate individuals. } \\
\hline \multicolumn{2}{|l|}{$\begin{array}{l}\text { E5. Develop culturally sensitive and age-appropriate management } \\
\text { strategies. }\end{array}$} \\
\hline E6. Collaborate with other service providers in case coordination. & 11 \\
\hline $\begin{array}{l}\text { E7. Perform hearing aid, assistive listening device, and sensory } \\
\text { aid assessment. }\end{array}$ & $\begin{array}{l}\text { Hearing aids }-59 \\
\text { Assistive Listening Devices } \\
-3 \\
\text { Cochlear Implants - } 29\end{array}$ \\
\hline $\begin{array}{l}\text { E8. Recommend, dispense, and service prosthetic and assistive } \\
\text { devices. }\end{array}$ & $\begin{array}{l}\text { Hearing aid } \\
\text { fittings/orientation - } 53 \\
\text { Earmold impressions - } 37\end{array}$ \\
\hline $\begin{array}{l}\text { E9. Provide hearing aid, assistive listening device, and sensory } \\
\text { aid orientation. }\end{array}$ & 220 \\
\hline E10. Conduct aural rehabilitation. & 10 \\
\hline E11. Monitor and summarize treatment progress and outcomes. & 17 \\
\hline $\begin{array}{l}\text { E12. Assess efficacy of interventions for auditory and balance } \\
\text { disorders. }\end{array}$ & 20 \\
\hline \multicolumn{2}{|l|}{ E13. Establish treatment admissions and discharge criteria. } \\
\hline $\begin{array}{l}\text { E14. Serve as an advocate for patients, families, and other } \\
\text { appropriate individuals. }\end{array}$ & \\
\hline
\end{tabular}


E15. Document treatment procedures and results.

E16. Maintain records in a manner consistent with legal and professional standards.

E17. Communicate results, recommendations, and progress to appropriate individuals.

E18. Use instrumentation according to manufacturers' specifications and recommendations.

E19. Determine whether instrumentation is in calibration according to accepted standards.

Table 34.

RQ1: Learned About EBP Categories, and Frequency Counts.

\begin{tabular}{|c|c|}
\hline Category & Frequency Counts \\
\hline \multicolumn{2}{|c|}{ 1A. How would you define the phrase "evidence-based practice"? } \\
\hline Defined by sources of evidence & 10 responses \\
\hline Validation of clinical practices & 6 responses \\
\hline \multicolumn{2}{|l|}{ 1B. How would you describe the purpose of EBP? } \\
\hline Application of evidence & 10 responses \\
\hline Benefits to patients from using evidence & 5 responses \\
\hline Outcome support from evidence & 3 responses \\
\hline Evidence increases quality of care & 3 responses \\
\hline Evidence is important when outcomes are questioned & 2 responses \\
\hline \multicolumn{2}{|c|}{$\begin{array}{l}\text { 1C. Do you see any benefits from writing and reading Weblogs about clinic experiences? If so } \\
\text { describe them. }\end{array}$} \\
\hline Learned from reading others & 9 responses \\
\hline Learned from sharing different experiences & 6 responses \\
\hline Distributed learning & 4 responses \\
\hline Learned about evidence and its application & 4 responses \\
\hline Confirmation of practices & 4 responses \\
\hline Share information/evidence & 3 responses \\
\hline Learned from writing & 3 responses \\
\hline Shared similar experiences & 2 responses \\
\hline Liked getting feedback & 1 responses \\
\hline
\end{tabular}




\begin{tabular}{|c|c|}
\hline Validation of clinical practices & 7 responses \\
\hline Continued Learning & 6 responses \\
\hline Improved patient care & 5 responses \\
\hline Expanded knowledge base & 2 responses \\
\hline Improved research skills & 1 responses \\
\hline \multicolumn{2}{|c|}{ 1E. What were the limitations or barriers you experienced with writing your Weblogs? } \\
\hline Selection of cases to discuss & 5 responses \\
\hline Time & 5 responses \\
\hline Technology & 4 responses \\
\hline Negativity among peers & 2 responses \\
\hline Needed guidance & 2 responses \\
\hline Consistency & 1 responses \\
\hline Limited journal/article access & 1 responses \\
\hline \multicolumn{2}{|c|}{ 1F. What limitations or barriers did you experience reading other AuD students' Weblogs? } \\
\hline None & 6 responses \\
\hline Lack of effort from peers & 5 responses \\
\hline Time & 1 responses \\
\hline Asynchronous communication & 1 responses \\
\hline \multicolumn{2}{|c|}{$\begin{array}{l}\text { 1G. Can you identify any specific clinical practices that you learned or found supported from } \\
\text { the evidence you uncovered when writing your blogs? Explain those for me, if affirmative. }\end{array}$} \\
\hline Can identify specific evidence & 4 responses \\
\hline Cannot identify any specific evidence & 4 responses \\
\hline Ability to review later & 2 responses \\
\hline \multicolumn{2}{|c|}{$\begin{array}{l}\text { 1H. Can you identify any specific clinical practices that you learned or found supported fron } \\
\text { evidence you read in another AuD student's blog? }\end{array}$} \\
\hline Cannot identify any specific evidence & 5 responses \\
\hline Can identify specific evidence & 2 responses \\
\hline Can identify general topics & 1 responses \\
\hline
\end{tabular}


Table 35.

RQ1: Select Quotes From Learned about EBP Categories.

\begin{tabular}{|c|c|}
\hline $\begin{array}{l}\text { Interview Response } \\
\text { Category }\end{array}$ & Select Quotes \\
\hline \multicolumn{2}{|c|}{ 1A. How would you define the phrase "evidence-based practice"? } \\
\hline \multirow[t]{3}{*}{$\begin{array}{l}\text { Defined by sources of } \\
\text { evidence }\end{array}$} & $\begin{array}{l}\text { "empirical evidence that has been proven statistically } \\
\text { significant” }\end{array}$ \\
\hline & “published research” \\
\hline & “studies done” \\
\hline \multirow[t]{3}{*}{$\begin{array}{l}\text { Validation of clinical } \\
\text { practices }\end{array}$} & $\begin{array}{l}\text { "support the practices that you do in your clinic with your } \\
\text { patients." }\end{array}$ \\
\hline & “...back up what you're doing clinically” \\
\hline & “...found to be the most effective ways of doing things" \\
\hline \multicolumn{2}{|c|}{ 1B. How would you describe the purpose of EBP? } \\
\hline \multirow[t]{3}{*}{ Application of evidence } & “You have to know why you're doing what you're doing.” \\
\hline & "bringing it in to your clinical practices" \\
\hline & “to evaluate everything you do critically.” \\
\hline \multirow[t]{3}{*}{$\begin{array}{l}\text { Benefits to patients from } \\
\text { using evidence }\end{array}$} & $\begin{array}{l}\text { "not putting your patients through something that isn't valid for what } \\
\text { they need or what needs to be done.” }\end{array}$ \\
\hline & “protect our patients” \\
\hline & "made us think about our patients more" \\
\hline \multirow{3}{*}{$\begin{array}{l}\text { Outcome support from } \\
\text { evidence }\end{array}$} & "better outcome for the treatments" \\
\hline & “make sure that what you're doing with patients works.” \\
\hline & "treat them in an accurate and professional way" \\
\hline \multirow{3}{*}{$\begin{array}{l}\text { Evidence increases quality of } \\
\text { care }\end{array}$} & "getting the best care." \\
\hline & "highest quality of care that they can get" \\
\hline & $\begin{array}{l}\text { "made us look into finding more answers and looking outside the box } \\
\text { to find possible solutions for what they needed" }\end{array}$ \\
\hline $\begin{array}{l}\text { Evidence is important when } \\
\text { outcomes are questioned }\end{array}$ & $\begin{array}{l}\text { "If you have a question, they ask you 'what does such and such say } \\
\text { about this?' what does evidence say about this?” }\end{array}$ \\
\hline \multicolumn{2}{|c|}{$\begin{array}{l}\text { 1C. Do you see any benefits from writing and reading Weblogs about clinic experiences? If so, } \\
\text { describe them. }\end{array}$} \\
\hline Learned from reading others & “you can learn from other people’s experiences.” \\
\hline
\end{tabular}




\begin{tabular}{|c|c|}
\hline & $\begin{array}{l}\text { "when you read their blog, you kind of have a feel for what they } \\
\text { were really doing, "cause you know them so well." }\end{array}$ \\
\hline & $\begin{array}{l}\text { "other people to look at your, what you did in a situation to see } \\
\text { how they would do it differently." }\end{array}$ \\
\hline & $\begin{array}{l}\text { "I learned a lot more by reading - I don't even know how many } \\
\text { people were participating in it - but just reading what everybody } \\
\text { else was going through.” }\end{array}$ \\
\hline & $\begin{array}{l}\text { "I read somebody's blog and the evidence they had on there was } \\
\text { on the Praxis exam." }\end{array}$ \\
\hline \multirow{3}{*}{$\begin{array}{l}\text { Learned from sharing } \\
\text { different experiences }\end{array}$} & "we each have different experiences in clinic” \\
\hline & $\begin{array}{l}\text { "people fitting a certain hearing aid and people that weren't. um, } \\
\text { a lot of people had kids, other people didn't." }\end{array}$ \\
\hline & "being able to read what they experienced" \\
\hline \multirow[t]{3}{*}{ Distributed learning } & $\begin{array}{l}\text { "what one person saw in clinic I may not have gotten to see or } \\
\text { may not ever see." }\end{array}$ \\
\hline & “you can see what all goes on out there.” \\
\hline & $\begin{array}{l}\text { "if you would do the same thing or if you had different thoughts, } \\
\text { how you would take it differently." }\end{array}$ \\
\hline \multirow{3}{*}{$\begin{array}{l}\text { Learned about evidence and } \\
\text { its application }\end{array}$} & "what evidence is out there for certain test procedures" \\
\hline & “wonder why you're doing it” \\
\hline & $\begin{array}{l}\text { "to actually understand the methodology behind what you're } \\
\text { doing." }\end{array}$ \\
\hline \multirow[t]{2}{*}{ Confirmation of practices } & “other people’s opinions as to why they used it.” \\
\hline & $\begin{array}{l}\text { "what they would have done, or if they agreed with me } \\
\text { whatsoever" }\end{array}$ \\
\hline Share information/evidence & $\begin{array}{l}\text { "they might have known more or read some kind of research on } \\
\text { it that I hadn't read" }\end{array}$ \\
\hline \multirow[t]{2}{*}{ Learned from writing } & $\begin{array}{l}\text { "you learn from your own experience in writing down what } \\
\text { you've done.” }\end{array}$ \\
\hline & "have your own thoughts down” \\
\hline Shared similar experiences & "same type of patient or the same type of situation or issue" \\
\hline Liked getting feedback & "I liked to get feedback" \\
\hline \multicolumn{2}{|c|}{ 1D. Do you see any benefits from including EBP into the Weblogs? Explain this for me. } \\
\hline \multirow{2}{*}{$\begin{array}{l}\text { Validation of clinical } \\
\text { practices }\end{array}$} & "it encouraged me to verify everything that I've done." \\
\hline & "there is way more benefit of providing the evidence" \\
\hline
\end{tabular}




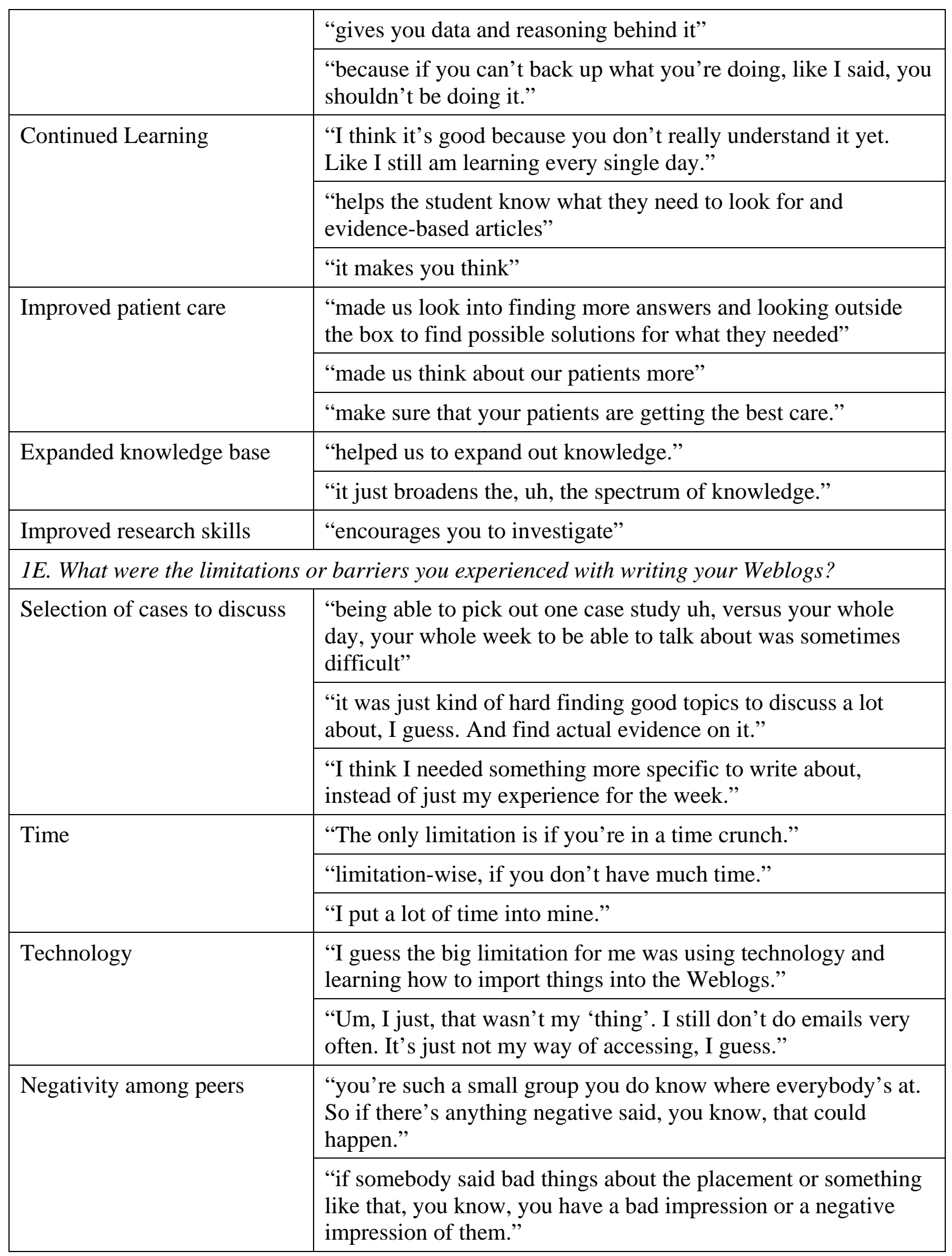




\begin{tabular}{|c|c|}
\hline \multirow[t]{2}{*}{ Needed guidance } & "I wasn’t quite sure, um, how to DO a blog." \\
\hline & "had something specific to research to put in a Weblog" \\
\hline Consistency & $\begin{array}{l}\text { "I felt that because I am not much of a journal writing type of } \\
\text { person, I wasn’t very good about keeping up on it and doing it" }\end{array}$ \\
\hline Limited journal/article access & $\begin{array}{l}\text { "There'd be an article and I'd see the abstract and I thought, you } \\
\text { know, this would be a good article to include. And } \\
\text { unfortunately, I couldn't include it without getting a paid } \\
\text { subscription to whatever journal that was.” }\end{array}$ \\
\hline \multicolumn{2}{|c|}{ 1F. What limitations or barriers did you experience reading other AuD students' Weblogs? } \\
\hline \multirow[t]{2}{*}{ None } & $\begin{array}{l}\text { "I didn’t have any limitations or barriers for reading the } \\
\text { Weblogs" }\end{array}$ \\
\hline & "I can't think of any limitations I had reading others'.” \\
\hline \multirow[t]{4}{*}{ Lack of effort from peers } & $\begin{array}{l}\text { "those that actually, you know, you could tell took the time to } \\
\text { read the entire article and research what they were doing rather } \\
\text { than just you know, skimming the article and picking out the } \\
\text { key points that they thought were important." }\end{array}$ \\
\hline & $\begin{array}{l}\text { "I thought some of them were really good and some of them } \\
\text { really lacked effort." }\end{array}$ \\
\hline & $\begin{array}{l}\text { "I would get really irritated when I would look and see that } \\
\text { someone used Wikipedia or something that wasn’t empirical } \\
\text { evidence." }\end{array}$ \\
\hline & $\begin{array}{l}\text { "if the person writing the Weblog had just kinda done a website } \\
\text { search instead of actually using a published journal" }\end{array}$ \\
\hline Time & “just the time involved in reading everyone’s” \\
\hline $\begin{array}{l}\text { Asynchronous } \\
\text { communication }\end{array}$ & $\begin{array}{l}\text { "how they got from point A to point B um, you know, } \\
\text { sometimes was muddy and, you know, reading it versus talking } \\
\text { about it is, is sort of difficult. Because you can’t ask questions, } \\
\text { you know, right off hand as you're reading it. Versus just being } \\
\text { able to discuss it like in a real live classroom.” }\end{array}$ \\
\hline \multicolumn{2}{|c|}{$\begin{array}{l}\text { 1G. Can you identify any specific clinical practices that you learned or found supported from } \\
\text { the evidence you uncovered when writing your blogs? Explain those for me, if affirmative. }\end{array}$} \\
\hline \multirow[t]{3}{*}{$\begin{array}{l}\text { Can identify specific } \\
\text { evidence }\end{array}$} & $\begin{array}{l}\text { "I can remember some VNG articles cause that's usually what } \\
\text { I'm lacking” }\end{array}$ \\
\hline & "I did one on eNoG that really helped me" \\
\hline & "real ear measures in one that really helped" \\
\hline \multirow{2}{*}{$\begin{array}{l}\text { Cannot identify any specific } \\
\text { evidence }\end{array}$} & “I don’t know that I can pinpoint any.” \\
\hline & "nothing specific that I can recall off the top of my head" \\
\hline
\end{tabular}




\begin{tabular}{|c|c|}
\hline & “I don’t remember specifically what it was I learned” \\
\hline Ability to review later & $\begin{array}{l}\text { "you can go back and read what you did and kind of get a new } \\
\text { perspective" }\end{array}$ \\
\hline \multicolumn{2}{|c|}{$\begin{array}{l}\text { 1H. Can you identify any specific clinical practices that you learned or found supported from } \\
\text { evidence you read in another AuD student's blog? }\end{array}$} \\
\hline \multirow[t]{2}{*}{$\begin{array}{l}\text { Cannot identify any specific } \\
\text { evidence }\end{array}$} & $\begin{array}{l}\text { "I know for sure that I learned from other people, I just can’t } \\
\text { remember specific client." }\end{array}$ \\
\hline & $\begin{array}{l}\text { "I know that I learned a bunch of stuff but I can’t specifically say } \\
\text { what I learned from the others'.” }\end{array}$ \\
\hline \multirow{2}{*}{$\begin{array}{l}\text { Can identify specific } \\
\text { evidence }\end{array}$} & “it was about cholesteatomas.” \\
\hline & “some VNG articles” \\
\hline Can identify general topics & $\begin{array}{l}\text { "what signs do you look for? why would you suspect this? What do } \\
\text { you do if you suspect this?” }\end{array}$ \\
\hline
\end{tabular}




\section{Appendix E}

Tabular Results of Research Question 2 Data

Table 36.

RQ2: Reactions to Weblogs Interview Categories and Frequency Counts.

\begin{tabular}{|c|c|}
\hline Categories & Frequency Counts \\
\hline \multicolumn{2}{|c|}{ 2A. Tell me what your initial reactions to the Weblog assignment were. } \\
\hline Something else to do & 6 \\
\hline Didn't want to do it & 4 \\
\hline Technology barriers & 4 \\
\hline Expected exciting & 3 \\
\hline Social learning & 3 \\
\hline Uncertain expectations & 3 \\
\hline Time barriers & 1 \\
\hline \multicolumn{2}{|c|}{ 2B. Did you opinion of the assignment change over time? } \\
\hline Opinion changed & 6 \\
\hline Considered it a large effort & 5 \\
\hline Social learning & 3 \\
\hline Beneficial & 3 \\
\hline Interested & 3 \\
\hline No change in opinion & 2 \\
\hline Still didn’t want to & 2 \\
\hline Small effort & 1 \\
\hline Good experience & 1 \\
\hline Still exciting & 1 \\
\hline \multicolumn{2}{|c|}{ 2C. What was your favorite aspect of the blog assignment? } \\
\hline Liked reading peers' blogs & 5 \\
\hline Learned & 4 \\
\hline Liked personal reflection & 3 \\
\hline Liked getting feedback & 2 \\
\hline Creativity & 1 \\
\hline
\end{tabular}




\begin{tabular}{|c|c|}
\hline Liked funny stories & 1 \\
\hline \multicolumn{2}{|c|}{ 2D. What was your lease favorite aspect of the blog assignment? } \\
\hline Writing blog was challenging & 10 \\
\hline Negative experiences & 4 \\
\hline Didn’t like additional work & 1 \\
\hline Unfamiliar with technology & 1 \\
\hline \multicolumn{2}{|c|}{ 2E. What recommendations would you make regarding the blog assignment? } \\
\hline More demonstration of the assignment & 6 \\
\hline Specific requirements & 5 \\
\hline More clinical experiences & 1 \\
\hline Grading & 1 \\
\hline No recommendations & 1 \\
\hline \multicolumn{2}{|c|}{$2 F$. Is there anything else about the blog assignment that you want to tell me? } \\
\hline Positive experience & 4 \\
\hline Didn’t want to & 3 \\
\hline Think requirements are needed. & 2 \\
\hline Technology issues & 2 \\
\hline Learning occurred & 2 \\
\hline Initial barriers & 2 \\
\hline
\end{tabular}

Table 37.

RQ2: Select Quotes From Weblog reactions Categories.

\begin{tabular}{|l|l|}
\hline \multicolumn{1}{|c|}{ Categories } & \multicolumn{1}{c|}{ Quotes } \\
\hline 2A. Tell me what your initial reactions to the Weblog assignment were. \\
\hline Something else to do & "I honestly felt that it was just another thing to do.” \\
\cline { 2 - 3 } & "I just thought it was one more thing to add on to the pile.” \\
\cline { 2 - 3 } & $\begin{array}{l}\text { "initial reaction was 'Oh god there’s something else I have to } \\
\text { do.” }\end{array}$ \\
\cline { 2 - 2 } & "I was overwhelmed” \\
\hline Didn’t want to do it & "Well, I didn’t want to do it.” \\
\cline { 2 - 2 } & "My initial reaction was definitely like, "Ahhh! What for?’” \\
\hline
\end{tabular}




\begin{tabular}{|c|c|}
\hline \multirow[t]{2}{*}{ Technology barriers } & $\begin{array}{l}\text { "I’ve never been the type of person that's constantly on the } \\
\text { Internet or anything like that, so. . . I think that was what } \\
\text { differentiated me a little bit." }\end{array}$ \\
\hline & “I couldn't remember how to get in there all the time." \\
\hline \multirow[t]{2}{*}{ Expected exciting } & "I thought it was an exciting thing." \\
\hline & $\begin{array}{l}\text { "thought it was something that was going to be um, you know, I } \\
\text { hate to use the word innovative, but something that was not } \\
\text { exactly um, you know, the status quo for what we'd been doing" }\end{array}$ \\
\hline \multirow[t]{2}{*}{ Social learning } & $\begin{array}{l}\text { "I actually found this as a good outlet to be able to you know, } \\
\text { learn from other people, see what other people were } \\
\text { experiencing" }\end{array}$ \\
\hline & $\begin{array}{l}\text { "what kind of patients each individual AuD student was, um, } \\
\text { you know, the kind of demographics that they were seeing and } \\
\text { how I could learn from their experiences." }\end{array}$ \\
\hline \multirow[t]{3}{*}{ Uncertain expectations } & "I was confused because I had never blogged before.” \\
\hline & $\begin{array}{l}\text { "what was supposed to be written in a blog, etc. and that was } \\
\text { explained to an extent, but, I wasn’t even sure what it should } \\
\text { consist of.” }\end{array}$ \\
\hline & $\begin{array}{l}\text { "I didn't even really know what a blog was, what a Weblog was } \\
\text { when we got the assignment" }\end{array}$ \\
\hline Time barriers & “very time consuming thing.” \\
\hline \multicolumn{2}{|c|}{ 2B. Did you opinion of the assignment change over time? } \\
\hline \multirow[t]{3}{*}{ Opinion changed } & “Absolutely.” \\
\hline & “Yeah, definitely.” \\
\hline & "Yeah, it did because I did find it informative." \\
\hline \multirow[t]{3}{*}{ Considered it a large effort } & $\begin{array}{l}\text { "Just picking out specific clients and figuring out what I was } \\
\text { going to do, but as I did it over time, it became easier." }\end{array}$ \\
\hline & $\begin{array}{l}\text { "any time something's new, it's hard and you don't want to do it } \\
\text { and you don't want to figure it out." }\end{array}$ \\
\hline & $\begin{array}{l}\text { "Especially if you're doing what you're supposed to actually sit } \\
\text { down to do." }\end{array}$ \\
\hline \multirow[t]{2}{*}{ Social learning } & $\begin{array}{l}\text { "I got to read different articles, and learn more evidence based } \\
\text { stuff off of everybody else's articles including the stuff that I } \\
\text { was researching” }\end{array}$ \\
\hline & $\begin{array}{l}\text { "what other kind of, um, you know, knowledge that they were } \\
\text { gaining from their uh supervisors and such that I could put into } \\
\text { my own" }\end{array}$ \\
\hline
\end{tabular}




\begin{tabular}{|c|c|}
\hline \multirow[t]{3}{*}{ Beneficial } & $\begin{array}{l}\text { "I realized that it was really just to teach us what to look for and } \\
\text { how to back up our opinions" }\end{array}$ \\
\hline & "but you can’t deny that they’re beneficial” \\
\hline & $\begin{array}{l}\text { "the more I did them, the effort I put into them, the more I } \\
\text { realized how important it actually was." }\end{array}$ \\
\hline \multirow[t]{2}{*}{ Interested } & $\begin{array}{l}\text { "I found my self almost looking to see who was writing } \\
\text { something new to see if I could somehow draw from it to put } \\
\text { into practice for myself" }\end{array}$ \\
\hline & $\begin{array}{l}\text { "thinking about, you know, "Oh, I have an interesting case to } \\
\text { write about. I'm gonna go ahead and do that." And I did it as } \\
\text { soon as I saw the patient so it was fresh in my mind" }\end{array}$ \\
\hline No change in opinion & “Not really, I don’t think so” \\
\hline Still didn’t want to & "By the end, I mean, you still don't want to sit down and do it." \\
\hline Considered it a small effort & $\begin{array}{l}\text { "you were not asking a lot of us. It was not anything so horrific } \\
\text { that we could not do it. You know, it was just } 10 \text { minutes of our } \\
\text { time." }\end{array}$ \\
\hline Good experience & "I did like being able to read other people’s experience" \\
\hline Still was exciting & $\begin{array}{l}\text { "every time it was, it was still something that was fresh and } \\
\text { worthwhile.” }\end{array}$ \\
\hline \multicolumn{2}{|c|}{ 2C. What was your favorite aspect of the blog assignment? } \\
\hline \multirow[t]{3}{*}{ Liked reading peers’ blogs } & “I would say reading everybody else’s.” \\
\hline & $\begin{array}{l}\text { "being able to go in and read everyone's information and their } \\
\text { thoughts on, on different situations of their week in clinic." }\end{array}$ \\
\hline & $\begin{array}{l}\text { "I liked to know that other people were having the same } \\
\text { experiences as me. It made me feel more connected and not so } \\
\text { alone with experiences” }\end{array}$ \\
\hline \multirow[t]{2}{*}{ Learned } & $\begin{array}{l}\text { "the ability to prepare ourselves for the real world and how we } \\
\text { would work with other audiologists in the state is very } \\
\text { important." }\end{array}$ \\
\hline & $\begin{array}{l}\text { "if that involved criticism, then you know, my feeling was 'so } \\
\text { be it'. That's you know, constructive criticism.” }\end{array}$ \\
\hline \multirow[t]{2}{*}{ Liked personal reflection } & $\begin{array}{l}\text { "I think I just really liked uh, reflecting on the interesting cases I } \\
\text { saw during the week" }\end{array}$ \\
\hline & $\begin{array}{l}\text { "To actually sit there and think, you know, this is an interesting } \\
\text { case - why did I do this?” }\end{array}$ \\
\hline Liked getting feedback & “truthfully probably getting the feedback.” \\
\hline
\end{tabular}




\begin{tabular}{|c|c|}
\hline & $\begin{array}{l}\text { "to kind of just look at what other people doing, comment on it, } \\
\text { and to see - get other aspects" }\end{array}$ \\
\hline Creativity & “Being able to be creative and design your webpage.” \\
\hline Liked funny stories & $\begin{array}{l}\text { "probably reading funny stories. I love hearing people, other } \\
\text { people’s funny stories.” }\end{array}$ \\
\hline \multicolumn{2}{|c|}{ 2D. What was your lease favorite aspect of the blog assignment? } \\
\hline \multirow[t]{5}{*}{ Writing blog was challenging } & $\begin{array}{l}\text { "I had to come up with something kind of, you wanted to be a } \\
\text { little attention-getting so people would want to read them," }\end{array}$ \\
\hline & "Having to write my own” \\
\hline & "Writing and researching them." \\
\hline & $\begin{array}{l}\text { "like you sit there and ask around, like what can I say that will } \\
\text { peak interest here." }\end{array}$ \\
\hline & $\begin{array}{l}\text { "really just trying to pick one or two experiences out of a full } \\
\text { week to talk about" }\end{array}$ \\
\hline \multirow[t]{3}{*}{ Negative experiences } & $\begin{array}{l}\text { "it was a little discouraging to see how some people didn’t put } \\
\text { as much effort into it" }\end{array}$ \\
\hline & “My least favorite was just if I had a boring week.” \\
\hline & $\begin{array}{l}\text { "you couldn't really be open and free on the Weblog about } \\
\text { discussing that with the other students for fear that...., maybe a } \\
\text { fear that wouldn't have happened but you mentally thought } \\
\text { "well OK, are they gonna read this and make a comment of it } \\
\text { next time I go in?” }\end{array}$ \\
\hline Didn’t like additional work & $\begin{array}{l}\text { "Adding another.... A “quote - unquote report” onto the weekly } \\
\text { assignment.” }\end{array}$ \\
\hline Unfamiliar with technology & “we were like “what’s a blog?”” \\
\hline \multicolumn{2}{|c|}{ 2E. What recommendations would you make regarding the blog assignment? } \\
\hline \multirow[t]{4}{*}{$\begin{array}{l}\text { More demonstration of the } \\
\text { assignment }\end{array}$} & $\begin{array}{l}\text { "it took awhile for you to get the point to everyone that it was } \\
\text { supposed to be a scholarly journal and a published journal to } \\
\text { support it instead of just a website or, you know, just a } \\
\text { webpage" }\end{array}$ \\
\hline & $\begin{array}{l}\text { "maybe read them one of the more interesting ones that you've } \\
\text { had in the past" }\end{array}$ \\
\hline & "I would probably want to do one as a group." \\
\hline & $\begin{array}{l}\text { "what key words to use. I mean basically it was just the practice. } \\
\text { I don't know, I mean, maybe the best search engines you could } \\
\text { put up there you know, this is where most of your articles can be } \\
\text { found. Or you know, maybe just specific web bases or } \\
\text { something to search.” }\end{array}$ \\
\hline
\end{tabular}




\begin{tabular}{|c|c|}
\hline \multirow[t]{3}{*}{ Specific requirements } & $\begin{array}{l}\text { "I think stricter is the wrong word, but having more, something } \\
\text { more specified," }\end{array}$ \\
\hline & $\begin{array}{l}\text { "I think you'd really have to put your foot down and say 'this is } \\
\text { how it has to be done, this is, you know, protocol of what you } \\
\text { have to include," }\end{array}$ \\
\hline & $\begin{array}{l}\text { "I think that would have helped me participate a little bit more } \\
\text { in it where we had uh, questions to answer about each article." }\end{array}$ \\
\hline More clinical experiences & $\begin{array}{l}\text { "I think it's more interesting if you have a bunch of different } \\
\text { you know, clinical experiences to talk about," }\end{array}$ \\
\hline Grading & $\begin{array}{l}\text { "to take it seriously, I think um, grading would probably have to } \\
\text { be a little more stricter." }\end{array}$ \\
\hline No recommendations & $\begin{array}{l}\text { "I don’t really think I really have any recommendations right } \\
\text { now." }\end{array}$ \\
\hline \multicolumn{2}{|c|}{$2 F$. Is there anything else about the blog assignment that you want to tell me? } \\
\hline \multirow[t]{3}{*}{ Positive experience } & "I looked at it as a positive, positive endeavor." \\
\hline & $\begin{array}{l}\text { "a couple of times I may have written something that someone } \\
\text { disagreed with and they brought out a good point to it." }\end{array}$ \\
\hline & $\begin{array}{l}\text { "I thought it was a good jump start and I think it's a good idea } \\
\text { now" }\end{array}$ \\
\hline \multirow[t]{2}{*}{ Didn't want to } & "I don't think any student wants to do anything that's work." \\
\hline & "I think for me it was just procrastinating," \\
\hline \multirow{2}{*}{$\begin{array}{l}\text { Think requirements are } \\
\text { needed. }\end{array}$} & "I did it because that was what I was supposed to do." \\
\hline & $\begin{array}{l}\text { "I also think that it's not a bad requirement to make, you know, } \\
\text { just a - other than just due this day, um, a requirement that you } \\
\text { have to respond to a certain number of people’s blogs, um, a } \\
\text { week" }\end{array}$ \\
\hline \multirow[t]{2}{*}{ Technology issues } & $\begin{array}{l}\text { "me on the tail end of a generation that didn’t really grow up } \\
\text { using computers all the time." }\end{array}$ \\
\hline & $\begin{array}{l}\text { "from generations on this is actually gonna be a great idea and } \\
\text { this how they're going to communicate information back and } \\
\text { forth, whereas it was just the beginning for us." }\end{array}$ \\
\hline \multirow[t]{2}{*}{ Learning occurred } & $\begin{array}{l}\text { "the further along you get, you start realizing that, you know, } \\
\text { the stuff in there is important. You kind of, you know, I, I } \\
\text { learned a lot from um certain blogs." }\end{array}$ \\
\hline & $\begin{array}{l}\text { "brought out and a few times, somebody actually provided an } \\
\text { additional resource for me, so people were actually paying } \\
\text { attention and doing more research on their own." }\end{array}$ \\
\hline
\end{tabular}




\begin{tabular}{|l|l|}
\hline Initial barriers & $\begin{array}{l}\text { “Maybe at the beginning it was a little bit hard because you had } \\
\text { to - I wasn't sure how to search, you know, do a good thorough } \\
\text { search” }\end{array}$ \\
\hline $\begin{array}{l}\text { "think maybe towards the beginning it was a little bit of a time } \\
\text { constraint, but not once you did it and got into the swing of } \\
\text { things" }\end{array}$ \\
\hline
\end{tabular}




\section{Appendix F}

Tabular Results of Research Question 3 Data

Table 38.

RQ3: Reactions to Evidence-Based Practice Interview Categories and Frequency Counts.

\begin{tabular}{|l|l|}
\hline \multicolumn{1}{|c|}{ Categories } & \multicolumn{1}{|c|}{ Frequency Counts } \\
\hline 3A. What have you learned in your courses about evidence-based practice? \\
\hline General use of evidence & 5 \\
\hline Didn't know how to read research & 4 \\
\hline Limited exposure & 3 \\
\hline Universal need for EBP & 2 \\
\hline Research course & 2 \\
\hline Evidence from courses (saved) & 1 \\
\hline Some undergrad exposure to EBP & 1 \\
\hline Don't remember & 1 \\
\hline 3B. Did the blog assignment help you learn about evidence-based practice? How? \\
\hline Learned use of evidence & 4 \\
\hline Found sources of evidence & 3 \\
\hline Previously unfamiliar with the term EBP & 3 \\
\hline Didn't do the EBP component of the blog assignment & 3 \\
\hline Learned how to find evidence & 2 \\
\hline $\begin{array}{l}\text { 3C. Have you read any journal articles or textbook information about evidence-based practice? } \\
\text { Tell me about what you've read. }\end{array}$ & 5 \\
\hline Specific evidence found. & 4 \\
\hline No readings on EBP & 3 \\
\hline Saved evidence (this is related to the next question) & 2 \\
\hline Unspecified evidence found & 2 \\
\hline Evidence disproves some practices & 2 \\
\hline May be questioned about practices & 2 \\
\hline Don't remember & 7 \\
\hline 3D. Have you saved any specific evidence that you think you may use in the future? \\
\hline Specific evidence saved & 2 \\
\hline
\end{tabular}




\begin{tabular}{|l|l|}
\hline Scholarly work & 3 \\
\hline Evidence changes & 2 \\
\hline Discussion of evidence & 2 \\
\hline Have observed evidence disregarded at clinic sites & 2 \\
\hline Evidence saved to answer questions about practices & 2 \\
\hline $\begin{array}{l}\text { 3E. Have you thought about how you will implement evidence-based practice when working as } \\
\text { an audiologist? }\end{array}$ & 5 \\
\hline Have thought about applying EBP & 4 \\
\hline Current sources of Evidence & 3 \\
\hline No thoughts on applying EBP & 3 \\
\hline Identified specific clients or applications of evidence & 2 \\
\hline Why they are applying EBP & 2 \\
\hline Individual motivation for EBP & 1 \\
\hline 3F. How do you think evidence-based practice should be taught in AuD programs? \\
\hline Already being taught EBP, even if not called EBP & 7 \\
\hline Should be in every course /class & 4 \\
\hline Students don't understand research & 4 \\
\hline EBP should be modeled & 2 \\
\hline Need research skills & 2 \\
\hline Want research course related to audiology & 2 \\
\hline Use research from courses to learn EBP & 1 \\
\hline Want intro to technology & 1 \\
\hline Specifically in favor of the Weblog & 1 \\
\hline $\begin{array}{l}\text { 3G. What recommendations would you have for our AuD program, regarding teaching evidence- } \\
\text { based practice? }\end{array}$ & 12 \\
\hline Help students understand research & 6 \\
\hline More exposure to EBP in clinics & 6 \\
\hline Technology use & 2 \\
\hline Emphasis on EBP & 1 \\
\hline Use clinic protocols & 1 \\
\hline Universal application of EBP needed & \multicolumn{2}{|l|}{} \\
\hline Already doing a good job & \multicolumn{2}{|l|}{} \\
\hline
\end{tabular}




\begin{tabular}{|c|c|}
\hline \multicolumn{2}{|c|}{$\begin{array}{l}\text { 3H. What recommendations would you make with regards to the evidence-based practice } \\
\text { component of the Weblog assignment? }\end{array}$} \\
\hline Emphasize importance of EBP & 3 \\
\hline Student responsibility for their learning & 3 \\
\hline Clear expectations & 3 \\
\hline \multicolumn{2}{|c|}{$\begin{array}{l}\text { 3I. Does/did more need to be done in your graduate courses to expose you to evidence-based } \\
\text { practice? }\end{array}$} \\
\hline Emphasize reason for EBP & 7 \\
\hline How to use in courses & 4 \\
\hline Weblog assignment & 2 \\
\hline Use term EBP in the classroom & 1 \\
\hline Student responsibility & 1 \\
\hline Already doing a good job & 1 \\
\hline \multicolumn{2}{|c|}{$\begin{array}{l}\text { 3J. Does/did more need to be done in your clinical practicum to expose you to evidence-based } \\
\text { practice? }\end{array}$} \\
\hline Want more exposure in clinical practicum & 6 \\
\hline Have observed evidence ignored in clinic & 5 \\
\hline Want EBP modeled & 4 \\
\hline Collaboration between courses and clinic & 2 \\
\hline Suggestions to in corporate EBP in clinic & 2 \\
\hline Need to be taught research skills & 1 \\
\hline \multicolumn{2}{|c|}{ 3K. Is there anything else about evidence-based practice that you want to tell me? } \\
\hline More exposure to EBP needed & 5 \\
\hline Need to see EBP modeled & 4 \\
\hline Support application of EBP & 4 \\
\hline Resisted the work & 3 \\
\hline Suggestions for EBP blog assignment & 3 \\
\hline Research skills have develop & 1 \\
\hline Positive aspect of blogs & 1 \\
\hline
\end{tabular}


Table 39.

RQ3: Select Quotes From Reactions to Evidence-Based Practice Interview Categories.

\begin{tabular}{|c|c|}
\hline Categories & Quotes \\
\hline \multicolumn{2}{|c|}{ 3A. What have you learned in your courses about evidence-based practice? } \\
\hline \multirow[t]{4}{*}{ General use of evidence } & $\begin{array}{l}\text { "professors would present information and then, say, ask me } \\
\text { why. And then if you said you didn’t know why, they would say } \\
\text { well then you need to research that and support what you're } \\
\text { doing. So in my courses, it was acknowledged that you need to } \\
\text { provide support and reasoning for what you're doing with } \\
\text { patients.” }\end{array}$ \\
\hline & $\begin{array}{l}\text { "what is a strong um, evidence-supported article. And what } \\
\text { makes a weak one" }\end{array}$ \\
\hline & $\begin{array}{l}\text { “"Prof X” was big on making sure you had references outside of } \\
\text { textbooks.” }\end{array}$ \\
\hline & "I think everything that we're taught is obviously EBP," \\
\hline \multirow[t]{2}{*}{$\begin{array}{l}\text { Didn't know how to read } \\
\text { research }\end{array}$} & $\begin{array}{l}\text { "in the beginning nobody really reads them because you don't } \\
\text { want to and half of it you really don't understand" }\end{array}$ \\
\hline & $\begin{array}{l}\text { “I remember saying to you even one day 'I can read a whole } \\
\text { research paper.' And I actually got it.” }\end{array}$ \\
\hline \multirow[t]{2}{*}{ Limited exposure } & $\begin{array}{l}\text { "Evidence-based practice....um, you know, I don’t know that I } \\
\text { can answer that one.” }\end{array}$ \\
\hline & $\begin{array}{l}\text { "other than that we didn't get into specifics about evidence- } \\
\text { based practice” }\end{array}$ \\
\hline \multirow[t]{2}{*}{ Universal need for EBP } & $\begin{array}{l}\text { "we've gone over just how it is important to have the research to } \\
\text { back up you know, what we're doing in clinic.” }\end{array}$ \\
\hline & “ASHA supported EBP.” \\
\hline Research course & $\begin{array}{l}\text { "did have that one research course where they touched on it a } \\
\text { little bit and gave us some of the equations to use" }\end{array}$ \\
\hline Evidence from courses saved & $\begin{array}{l}\text { "you still have it. And I still have all of that stuff. So, you know, } \\
\text { now that I can read it, and actually understand it, you still have } \\
\text { it and it's still important." }\end{array}$ \\
\hline $\begin{array}{l}\text { Some undergrad exposure to } \\
\text { EBP }\end{array}$ & "had a brief introduction to EBP in undergraduate school." \\
\hline Don’t remember & "I have no idea. I’ve been out too long” \\
\hline \multicolumn{2}{|c|}{ 3B. Did the blog assignment help you learn about evidence-based practice? How? } \\
\hline Learned use of evidence & "know exactly why that test is valid for this particular patient." \\
\hline
\end{tabular}




\begin{tabular}{|c|c|}
\hline & "helped me realize that you need to research these things" \\
\hline & $\begin{array}{l}\text { "we have our knowledge, we put it into play and these are the } \\
\text { possible outcomes. So um, you know, by reading others } \\
\text { examples, you know, I just got more, uh, more input in my own } \\
\text { uh, possible idea of where it would go." }\end{array}$ \\
\hline \multirow[t]{2}{*}{ Found sources of evidence } & $\begin{array}{l}\text { "how to search for good EBP article, and you know, what to } \\
\text { look for when it's not a true - you know, when it's just like an } \\
\text { opinion that's out there." }\end{array}$ \\
\hline & "helped me learn how to find answers." \\
\hline \multirow[t]{3}{*}{$\begin{array}{l}\text { Previously unfamiliar with } \\
\text { the term EBP }\end{array}$} & $\begin{array}{l}\text { "I didn’t even really know what the definition of it was before I } \\
\text { started doing the blogs" }\end{array}$ \\
\hline & $\begin{array}{l}\text { "I think that it was the first time I had heard the term 'evidence- } \\
\text { based practice”" }\end{array}$ \\
\hline & $\begin{array}{l}\text { "I know we learned about stuff in classes, but I don’t think they } \\
\text { ever used that terminology” }\end{array}$ \\
\hline $\begin{array}{l}\text { Didn't do the EBP } \\
\text { component of the blog } \\
\text { assignment }\end{array}$ & “we weren’t doing much of that” \\
\hline Learned how to find evidence & $\begin{array}{l}\text { "what to look for when it's not a true - you know, when it's just } \\
\text { like an opinion that's out there" }\end{array}$ \\
\hline \multicolumn{2}{|c|}{$\begin{array}{l}\text { 3C. Have you read any journal articles or textbook information about evidence-based practice? } \\
\text { Tell me about what you've read. }\end{array}$} \\
\hline \multirow[t]{3}{*}{ Specific evidence found. } & "the whole journal was based on evidence-based," \\
\hline & $\begin{array}{l}\text { "especially stuff on BPPV, um, stuff on different types of } \\
\text { canilith remove-um, repositioning" }\end{array}$ \\
\hline & $\begin{array}{l}\text { "had to do an EBP in your supervision course. I think we read } \\
\text { an article about it and I've read some editorials about EBP }\end{array}$ \\
\hline \multirow[t]{3}{*}{ No readings on EBP } & $\begin{array}{l}\text { "I haven't seen anything current. And usually I read a lot of the } \\
\text { audiology magazines and journals." }\end{array}$ \\
\hline & “Not lately, I don’t think” \\
\hline & $\begin{array}{l}\text { "outside of the stuff that we did for the blogs, I haven't come } \\
\text { into contact with any, no" }\end{array}$ \\
\hline \multirow[t]{3}{*}{$\begin{array}{l}\text { Saved evidence (this is } \\
\text { related to the next question) }\end{array}$} & $\begin{array}{l}\text { "I gathered as much information that I possibly could get to } \\
\text { have." }\end{array}$ \\
\hline & "I have all kinds of stuff that I keep in a folder" \\
\hline & "oh I have all kinds of stuff." \\
\hline Unspecified evidence found & "some articles where they discussed using EBP and, how it \\
\hline
\end{tabular}




\begin{tabular}{|c|c|}
\hline & $\begin{array}{l}\text { should be used in medicine, etc. and the downfalls of using it } \\
\text { when it comes to insurances and stuff" }\end{array}$ \\
\hline \multirow[t]{2}{*}{$\begin{array}{l}\text { Evidence disproves some } \\
\text { practices }\end{array}$} & $\begin{array}{l}\text { "pointing out that if you did research, you would discontinue } \\
\text { that practice." }\end{array}$ \\
\hline & $\begin{array}{l}\text { "people recommending that audiologists do research about their } \\
\text { practices and things that have been proven to be ineffective." }\end{array}$ \\
\hline $\begin{array}{l}\text { May be questioned about } \\
\text { practices }\end{array}$ & $\begin{array}{l}\text { “doctors will ask you why you're doing things a certain way. } \\
\text { And if you don’t have it, you know, you just don’t have } \\
\text { anything.” }\end{array}$ \\
\hline Don’t remember & $\begin{array}{l}\text { "I'm sure I read things in classes, and then just in passing, } \\
\text { reading things. But I don't know specifically what it was." }\end{array}$ \\
\hline \multicolumn{2}{|c|}{ 3D. Have you saved any specific evidence that you think you may use in the future? } \\
\hline \multirow[t]{3}{*}{ Specific evidence saved } & "But I have stuff. I have everything I ever worked on.” \\
\hline & $\begin{array}{l}\text { "I remember one in particular that it was like a "Wow", um, that } \\
\text { I hadn’t read before. That after you do the Epley maneuver for } \\
\text { BPPV it is not necessary to wear a neck brace or sit upright" }\end{array}$ \\
\hline & $\begin{array}{l}\text { "I gathered as much information that I possibly could get to } \\
\text { have. Um, especially stuff on BPPV" }\end{array}$ \\
\hline \multirow[t]{2}{*}{ Scholarly work } & “Yes, for my scholarly work” \\
\hline & “Stuff on what I’m doing for my scholarly work.” \\
\hline Evidence changes & $\begin{array}{l}\text { "amazing that that actually changes. It's so simple but } \\
\text { everything changes.” }\end{array}$ \\
\hline Discussion of evidence & $\begin{array}{l}\text { "general reading, especially with a few of the students that had } \\
\text { some cases, some retrocochlear pathologies and such, um, you } \\
\text { know, just, just from general knowledge how they dealt with it } \\
\text { and how their supervisors suggested dealing with it, I definitely } \\
\text { learned some things I've put into practice." }\end{array}$ \\
\hline \multirow[t]{2}{*}{$\begin{array}{l}\text { Have observed evidence } \\
\text { disregarded at clinic sites }\end{array}$} & $\begin{array}{l}\text { "I went to a place that still did it and I was, like, I shared it with } \\
\text { them and um, you know, they were like, "Oh."”" }\end{array}$ \\
\hline & “the reaction pretty much was, “That’s how we do it.”” \\
\hline $\begin{array}{l}\text { Evidence saved to answer } \\
\text { questions about practices }\end{array}$ & "all research that I can go to any time anybody has a question" \\
\hline \multicolumn{2}{|c|}{$\begin{array}{l}\text { 3E. Have you thought about how you will implement evidence-based practice when working as } \\
\text { an audiologist? }\end{array}$} \\
\hline \multirow{2}{*}{$\begin{array}{l}\text { Have thought about applying } \\
\text { EBP }\end{array}$} & "I support everything that I do with research.” \\
\hline & $\begin{array}{l}\text { "I think I do use EBP. I do research information if I'm not sure } \\
\text { and try to find the best information out there on a subject." }\end{array}$ \\
\hline
\end{tabular}




\begin{tabular}{|c|c|}
\hline & $\begin{array}{l}\text { "Yeah, I mean I definitely being in the positions that I am, I } \\
\text { definitely have to be on guard and be able to explain anything at } \\
\text { any time. I even have PT's that I talk to and um, we give articles } \\
\text { back and forth" }\end{array}$ \\
\hline \multirow[t]{2}{*}{ Current sources of Evidence } & $\begin{array}{l}\text { "I get to find out new and interesting things and um, go to } \\
\text { conferences, and get experience - um, seminars, and get } \\
\text { continuing education, and constantly finding things interesting." }\end{array}$ \\
\hline & $\begin{array}{l}\text { "right now, my main resources are the internet, which mainly is } \\
\text { journal articles and what people have published. And journal } \\
\text { articles that I get, um, regular journals in the mail" }\end{array}$ \\
\hline \multirow[t]{2}{*}{ No thoughts on applying EBP } & "No I have not honestly thought about that." \\
\hline & “No, I can’t say that I have” \\
\hline $\begin{array}{l}\text { Identified specific clients or } \\
\text { applications of evidence }\end{array}$ & $\begin{array}{l}\text { "he's not like every other patient, so I need to see why I need to } \\
\text { do this certain test or this certain treatment for this person" }\end{array}$ \\
\hline Why they are applying EBP & $\begin{array}{l}\text { "Site X, they follow protocol, too. If you can't, if you can’t back } \\
\text { up what you're doing then you're strongly encouraged to find } \\
\text { out why.” }\end{array}$ \\
\hline $\begin{array}{l}\text { Individual motivation for } \\
\text { EBP }\end{array}$ & $\begin{array}{l}\text { "I want to look into finding what everybody else in I guess the } \\
\text { world, or the country, is doing" }\end{array}$ \\
\hline \multicolumn{2}{|c|}{ 3F. How do you think evidence-based practice should be taught in AuD programs? } \\
\hline \multirow[t]{4}{*}{$\begin{array}{l}\text { Already being taught EBP, } \\
\text { even if not called EBP }\end{array}$} & $\begin{array}{l}\text { "I think that we're doing that. It just doesn't come out as EBP - } \\
\text { you know, those words.” }\end{array}$ \\
\hline & $\begin{array}{l}\text { "I’ve been taught EBP from day-one of graduate school but it’s } \\
\text { not conveyed in those terms.” }\end{array}$ \\
\hline & $\begin{array}{l}\text { "I think it is being taught throughout all the classes. It's just not } \\
\text { being stated as being taught EBP." }\end{array}$ \\
\hline & $\begin{array}{l}\text { "I think it is. It might not be specifically stated as using EBP. } \\
\text { But I mean I think it always is in some shape or form because } \\
\text { we look up the research, we have um, quoted research behind a } \\
\text { lot of what we do, why to choose this procedure and why we use } \\
\text { the procedure" }\end{array}$ \\
\hline \multirow{3}{*}{$\begin{array}{l}\text { Should be in every course } \\
\text { /class }\end{array}$} & "I think it should be an integral part of every class." \\
\hline & $\begin{array}{l}\text { "every professor or you know, every level is going to have to } \\
\text { start implementing it in some way or the other." }\end{array}$ \\
\hline & $\begin{array}{l}\text { "every professor should step and make some kind of point and } \\
\text { try to squeeze it in there, even if it's just uh, one afternoon or } \\
\text { something." }\end{array}$ \\
\hline $\begin{array}{l}\text { Students don't understand } \\
\text { research }\end{array}$ & $\begin{array}{l}\text { "just even how to read the graphs and stuff in those. That sounds } \\
\text { crazy too, but like you really just don't get it for a while." }\end{array}$ \\
\hline
\end{tabular}




\begin{tabular}{|c|c|}
\hline & $\begin{array}{l}\text { "it’s hard and the reason I think it’s hard is because you don't } \\
\text { get it. You really just don't get it." }\end{array}$ \\
\hline \multirow[t]{2}{*}{ EBP should be modeled } & $\begin{array}{l}\text { "By example, primarily. I feel that professors and supervisors } \\
\text { should show examples when they do something - explain why } \\
\text { they're doing it and where the research exists" }\end{array}$ \\
\hline & $\begin{array}{l}\text { "if there's a question and they don't know it, say, "I don't know. } \\
\text { Let's look it up.”” }\end{array}$ \\
\hline \multirow[t]{2}{*}{ Need research skills } & $\begin{array}{l}\text { "it takes a while then one day it clicks. You're like 'oh, I can } \\
\text { read an article.”” }\end{array}$ \\
\hline & $\begin{array}{l}\text { "How to basically just separate the strong articles from the weak } \\
\text { articles and what makes you know, how many subjects makes a } \\
\text { good strong paper and what you know, uh, significant difference } \\
\text { - does it make a strong paper? And uh, just different - just break } \\
\text { it up completely into what makes a strong article." }\end{array}$ \\
\hline $\begin{array}{l}\text { Want research course related } \\
\text { to audiology }\end{array}$ & $\begin{array}{l}\text { "the statistics class, the EBP, if we could like have the stats class } \\
\text { that's more audiology oriented, you could go over some stuff } \\
\text { there." }\end{array}$ \\
\hline \multirow[t]{2}{*}{$\begin{array}{l}\text { Use research from courses to } \\
\text { learn EBP }\end{array}$} & $\begin{array}{l}\text { "I think somewhere in that year, there needs to be a way to } \\
\text { implement it into the classes of what they're teaching. Like all } \\
\text { those articles that they always give us, maybe actually have } \\
\text { assignments on them even though it’s more work, to make sure } \\
\text { you read them" }\end{array}$ \\
\hline & $\begin{array}{l}\text { "explained more than it is now. I think that rather than just } \\
\text { opening a book and showing, you know, this is what you do for } \\
\text { this sub-population, they should show that whoever found that } \\
\text { test to be beneficiary they should show you know, how they } \\
\text { found that to be. They should show the individuals that they had } \\
\text { tested before and the evidence from that." }\end{array}$ \\
\hline Want intro to technology & $\begin{array}{l}\text { "I think that that would be you know any sort of introduction to } \\
\text { technology would be the way to go as far as teaching evidence- } \\
\text { based practice." }\end{array}$ \\
\hline $\begin{array}{l}\text { Specifically in favor of the } \\
\text { Weblog }\end{array}$ & $\begin{array}{l}\text { "I think that the route to go truthfully in this day and age is the } \\
\text { Weblog." }\end{array}$ \\
\hline \multicolumn{2}{|c|}{$\begin{array}{l}\text { 3G. What recommendations would you have for our AuD program, regarding teaching evidence- } \\
\text { based practice? }\end{array}$} \\
\hline \multirow[t]{2}{*}{$\begin{array}{l}\text { Help students understand } \\
\text { research }\end{array}$} & $\begin{array}{l}\text { "We get them free as students - nobody knows how to read } \\
\text { those" }\end{array}$ \\
\hline & $\begin{array}{l}\text { "learning how to read articles and really knowing what they say } \\
\text { is important." }\end{array}$ \\
\hline
\end{tabular}




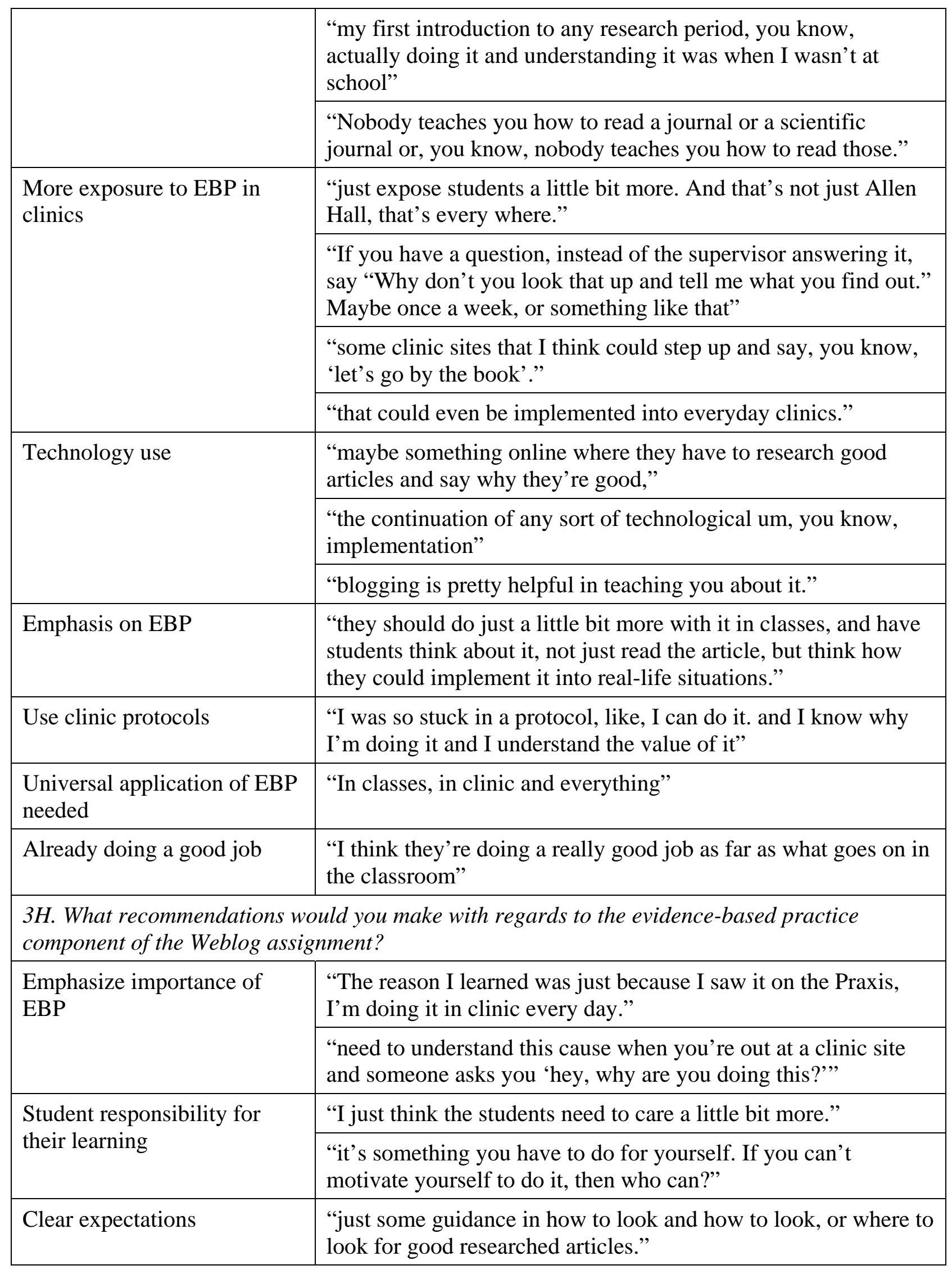




\begin{tabular}{|c|c|}
\hline & "Making specific minimum requirements for people to meet" \\
\hline \multicolumn{2}{|c|}{$\begin{array}{l}\text { 3I. Does/did more need to be done in your graduate courses to expose you to evidence-based } \\
\text { practice? }\end{array}$} \\
\hline \multirow[t]{4}{*}{ Emphasize reason for EBP } & $\begin{array}{l}\text { "I think if we knew that there was a reasoning behind what we } \\
\text { were doing and why we were mixing our personal experience } \\
\text { with research and some foundation to what we were doing" }\end{array}$ \\
\hline & $\begin{array}{l}\text { "any subject you take in an AuD program could always go into } \\
\text { more if you need to" }\end{array}$ \\
\hline & $\begin{array}{l}\text { "if you're in the middle of the medical field somewhere, you } \\
\text { better have it" }\end{array}$ \\
\hline & $\begin{array}{l}\text { "would have been a good thing to you know keep going when } \\
\text { we graduate so we would know what to do when we actually } \\
\text { had to do it on our own" }\end{array}$ \\
\hline \multirow[t]{2}{*}{ How to use in courses } & $\begin{array}{l}\text { "examples should be provided about how things were done for } \\
\text { many years and then were proved to be ineffective or there's a } \\
\text { better way to do it" }\end{array}$ \\
\hline & $\begin{array}{l}\text { "having us read more article and kind of figure out how to } \\
\text { implement it into clinic" }\end{array}$ \\
\hline Weblog assignment & $\begin{array}{l}\text { "the most that I heard about it and the most that I learned about } \\
\text { EBP was through the blogs." }\end{array}$ \\
\hline $\begin{array}{l}\text { Use term EBP in the } \\
\text { classroom }\end{array}$ & $\begin{array}{l}\text { "I think we were doing it but it wasn’t specifically being termed, } \\
\text { that phrase wasn’t being used.” }\end{array}$ \\
\hline Student responsibility & "I think students need to step up and do a little more” \\
\hline Already doing a good job & $\begin{array}{l}\text { "we read journal articles, and.... I think [instructor’s name] was } \\
\text { pretty good about that” }\end{array}$ \\
\hline \multicolumn{2}{|c|}{$\begin{array}{l}\text { 3J. Does/did more need to be done in your clinical practicum to expose you to evidence-based } \\
\text { practice? }\end{array}$} \\
\hline \multirow[t]{3}{*}{$\begin{array}{l}\text { Want more exposure in } \\
\text { clinical practicum }\end{array}$} & $\begin{array}{l}\text { "have more information and more supervisors stressing the } \\
\text { importance of it." }\end{array}$ \\
\hline & "it would be nice to be exposed to it a little bit more." \\
\hline & $\begin{array}{l}\text { "not how you do it, you know, per se, but you know, why you } \\
\text { would do this. I think that there was a little bit of a lag there." }\end{array}$ \\
\hline \multirow[t]{3}{*}{$\begin{array}{l}\text { Have observed evidence } \\
\text { ignored in clinic }\end{array}$} & $\begin{array}{l}\text { "When you fit a hearing aid on a child and you just use Best Fit } \\
\text { on the software, that's not EBP - that's trying to save time" }\end{array}$ \\
\hline & "a lot of people take short cuts sometimes." \\
\hline & $\begin{array}{l}\text { "some places could step up and say, you know, 'this is what } \\
\text { we're dong, this is why we're doing it."” }\end{array}$ \\
\hline
\end{tabular}




\begin{tabular}{|c|c|}
\hline \multirow[t]{3}{*}{ Want EBP modeled } & $\begin{array}{l}\text { "but they do it without involving us. We're just mainly there to } \\
\text { observe and help out and do the fundamentals. And it would be } \\
\text { nice to know what they do when we're not there" }\end{array}$ \\
\hline & $\begin{array}{l}\text { "I think they do it too - I would hope so - that they were } \\
\text { keeping up with information and keeping up with the journal } \\
\text { articles, and all the research." }\end{array}$ \\
\hline & $\begin{array}{l}\text { "some supervisors did stress the importance of you know, why } \\
\text { we do things" }\end{array}$ \\
\hline $\begin{array}{l}\text { Collaboration between } \\
\text { courses and clinic }\end{array}$ & $\begin{array}{l}\text { "I think at times it was just, um, to get us to understand only the } \\
\text { practical side of it and not correlating it back to our knowledge. } \\
\text { I think there was a little bit of a lag between those two." }\end{array}$ \\
\hline \multirow[t]{2}{*}{$\begin{array}{l}\text { Suggestions to in corporate } \\
\text { EBP in clinic }\end{array}$} & $\begin{array}{l}\text { "if there's a question, ask instead of just directly answering it. } \\
\text { Provide reasoning and be able to actually provide a source to go } \\
\text { to, to look up the reasoning in a printed format." }\end{array}$ \\
\hline & $\begin{array}{l}\text { "making a supervisor doing some and then the students doing } \\
\text { some research as well" }\end{array}$ \\
\hline $\begin{array}{l}\text { Need to be taught research } \\
\text { skills }\end{array}$ & $\begin{array}{l}\text { "Like where in the world do you find these full articles at? } \\
\text { Nobody tells you how to do that. Like, you don't know where to } \\
\text { get that stuff at." }\end{array}$ \\
\hline \multicolumn{2}{|c|}{ 3K. Is there anything else about evidence-based practice that you want to tell me? } \\
\hline \multirow[t]{4}{*}{$\begin{array}{l}\text { More exposure to EBP } \\
\text { needed }\end{array}$} & $\begin{array}{l}\text { "But when new things come out, I think you know, we could get } \\
\text { a copy of it, or be told this is where you need to go get it. And } \\
\text { actually be made to read it." }\end{array}$ \\
\hline & “there wasn't a huge amount of it in our schooling” \\
\hline & $\begin{array}{l}\text { "I definitely don't think we were as prepared as we needed to be } \\
\text { even when we were going off to do our fourth year" }\end{array}$ \\
\hline & "It’s a pain to read but it’s very helpful” \\
\hline \multirow[t]{3}{*}{ Need to see EBP modeled } & $\begin{array}{l}\text { "I had a good teacher when I left and was very patient with me } \\
\text { and literally took every second with me that I possible wanted to } \\
\text { help me get through everything" }\end{array}$ \\
\hline & $\begin{array}{l}\text { "everything was so focused on 'why do you do this?', 'why do } \\
\text { you do this?'”, }\end{array}$ \\
\hline & “they’re constantly doing research, constantly writing papers.” \\
\hline \multirow[t]{2}{*}{ Support application of EBP } & $\begin{array}{l}\text { "the journal articles and you sort of have to take that } \\
\text { information and combine it and figure out what would be best } \\
\text { for your patient." }\end{array}$ \\
\hline & $\begin{array}{l}\text { "So when they do graduate, they don't just leave with the } \\
\text { knowledge that they graduated with and not continue learning } \\
\text { and continuing researching things." }\end{array}$ \\
\hline
\end{tabular}




\begin{tabular}{|c|c|}
\hline \multirow[t]{2}{*}{ Resisted the work } & "I know a few that would never in a million years do that" \\
\hline & $\begin{array}{l}\text { "sometimes you gotta be forced to do what you don't want to } \\
\text { do." }\end{array}$ \\
\hline \multirow{2}{*}{$\begin{array}{l}\text { Suggestions for EBP blog } \\
\text { assignment }\end{array}$} & “it would be helpful to have, um, articles readily available.” \\
\hline & "make it a habit for the students to implement EBP” \\
\hline Research skills have develop & $\begin{array}{l}\text { "I attempt to still learn something every day. Today, I was } \\
\text { sitting reading all kinds of stuff" }\end{array}$ \\
\hline Positive aspect of blogs & "the blogs are a fun way to implement it." \\
\hline
\end{tabular}




\title{
Curriculum Vita
}

04/30/09

\author{
Gayle B. Neldon
}

Office:

Department of Speech Pathology and Audiology

Home:

807-E Allen Hall

PO BOX 6122

1009 Cobun Creek Road

West Virginia University

Morgantown, WV 26508

Phone: 304-291-0907

Morgantown, WV 26506-6122

Email: gneldon@gmail.com

Phone: 304-293-2687

Fax: 304-293-7565

Email: Gayle.Neldon@mail.wvu.edu

\section{Education}

A.B. (Speech Pathology), West Liberty State College, with honors

1977

M.S. (Audiology), West Virginia University

Credentials

Certificate of Clinical Competence in Audiology (CCC/A), American

1981- Present Speech-Language-Hearing Association

Licensed Audiologist, West Virginia Board of Examiners for Speech-

1994 - Present

Language Pathology and Audiology

\section{Professional Employment}

WVU Department of Speech Pathology and Audiology, Morgantown, WV

1999 - Present

Responsibilities:

Clinic Coordination for WVU Hearing Center, including:

- Co-administrator of Student Assessment Management System (SAMS) for WVU

- Entered all Au.D. student clinical competency data into SAMS

- Scheduling 11 Au.D. students for clinic placement in the AllenHall Hearing Center, the POC Hearing Clinc, and 5 off-campus practicum sites

- Scheduling 26 speech-language pathology graduate students for minor area practicum;

- Scheduling 46 seniors for senior audiology laboratory experience (SPA 483);

- Coordination of supervision for senior labs, Allen Hall Hearing Clinic, and screenings; 
- Scheduling of 36 graduate clinicians (SLP and Au.D.) for 12 hearing screenings:

- Revision of clinic packet for SPA 729 - 769;

- Coordination of HIPAA concerns and forms for clinic

- Coordination of hearing aid sales through Audiological Supply House;

- Coordination of hearing aid training, digital products, and software from the following manufacturers:

o Oticon - software, tools, and consignment instruments

o Phonak - software, tools, and consignment instruments

o Siemens - software, tools, and consignment instruments

o Starkey - software, tools, and consignment instruments

o Sonovation - software and tools

o Widex - software and tools

- Coordination of all hearing aid forms, including manufacturer-specific order forms, repair forms and return forms

- Coordination of HearNow program (service of Starkey Foundation to provide

hearing aids for individuals on limited incomes)

- Coordination of Oticon's University Program - organized site, meals, and continuing education offerings to local audiologists

o Two presentations, three speakers: George Lindley, AuD, Don Schum, PhD, and Randi Pogash, AuD

- Coordination of clinic equipment, including trouble shooting equipment problems, coordination of equipment calibration and maintenance of calibration records, seeking funding for new equipment

- Revision of audiology student clinician evaluation forms; Teaching responsibilities:

- SPA 391: Clinical Observation/Audiology (1 c.h.) Fall and Spring 1999 - Present Semesters

- SPA 440: Audiological Assessment (4 c.h.) Fall Semester

- SPA 483: Clinic Practice/Audiology (3 c.h.) Fall and Spring Semesters

- SPA 745: Seminar: Clinical Supervision (3 c.h.) Spring Semesters Clinic supervision for clinical practicum in Allen Hall Hearing Clinic:

- SPA 611: Advanced Clinic Practice/Audiology 1990 - Present

- SPA 729: Clinic 1 (Summer and Fall Semesters)

- SPA 739: Clinic 2 (Spring Semesters)

- SPA 749: Clinic 3 (Summer Semesters) 
Staff Audiologist, Audiology Associates of America, Fairmont, WV

$1989-1990$

Responsibilities included scheduling of clients, third party hearing

\& 1996 - 1999

evaluations, hearing aid evaluations, and hearing aid checks in two offices

affiliated with a local hearing aid business.

Clinical Audiologist, WVU Dept. of Otolaryngology, WVU Medical Center,

1989

Morgantown, WV

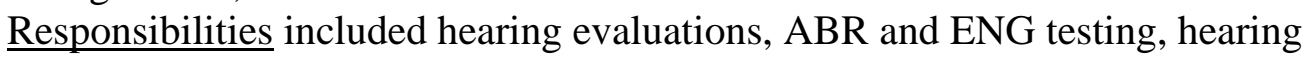

\& $1982-1983$

aid evaluations, supervision of WVU audiology graduate students, audiology

lectures to ENT residents, and industrial hearing testing.

\section{Publication}

Neldon, G. B. and Jones, R. R. Community noise awareness. Communique’, 1-6, 1992.

\section{Research}

Papers presented at ASHA Annual Convention, November, 2000:

- A Follow-Up on Hearing Aid Recommendations, Gayle B. Neldon and Robin R. Jones

- Use of Electronic Feedback in Clinical Supervision, Karen B. Haines, Lynn R. Cartwright, and Gayle B. Neldon

- An Instrument to Access Client Satisfaction in A University Clinic, Lynn R. Cartwright, Karen B. Haines, and Gayle B. Neldon

- Pre-service Students’ Perceptions of Interpersonal Skills, Lynn R. Cartwright and Gayle B. Neldon

\section{Professional Activities}

Current Professional Memberships:

- American Speech-Language-Hearing Association

- West Virginia Speech-Language-Hearing Association

- Association for Educational Communications and Technology

- International Society for Technology in Education

\section{Service}

Service to the Department of Speech Pathology and Audiology

Graduate Affairs Committee (Audiology)

2006 - Present

Member of committee, met monthly to address graduate student

issues, including admissions to WVU AuD program

Undergraduate Affairs Committee

2007 - Present

Member of committee, met periodically to address undergraduate student issues

Clinical Affairs Committee

1999 - Present

Member of committee, met periodically to address issues and

concerns

relating to the WVU Speech \& Hearing Center clinics 
HIPAA Committee 2005 - Present Member of committee - met multiple times to address compliance issues

Public Information / Outreach Committee 1999 - Present

Chair of committee - developed Department and Clinic brochures and

display board, send letters to parents of undergraduate majors.

Service to the College of Human Resources and Education

*Not eligible for College committees, due to my appointment title which is administrative and not faculty

\section{Service to West Virginia University}

Coordinated and supervised hearing screenings for MUSC200N: Recording $2000-2004$ Technology course, College of Creative Arts, Division of Music, former instructor: Tim Rhodes

Supervisor and liaison with WVU Department of Environmental Health and Safety regarding the WVU Hearing Conservation Program Supervise hearing screenings, WVU Student Health Fair, Towers

\section{Service to State and National Professional Organizations}

American Speech-Language-Hearing Association (ASHA) Audiology Advisory Committee, Elected to represent concerns of audiologists in WV to the National Association - 3 year term.

Responsibilities include:

Annual meeting in Washington, D.C. to address issues facing the profession Capitol Hill visits with WV Senators Aides and Representatives' Aides to address legislation affecting individuals with communication disorders

Review of policy drafts, advocacy concerns, and other issues to inform the ASHA Board of Directors (approximately 3 to 4 hours monthly Commitment. Electronic document review and discussion)

West Virginia Speech-Language-Hearing Association (WVSHA) Executive Board Elected Member, as American Speech-Language-Hearing Association 2008 - Present Audiology Advisory Committee member and liaison Responsibilities include:

Quarterly meetings to conduct the business of the Association

Relay issues and concerns from ASHA to WVSHA

West Virginia Speech-Language-Hearing Association (WVSHA) Executive 2008 - Present Board Elected Member, Vice President for Publications and Public Relationions (two terms) Responsibilities included:

Association semi-annual newsletter, including collecting news items, 
editing submissions, working with publisher Working with an effective Publications Committee Chairperson;

Association Public Relations Committee, including updating

Association Display Board and merchandise, worked with effective

Public Relations Committee Chairperson

Construction and Maintenance for WVSHA website (www.wvsha.org) $2001-2005$

West Virginia Speech-Language-Hearing Association (WVSHA) Audiology $1993-2000$

Affairs Committee - collaborated on convention meetings and speakers

Service to the Local Community and State of West Virginia

Supervised Hearing Screenings - various hearing screenings at the following: 1990 - 2008,

- Pleasant Day Care

- Preston County Headstart

- Central Elementary School

- Mountainview Rehabilitation Hospital

- Serendipity Pre-School

- Rock Forge Settlement House Health Fair

- Rock Forge Neighborhood House Health Fair,

- FCI-Morgantown Inmate Screenings

- FCI - Morgantown Staff and Family Health Fair

- METC Kids/Future Steps Pre-School

- WVU Nursery School

- Serendipity Pre-School

- St. Luke's Day Care

- Presbyterian Day Care

- Ruby Hospital Day Care

- Monongalia County Schools

Miscellaneous Training and Continuing Education

WVU College of Human Resources \& Education Faculty Academy

May, 2008, May, 2007,

May, 2005

Faculty Workshop on Teaching Clinical Amplification, sponsored by Oticon 2006

West Virginia Speech-Language-Hearing Association Annual Convention

$1998-2009$, $1990-1996$

West Virginia Speech-Language-Hearing Association Fall Audiology 2000 - 2007, Conferences

$1995-1998$

Multiple Hearing Aid Manufacturer Product Training, including:

1990 - 2009

- Oticon

- Siemens

- Unitron 
Gayle Neldon Curriculum Vita 152

- Widex

American Speech-Language-Hearing Association Annual Conventions

2000, 1988

Washington, DC, St. Louis, MO 